Cochrane Database of Systematic Reviews

\title{
Exercise interventions for smoking cessation (Review)
}

Ussher MH, Faulkner GEJ, Angus K, Hartmann-Boyce J, Taylor AH

Ussher MH, Faulkner GEJ, Angus K, Hartmann-Boyce J, Taylor AH.

Exercise interventions for smoking cessation.

Cochrane Database of Systematic Reviews 2019, Issue 10. Art. No.: CD002295.

DOI: 10.1002/14651858.CD002295.pub6.

www.cochranelibrary.com

Exercise interventions for smoking cessation (Review) 
TABLE OF CONTENTS

HEADER 1

ABSTRACT

PLAIN LANGUAGE SUMMARY

SUMMARY OF FINDINGS

BACKGROUND

OBJECTIVES

METHODS

RESULTS

Figure 1.

Figure 2.

DISCUSSION

Figure 3.

AUTHORS' CONCLUSIONS

ACKNOWLEDGEMENTS

REFERENCES

CHARACTERISTICS OF STUDIES

DATA AND ANALYSES

Analysis 1.1. Comparison 1 Exercise component versus smoking cessation programme only, Outcome 1 Smoking abstinence at longest follow-up, subgroup by exercise type.

Analysis 1.2. Comparison 1 Exercise component versus smoking cessation programme only, Outcome 2 Relapse prevention at longest follow-up.

WHAT'S NEW

HISTORY

CONTRIBUTIONS OF AUTHORS

DECLARATIONS OF INTEREST

SOURCES OF SUPPORT

DIFFERENCES BETWEEN PROTOCOL AND REVIEW

INDEX TERMS 
[Intervention Review]

\section{Exercise interventions for smoking cessation}

Michael H Ussher1,2, Guy E J Faulkner ${ }^{3}$, Kathryn Angus², Jamie Hartmann-Boyce ${ }^{4}$, Adrian H Taylor 5

1Population Health Research Institute, St George's, University of London, London, UK. 2Institute for Social Marketing, University of Stirling, Stirling, UK. ${ }^{3}$ School of Kinesiology, University of British Columbia, Vancouver, Canada. ${ }^{4}$ Nuffield Department of Primary Care Health Sciences, University of Oxford, Oxford, UK. 5 Faculty of Health: Medicine, Dentistry and Human Sciences, University of Plymouth, Plymouth, UK

Contact address: Michael H Ussher, Population Health Research Institute, St George's, University of London, Cranmer Terrace, London, SW17 0RE, UK. mussher@sgul.ac.uk.

Editorial group: Cochrane Tobacco Addiction Group

Publication status and date: New search for studies and content updated (no change to conclusions), published in Issue 10, 2019.

Citation: Ussher MH, Faulkner GEJ, Angus K, Hartmann-Boyce J, Taylor AH. Exercise interventions for smoking cessation. Cochrane Database of Systematic Reviews 2019, Issue 10. Art. No.: CD002295. DOI: 10.1002/14651858.CD002295.pub6.

Copyright @ 2019 The Cochrane Collaboration. Published by John Wiley \& Sons, Ltd.

\section{A B S T R A C T}

\section{Background}

Taking regular exercise, whether cardiovascular-type exercise or resistance exercise, may help people to give up smoking, particularly by reducing cigarette withdrawal symptoms and cravings, and by helping to manage weight gain.

\section{Objectives}

To determine the effectiveness of exercise-based interventions alone, or combined with a smoking cessation programme, for achieving long-term smoking cessation, compared with a smoking cessation intervention alone or other non-exercise intervention.

\section{Search methods}

We searched the Cochrane Tobacco Addiction Group Specialised Register for studies, using the term 'exercise' or 'physical activity' in the title, abstract or keywords. The date of the most recent search was May 2019.

\section{Selection criteria}

We included randomised controlled trials that compared an exercise programme alone, or an exercise programme as an adjunct to a cessation programme, with a cessation programme alone or another non-exercise control group. Trials were required to recruit smokers wishing to quit or recent quitters, to assess abstinence as an outcome and have follow-up of at least six months.

\section{Data collection and analysis}

We followed standard Cochrane methods. Smoking cessation was measured after at least six months, using the most rigorous definition available, on an intention-to-treat basis. We calculated risk ratios (RRs) and $95 \%$ confidence intervals (Cls) for smoking cessation for each study, where possible. We grouped eligible studies according to the type of comparison, as either smoking cessation or relapse prevention. We carried out meta-analyses where appropriate, using Mantel-Haenszel random-effects models.

\section{Main results}

We identified 24 eligible trials with a total of 7279 adult participants randomised. Two studies focused on relapse prevention among smokers who had recently stopped smoking, and the remaining 22 studies were concerned with smoking cessation for smokers who wished to quit. Eleven studies were with women only and one with men only. Most studies recruited fairly inactive people. Most of the trials employed supervised, group-based cardiovascular-type exercise supplemented by a home-based exercise programme and combined with a multi-session cognitive behavioural smoking cessation programme. The comparator in most cases was a multi-session cognitive behav- 
ioural smoking cessation programme alone. Overall, we judged two studies to be at low risk of bias, 11 at high risk of bias, and 11 at unclear risk of bias.

Among the 21 studies analysed, we found low-certainty evidence, limited by potential publication bias and by imprecision, comparing the effect of exercise plus smoking cessation support with smoking cessation support alone on smoking cessation outcomes (RR 1.08, 95\% $\mathrm{Cl} 0.96$ to $1.22 ; \mathrm{I}^{2}=0 \% ; 6607$ participants). We excluded one study from this analysis as smoking abstinence rates for the study groups were not reported. There was no evidence of subgroup differences according to the type of exercise promoted; the subgroups considered were: cardiovascular-type exercise alone (17 studies), resistance training alone (one study), combined cardiovascular-type and resistance exercise (one study) and type of exercise not specified (two studies). The results were not significantly altered when we excluded trials with high risk of bias, or those with special populations, or those where smoking cessation intervention support was not matched between the intervention and control arms. Among the two relapse prevention studies, we found very low-certainty evidence, limited by risk of bias and imprecision, that adding exercise to relapse prevention did not improve long-term abstinence compared with relapse prevention alone (RR $0.98,95 \% \mathrm{Cl} 0.65$ to $1.47 ; 1^{2}=0 \%$; 453 participants).

\section{Authors' conclusions}

There is no evidence that adding exercise to smoking cessation support improves abstinence compared with support alone, but the evidence is insufficient to assess whether there is a modest benefit. Estimates of treatment effect were of low or very low certainty, because of concerns about bias in the trials, imprecision and publication bias. Consequently, future trials may change these conclusions.

\section{PLAIN LANGUAGE SUMMARY}

\section{Can exercise help people quit smoking?}

\section{Background}

We reviewed the evidence about whether exercise helps people who want to quit smoking, or have recently stopped smoking, to stop smoking for at least six months. Taking regular exercise may help people give up smoking by helping with cigarette withdrawal and cravings, and by helping them to manage weight gain, which can be a concern among people trying to quit.

\section{Study characteristics}

We found 24 studies with a total of 7279 people. Two studies focused on helping those who had recently stopped smoking and the rest of the studies included current smokers who wished to quit. All the studies were conducted with adults. Eleven studies were with women only and one with men only. Most studies recruited fairly inactive people. Most studies offered supervised and group-based, aerobic-type exercise. The evidence is up-to-date to May 2019.

\section{Key results}

When we combined the results of 21 studies (6607 participants) which compared exercise and smoking-cessation programmes to smoking cessation programmes alone, there was no evidence that exercise increased quit rates at six months or longer. There was no evidence that the effect was different for different types of exercise. When we combined results from two studies (453 participants), there was no evidence that exercise helped people who had recently quit to stay quit.

\section{Quality of evidence}

We judged the quality of evidence for whether exercise programmes help people quit smoking as low certainty, suggesting that future research could change these results. The low certainty is because we cannot rule out chance as an explanation for the suggested slight benefit. It could be that exercise may not help at all, or it could be that supporting people to do exercise modestly increases quit rates. We do not know which of these is true. We also consider that a good number of the trials may be biased. We have concerns that small studies which found smaller effects were less likely to be published than small studies which found bigger effects, making the average result misleading. We judged the evidence from two studies examining whether exercise helps people to avoid relapse to smoking to be of very low certainty, again suggesting that more research is needed. This is due to imprecision of the estimated effects and a high risk of bias in the methods used by one of the studies. 


\begin{tabular}{|c|c|c|c|c|c|c|}
\hline Summary of findings for the main cor & arison. Exe & ise interventions for sn & oking cessatic & & & \\
\hline \multicolumn{7}{|c|}{ Exercise interventions for smoking cessation } \\
\hline \multicolumn{7}{|c|}{$\begin{array}{l}\text { Patient or population: People who smoke or who have recently quit } \\
\text { Setting: Community and healthcare settings in Canada, Finland, France, New Zealand, UK, USA } \\
\text { Intervention: Exercise and smoking cessation support or exercise alone } \\
\text { Comparison: Smoking cessation support only }\end{array}$} \\
\hline \multirow[t]{2}{*}{ Outcomes } & \multicolumn{2}{|c|}{ Anticipated absolute effects ${ }^{\star}(95 \% \mathrm{Cl})$} & \multirow{2}{*}{$\begin{array}{l}\text { Relative ef- } \\
\text { fect } \\
(95 \% \mathrm{CI})\end{array}$} & \multirow{2}{*}{$\begin{array}{l}\text { № of partici- } \\
\text { pants } \\
\text { (studies) }\end{array}$} & \multirow{2}{*}{$\begin{array}{l}\text { Certainty of } \\
\text { the evidence } \\
\text { (GRADE) }\end{array}$} & \multirow[t]{2}{*}{ Comments } \\
\hline & $\begin{array}{l}\text { Risk with } \\
\text { smoking ces- } \\
\text { sation sup- } \\
\text { port only }\end{array}$ & $\begin{array}{l}\text { Risk with Exercise pro- } \\
\text { gramme and smoking } \\
\text { cessation support or } \\
\text { exercise programme } \\
\text { alone }\end{array}$ & & & & \\
\hline \multirow{2}{*}{$\begin{array}{l}\text { Smoking abstinence at longest follow-up } \\
\text { assessed with: self-report and biochemi- } \\
\text { cal validation } \\
\text { Follow-up: range } 6 \text { months to } 16 \text { months }\end{array}$} & \multicolumn{2}{|c|}{ Study population } & \multirow{2}{*}{$\begin{array}{l}\text { RR } 1.08 \\
\text { (0.96 to } 1.22 \text { ) }\end{array}$} & \multirow{2}{*}{$\begin{array}{l}6607 \\
\text { (21 RCTs) }\end{array}$} & \multirow{2}{*}{$\begin{array}{l}\oplus \oplus \odot \odot \\
\text { LOWa,b,c }\end{array}$} & \multirow[b]{2}{*}{$\begin{array}{l}\text { Results were not sensitive } \\
\text { to the removal of } 2 \text { studies } \\
\text { where cessation support } \\
\text { was not matched between } \\
\text { arms (e.g. potential risk of } \\
\text { confounding), nor were they } \\
\text { sensitive to the removal of } \\
\text { the } 6 \text { studies in special pop- } \\
\text { ulation groups. In one of } \\
\text { these studies, the interven- } \\
\text { tion group was not provided } \\
\text { with smoking cessation sup- } \\
\text { port }\end{array}$} \\
\hline & 126 per 1000 & $\begin{array}{l}136 \text { per } 1000 \\
(121 \text { to } 153)\end{array}$ & & & & \\
\hline \multirow{2}{*}{$\begin{array}{l}\text { Relapse prevention at longest follow-up } \\
\text { assessed with: Self-report and biochemi- } \\
\text { cal validation } \\
\text { Follow-up: range } 6 \text { months to } 12 \text { months }\end{array}$} & \multicolumn{2}{|c|}{ Study population } & \multirow{2}{*}{$\begin{array}{l}\text { RR } 0.98 \\
\text { (0.65 to } 1.47 \text { ) }\end{array}$} & \multirow{2}{*}{$\begin{array}{l}453 \\
\text { (2 RCTs) }\end{array}$} & \multirow{2}{*}{$\begin{array}{l}\oplus \odot \odot \odot \\
\text { VERY LOWd,e }\end{array}$} & \multirow[t]{2}{*}{-} \\
\hline & 164 per 1000 & $\begin{array}{l}160 \text { per } 1000 \\
(106 \text { to } 240)\end{array}$ & & & & \\
\hline
\end{tabular}

*The risk in the intervention group (and its $95 \%$ confidence interval) is based on the assumed risk in the comparison group and the relative effect of the intervention (and its $95 \% \mathrm{Cl}$ ). The assumed risk in the comparison group is a weighted average of the quit rates of the control arms in the included studies.

Cl: Confidence interval; RR: Risk ratio

GRADE Working Group grades of evidence 
High certainty: We are very confident that the true effect lies close to that of the estimate of the effect

Moderate certainty: We are moderately confident in the effect estimate: The true effect is likely to be close to the estimate of the effect, but there is a possibility that it is substantially different

Low certainty: Our confidence in the effect estimate is limited: The true effect may be substantially different from the estimate of the effect

Very low certainty: We have very little confidence in the effect estimate: The true effect is likely to be substantially different from the estimate of the effect

a Not downgraded on risk of bias. Sensitivity analysis excluding 10 studies judged to be at high risk of bias was consistent with overall effect, although point estimate showed an increase in favour of intervention (RR $1.25,95 \% \mathrm{Cl} 0.99$ to 1.58 ).

bDowngraded by one level due to imprecision. Confidence interval spans no effect as well as clinically significant benefit.

'Downgraded by one level due to suspected publication bias. Assymetrical funnel plot (see Figure 3) suggests smaller studies showing larger effects were more likely to be

published than smaller studies showing smaller effects.

dDowngraded by one level due to risk of bias. We judged the larger of the two contributing studies to be at high risk of bias.

eDowngraded by two levels due to imprecision. Confidence interval spans clinically significant harm as well as clinically significant benefit. 


\section{B A C K G R O U N D}

\section{Description of the condition}

Tobacco use is a leading cause of preventable illness and death worldwide, accounting for over seven million deaths annually (GBD 2015 Risk Factors Collaborators 2016). Based on current smoking trends, there will be approximately 400 million tobacco-related deaths between 2010 and 2050, mostly among current smokers (Jha 2011). Most smokers would like to stop (CDC 2017); however, quitting is difficult and there is a need to develop more effective interventions.

\section{Description of the intervention}

In this review, the exercise interventions focus on more formal, structured activities, such as using a stationary cycle, although some of the interventions promote 'lifestyle' activities, such as walking. Mode of exercise tends to be described as either predominantly cardiovascular (e.g. walking, stationary cycling), where there is an emphasis on improving cardiovascular fitness, or resistance-based (e.g. weight training), where the emphasis is on developing strength. Some interventions combine cardiovascular and resistance training, while others focus on one or the other.

Besides having the potential to help individuals to stop smoking and to avoid relapse, exercise interventions have the bonus that, if regular exercise is maintained, they have many general health benefits. These benefits have been observed for the general population as well as for people who quit smoking (Albrecht 1998; Korhonen 2011; Shinton 1997) and for people who continue to smoke (Colbert 2001; Hedblad 1997; Senti 2001), and exercise meets the principles of a tobacco harm-reduction strategy (De Ruiter 2006). For example, physical activity has been negatively associated with lung carcinoma among current and former smokers (Leitzmann 2009) and has been found to reduce oxidative stress in smokers (Koubaa 2015). Also, smokers who adhere to physical activity guidelines show a significant reduction in mortality (Siahpush 2019). In the general population, researchers have shown that regular exercise has benefits for mental health, such as reducing symptoms of depression (Cooney 2013). Smokers who exercise more have been found to have less depression (Vickers 2003; Williams 2008) and exercise has been found to moderate the association between nicotine dependence and depression (Loprinzi 2014).

Smokers trying to quit are attracted to a more physically active lifestyle (Doherty 1998; King 1996), although most smokers are unlikely to spontaneously increase their levels of physical activity after quitting (Allen 2004; Hall 1989; Vander Weg 2001). Being physically active has been positively associated with intention to quit (Frith 2017), initiating a quit attempt (Deruiter 2008; Gauthier 2012; Haddock 2000), with confidence in maintaining smoking abstinence (King 1996) and with success at stopping smoking (Abrantes 2009; Derby 1994; Loprinzi 2016; Paavola 2001; Sedgwick 1988). Among smokers who are not ready to quit, participation in regular physical activity has been associated with reduced cigarette cravings (Haasova 2016). Other work shows a positive trend between avoiding relapse to smoking and physical health and fitness (Metheny 1998), and among those who are more physically active there is evidence for a reduced risk of smoking relapse (LópezTorrecillas 2014; McDermot 2009).

\section{How the intervention might work}

Most of the evidence exploring mechanisms for how exercise might aid smoking cessation comes from experimental studies, examining the acute effects of exercise, although it is argued that most of these mechanisms could also apply to long-term exercise, involving regular bouts of exercise. In experimental studies, temporarily abstinent smokers have consistently been shown to have reduced psychological withdrawal symptoms and desire to smoke following a bout of cardiovascular-type exercise (Haasova 2013; Haasova 2014; Roberts 2012; Taylor 2007b). Studies with longer bouts of exercise tended to show a more sustained effect on reducing cravings and withdrawal, and further research is needed to understand how exercise dose impacts on the duration of acute effects. However, even brief bouts of exercise, with a brief effect, may work to help abstinent smokers cope with a temporary spike in cravings. Besides exercise potentially helping smokers by reducing self-reported withdrawal and cravings, several studies have shown that a bout of exercise delays smoking or favourably influences smoking topography, possibly mediated through reduced cravings and withdrawal (De Jesus 2018b; Faulkner 2010; Hatzigeorgiadis 2016; Katomeri 2007; Kurti 2014a; Mikhail 1983; Reeser 1983; Taylor 2007a; Thayer 1993).

The mechanisms underlying these acute beneficial effects of exercise are not clear. Exercise has some similarities to smoking in its effects on stimulating the central nervous system (Russell 1983) and on neurobiological processes (Dishman 2009), including increasing beta-endorphin levels in smokers (Leelarungrayub 2010), and may provide an alternative reinforcer to smoking; there is evidence that this may also depend on the reinforcing value of physical activity versus smoking for particular individuals (Audrain-McGovern 2015). It is plausible that attention to somatic cues (e.g. bodily sensations and movements) during exercise could distract smokers from cravings, although one study showed distraction is unlikely to play a major role (Daniel 2006). There is also some evidence that exercise might work by reducing attentional bias to smoking-related cues that trigger cravings (Janse van Rensburg 2009a; Oh 2014).

Haasova 2014 used an individual participant data meta-analysis to examine a range of demographic, smoking and other characteristics as potential moderators of the acute effect of exercise on desire to smoke, and examined change in affect as a mediator. None of the characteristics examined were shown to moderate or mediate the effects of exercise. However, it is worth considering the studies in this review, and other studies, which have examined the mediators and moderators of the effects of exercise on smoking-related outcomes. For example, some studies have examined whether expectancy about the likely effects of exercise influence the effects of exercise; in one study exercise expectancy was modestly associated with psychological symptoms, but not with cigarette craving (Harper 2013), and in another study expectancy did not explain any of the effects of exercise (Daniel 2007). As regards physiological mechanisms, studies have investigated whether exercise might work by overcoming lowered cortisol levels experienced during smoking abstinence (Steptoe 2006); in four studies changes in cortisol concentration were unrelated to changes in cravings (De Jesus 2018a; Janse van Rensburg 2013; Roberts 2015; Scerbo 2010), suggesting that cortisol changes do not mediate the effects of exercise on cravings. Additionally, one study showed that changes in plasma noradrenaline may mediate the effect of exercise on cravings, although heart rate variability was not found to mediate this effect 
(Roberts 2015). It has been hypothesised that fitness improvements may be beneficial among those attempting to stop smoking (Marcus 1991); however, exercise has the potential to aid cessation without changes in physical capacity, as shown by the above literature on the acute effects of brief bouts of exercise on reducing cigarette cravings.

Taylor 2006a observed that acute reductions in urges to smoke in response to exercise were mediated by reductions in tension. Three studies involving functional magnetic resonance imaging showed that parts of the brain that are typically activated by smoking cues (images) were less activated following a bout of moderate-intensity exercise (Janse van Rensburg 2009b; Janse van Rensburg 2010; Janse van Rensburg 2012). There is also evidence to suggest that an exercise intervention might work to benefit smokers who are trying to stop smoking by reducing post-smoking cessation weight gain (Farley 2012), and by reducing cravings for sweet foods (Oh 2014; Teo 2014). Other evidence suggests that regular exercise may facilitate smoking cessation through exercise-induced increases in smoking-specific self-efficacy (Loprinzi 2015) or through fostering a physically active identity (Glowaski 2018; Verkooijen 2008; Taylor 2014). Finally, one methodologically rigorous study has shown that an exercise intervention may be effective for helping smokers to reduce their cigarette consumption (Taylor 2014), although several less rigorous studies did not find any benefit for exercise in reducing cigarette consumption (Bernard 2013; Gorini 2012; Kovelis 2012; Leelarungrayub 2010; McClure 2011; Whiteley 2007; Ybarra 2013).

\section{Why it is important to do this review}

There is evidence from large cross-sectional surveys that levels of physical activity are inversely related to smoking rates, both among adults (Boutelle 2000; Boyle 2000; Hu 2002; Picavet 2010; Schuman 2001; Swan 2018; Takemura 2000) and among adolescents (Aaron 1995; Ali 2015; Coulson 1997; Escobedo 1993; Pate 1996; Peretti-Watel 2002; Rodriguez 2004; Rodriguez 2008; Verkooijen 2008; Ward 2003). A review of studies examining associations between smoking and physical activity has been published by Kaczynski 2008. However, a review of randomised controlled trials is needed to establish whether these associations are causal. This review of exercise interventions for smoking cessation was first published in 2000, in Addiction (Ussher 2000a), and was converted into a Cochrane Review the same year (Ussher 2000b). Since our last update in 2014, we have become aware of new trials that needed to be considered for inclusion. Furthermore, the Cochrane Tobacco Addiction Group editorial team suggested incorporating a meta-analysis and other improvements. The aim of this review is therefore to update the evidence in this area, using improved methods.

\section{O B J E C T IVES}

To determine the effectiveness of exercise-based interventions alone, or combined with a smoking cessation programme, for achieving long-term smoking cessation, compared with a smoking cessation intervention alone or other non-exercise intervention.

\section{METHODS}

\section{Criteria for considering studies for this review}

\section{Types of studies}

Randomised controlled trials (RCTs) and cluster-RCTs.

\section{Types of participants}

Tobacco smokers wishing to quit, or recent quitters.

\section{Types of interventions}

Interventions aimed at increasing exercise, either alone or as an adjunct to a smoking cessation intervention, compared with a smoking cessation programme alone or another type of non-exercise control group. We excluded interventions which included exercise in a multiple-component programme, since the specific effects of exercise on smoking abstinence could not be addressed. We therefore excluded yoga-based interventions, which involved a combination of exercise, meditation and breathing exercises.

\section{Types of outcome measures}

Our primary outcome was smoking cessation at the longest follow-up reported. We excluded trials with less than six months' follow-up. Where multiple measures of cessation were reported, we preferred continuous/prolonged cessation over point prevalence cessation, and biochemically validated over self-reported cessation.

As discussed in the Background section, it is postulated that exercise might aid smoking cessation through a range of mechanisms, including effects on tobacco cravings, withdrawal symptoms, or other psychological symptoms, or effects on fitness or physiological or cognitive processes, as well as effects on weight/body mass index (BMI) and reductions in cigarette consumption; we therefore considered any potential mechanisms of action that were examined in the studies.

\section{Search methods for identification of studies}

We searched the Cochrane Tobacco Addiction Group Specialised Register in May 2019 for reports of studies including the terms 'exercise' or 'physical activity' in the title, abstract or keywords. The Register has been developed from electronic searching of the Cochrane Central Register of Controlled trials (CENTRAL), MEDLINE, Embase and PsycINFO, together with handsearching of specialist journals, conference proceedings and reference lists of previous trials and overviews. For details of the searches used to create the Specialised Register see the Cochrane Tobacco Addiction Group Website. At the time of the Register search, results from the following databases were included:

- Cochrane Central Register of Controlled trials (CENTRAL), issue 1, 2018;

- MEDLINE (via OVID) to update 20190409;

- Embase (via OVID) to week 201915;

- PsycINFO (via OVID) to update 20190401.

We also searched CINAHL, and Web of Science Indices (SCI-EXPAND$\mathrm{ED}, \mathrm{SSCl}, \mathrm{A \& HCl}, \mathrm{CPCl}-\mathrm{S}, \mathrm{CPCl}-\mathrm{SSH}, \mathrm{BKCl}-\mathrm{S}, \mathrm{BKCl}-\mathrm{SSH}, \mathrm{ESCl})$ using the terms 'smoking', 'smoking cessation', 'exercise', 'physical activity', and 'intervention' (searches completed 26 April 2019), and carried out a handsearch of reference lists, conducted searches on key authors, and contacted key authors. In addition, we searched the following online trial registries to identify unpublished studies: ClinicalTrials.gov and the International Clinical Trials Registry Platform (ICTRP). 


\section{Data collection and analysis}

\section{Selection of studies}

Two review authors (from MU, AT, GF, KA) independently screened the title and abstract of each record returned for eligibility. Where there was uncertainty, we put the record forward to the next round of screening. We then retrieved the full-text reports of any trials considered potentially relevant. Two review authors (from MU, AT, GF, KA) independently assessed the full texts for inclusion, and referred any disagreements to a third review author.

\section{Data extraction and management}

Two review authors (from MU, AT, GF, KA) independently extracted the following information about each eligible trial, where available: - Details of study design, including methods of randomisation and recruitment;

- Participant characteristics, e.g. demographic descriptors (age, sex, ethnicity), cigarette consumption, exercise levels at entry, preexisting conditions;

- Description of the exercise intervention(s), including the nature, frequency and duration of exercise;

- Description of comparator(s)/control(s), including the nature, frequency and duration of the smoking cessation programme;

- Rates of exercise adherence and use of techniques to support exercise adherence;

- Primary outcome measures: definition of smoking cessation used for primary outcome, timing of longest follow-up, any biochemical validation;

- Secondary outcome measures: cigarette consumption, craving and withdrawal symptoms and other psychological symptoms, fitness, BMI and body weight;

- Loss to follow-up;

- Funding source;

- Declarations of interest.

We then compared and amalgamated extraction for each study, with any disagreements referred to a third review author.

\section{Assessment of risk of bias in included studies}

In accordance with the Cochrane guidelines for clinical trials (Higgins 2011; Higgins 2017) and using the Cochrane 'Risk of bias' tool, we assessed studies for risk of selection bias (random sequence generation and allocation sequence concealment), detection bias (blinding of outcome assessment), attrition bias (incomplete outcome data), reporting bias (selective outcome reporting) and other potential sources of bias. Following the standard methods of the Cochrane Tobacco Addiction Group, we rated studies at high risk of detection bias if smoking cessation was not biochemically validated (as the nature of these studies precludes blinding of participants, and in the case of self-report the participant is the outcome assessor), and at low risk if biochemical validation was used. We did not assess the performance bias domain (blinding of participants and personnel), as blinding of participants and personnel is not feasible due to the nature of the intervention; this domain would not allow us to discriminate between how well the studies were conducted. Two review authors (from MU, AT, GF, KA) independently rated each domain as being at high, low or unclear risk of bias, for each study. We resolved any disagreements through discussion with a third review author. Overall, we considered studies to be at high risk of bias if we rated them at high risk in one or more domains, at low risk if we judged all domains to be at low risk, and at unclear risk otherwise.

\section{Measures of treatment effect}

For our primary outcome, we extracted the most stringent definition of smoking cessation for each study (i.e. longest follow-up, continuous/prolonged versus point prevalence, and biochemically validated versus self-report). Where possible, we expressed trial effects as a risk ratio (RR), calculated as: (quitters in treatment group/ total randomised to treatment group)/(quitters in control group/ total randomised to control group), with a 95\% confidence interval $(\mathrm{Cl})$. A risk ratio greater than 1 indicates a potentially better outcome in the intervention group than in the control group. Potential mechanisms of action (cigarette consumption, craving and withdrawal symptoms and other psychological symptoms, fitness, BMI and body weight) were discussed narratively.

\section{Unit of analysis issues}

We considered both individually- and cluster-randomised trials. We deemed no cluster-randomised trials to be eligible for inclusion.

\section{Dealing with missing data}

We conducted our analyses on an intention-to-treat basis, i.e. using all participants randomised to their original groups as denominators where data were available, and assuming that those lost to follow-up were continuing to smoke (West 2005). We extracted numbers lost to follow-up from study reports and used these to assess the risk of attrition bias. Where any required primary outcome data were not available in study reports, we contacted the authors in an attempt to obtain them.

\section{Assessment of heterogeneity}

Before pooling studies, we considered both methodological and clinical variance between studies. Where pooling was deemed appropriate, we investigated statistical heterogeneity using the $\mathrm{I}^{2}$ statistic (Higgins 2003). This describes the percentage of the variability in effect estimates that is due to heterogeneity rather than to sampling error (chance).

\section{Assessment of reporting biases}

We used a funnel plot to assess small-study effects and investigate the possibility of publication bias for the 'exercise versus other smoking cessation treatment' comparisons. There were not enough studies (fewer than 10) included in the analysis for relapse prevention studies to create a funnel plot.

\section{Data synthesis}

For our primary outcome of smoking cessation, we synthesised groups of studies using Mantel-Haenszel random-effects models to estimate separate pooled treatment effects (as RRs and 95\% Cls), for two types of comparison:

- Effects of exercise versus no exercise intervention, on smoking cessation outcomes (comparison 1, i.e. aimed at current smokers wishing to quit smoking);

- Effects of exercise versus no exercise intervention, on relapse prevention outcomes (comparison 2, i.e. aimed at recent quitters). 


\section{Subgroup analysis and investigation of heterogeneity}

In view of possible heterogeneity between studies, where relevant and if there were sufficient studies we analysed the trials in subgroups stratified by the type of exercise.

\section{Sensitivity analysis}

We carried out the following sensitivity analyses to see if the pooled results of analyses were sensitive to the removal of:

- Studies judged to be at high risk of bias;

- Studies with special populations;

- Studies where the smoking cessation support was not matched between the intervention and control groups.

\section{'Summary of findings' table}

Following standard Cochrane methodology (Schünemann 2017), we created a 'Summary of findings' table for the comparison of the effects of exercise versus no exercise intervention on outcomes for smoking cessation and for relapse prevention.
We used the five GRADE considerations (study limitations, consistency of effect, imprecision, indirectness and publication bias) to assess the certainty of the body of evidence for exercise aiding smoking cessation or relapse prevention, and to draw conclusions about the certainty of the evidence within the text of the review.

\section{RES U L T S}

\section{Description of studies}

See Characteristics of included studies; Characteristics of excluded studies; and Characteristics of ongoing studies tables for details of studies.

\section{Results of the search}

Our most recent search produced 1957 records. After duplicates were removed, we screened 1772 records for title and abstract. At this stage, we excluded 1705 records, and screened the full text for 67 records. We identified six completed studies and four ongoing studies, and excluded 57 studies. See Figure 1 for the PRISMA flow diagram. 
Figure 1. Study flow diagram for 2019 update

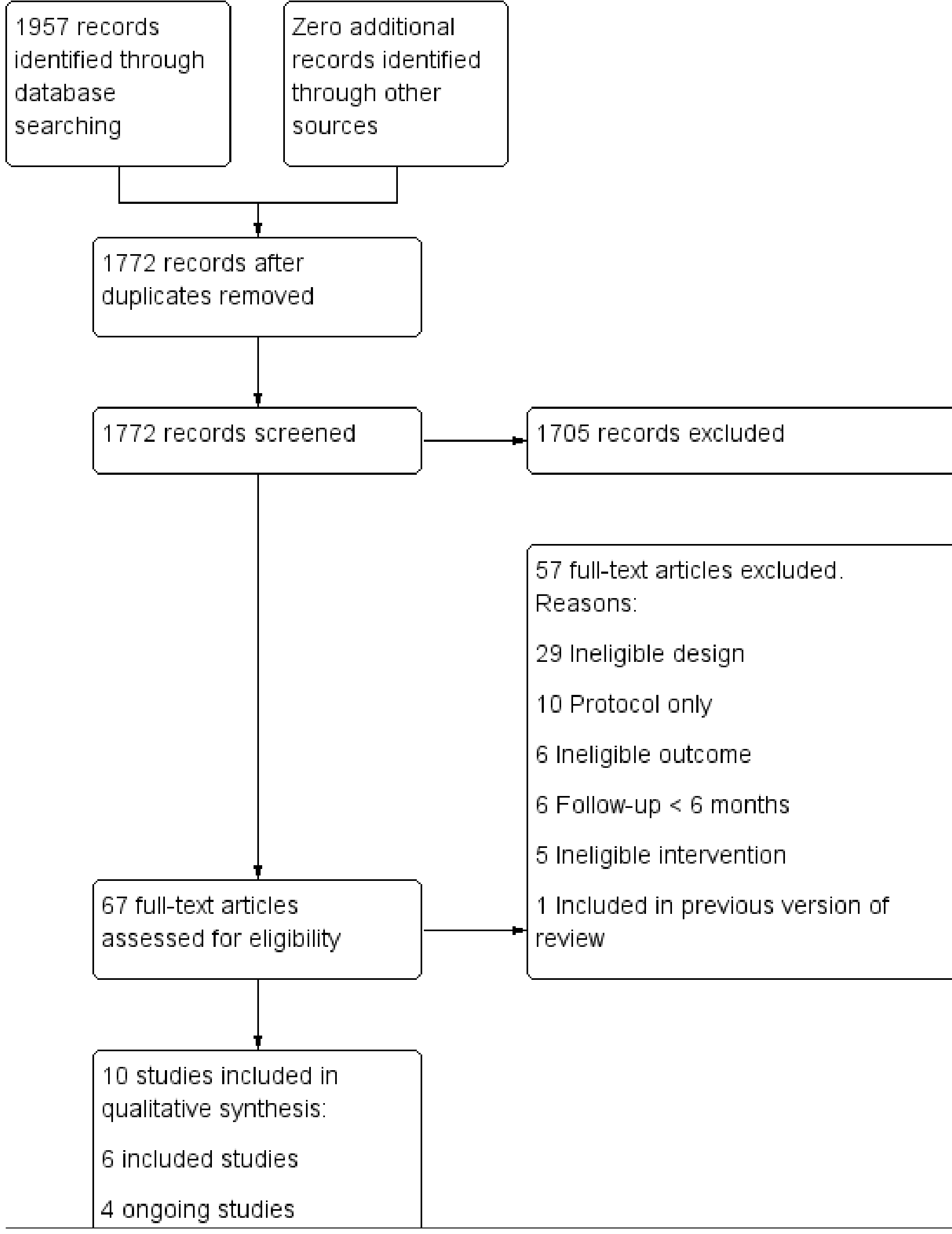

Exercise interventions for smoking cessation (Review) 


\section{Included studies}

This review includes 24 individually-randomised RCTs. We have added six studies since the last version of this review (Bernard 2015; Hassandra 2017; Patten 2017; Prapavessis 2016; Smits 2016; Ussher 2015). We now exclude two studies from the last version of the review, as we decided that they did not meet the inclusion criteria: one was a multi-component yoga intervention, in which the independent effects of exercise could not be examined (Bock 2012), while the other included some participants who did not wish to stop smoking (Horn 2011). Fourteen studies had more than one associated publication or abstract and these are listed under their study identifier in the reference section.

Two trials were conducted in France (Bernard 2015; Bize 2010), two in New Zealand (Maddison 2014; Prapavessis 2007), two in the UK (Ussher 2003; Ussher 2015), one in Finland (Hassandra 2017), 15 in the USA (Abrantes 2014; Ciccolo 2011; Hill 1993; Kinnunen 2008; Marcus 1991; Marcus 1995; Marcus 1999; Marcus 2005; Martin 1997; McKay 2008; Patten 2017; Russell 1988; Smits 2016; Taylor 1988; Whiteley 2012) and two in Canada (Hill 1985; Prapavessis 2016).

\section{Participants}

There was a total of 7279 participants randomised in the included studies, the largest study being an Internet trial with 2318 participants (McKay 2008). Nine trials had fewer than 30 individuals in each treatment arm (Ciccolo 2011; Hassandra 2017; Hill 1985; Hill 1993; Marcus 1991; Marcus 1995; Patten 2017; Russell 1988; Taylor 1988) and three of these were described as pilot or feasibility studies (Ciccolo 2011; Hassandra 2017; Patten 2017). Only nine studies had a sufficiently large sample size to have a good prospect of detecting treatment effects (Bize 2010; Maddison 2014; Marcus 1999; Marcus 2005; Martin 1997; McKay 2008; Prapavessis 2016; Ussher 2003; Ussher 2015).Two studies focused on relapse prevention and recruited those who had recently attempted to stop smoking (Hassandra 2017; Prapavessis 2016); the remaining studies randomised current smokers who wished to quit. Six studies recruited from special populations: one trial recruited people with post-acute myocardial infarction (AMI) (Taylor 1988); another targeted pregnant smokers (Ussher 2015); two recruited individuals with symptoms reflecting moderate to severe depression (Bernard 2015; Patten 2017); one study involved those with high levels of anxiety sensitivity (Smits 2016); and one was among those recovering from alcohol dependence (Martin 1997). The remaining trials recruited from the general population of smokers.

Eleven trials were limited to women (Kinnunen 2008; Marcus 1991; Marcus 1995; Marcus 1999; Marcus 2005; Patten 2017; Prapavessis 2007; Prapavessis 2016; Russell 1988; Ussher 2015; Whiteley 2012) and one was restricted to men (Taylor 1988). Sixteen studies recorded ethnic status, and all reported a predominantly white sample. Six studies did not present the participants' level of exercise at baseline (Abrantes 2014; Ciccolo 2011; Hill 1985; McKay 2008; Russell 1988; Taylor 1988). All the remaining studies, except Hassandra 2017 and Ussher 2015, reported that they had recruited fairly sedentary participants.

\section{Exercise interventions}

Most of the trials used supervised, group-based cardiovascular-type exercise supplemented by a home-based programme, but with some deviation from this formula. Five studies did not pro- vide a home programme (Ciccolo 2011; Marcus 1991; Marcus 1995; Marcus 1999; Smits 2016). Ciccolo 2011 focused exclusively on an individual programme of resistance exercise (i.e. weight training). Whiteley 2012 offered both supervised cardiovascular exercise and resistance exercise. One study used only brief one-to-one counselling towards pursuing home-based exercise, with the type of exercise not specified (Ussher 2003); one focused on telephone-based counselling towards cardiovascular-type exercise (Maddison 2014); one provided a web-based programme designed to encourage engagement in a personalised fitness programme (McKay 2008), although a description of the type of exercise promoted was not provided; and another study focused on providing an app, with brief face-to-face instruction, which encouraged short bouts of various types of exercise to manage cigarette cravings (Hassandra 2017).

Only five of the studies promoted exercise as a coping strategy for managing cigarette cravings (Bernard 2015; Hassandra 2017; Patten 2017; Ussher 2003; Ussher 2015). One study promoted exercise as an "opportunity to reestablish a sense of safety around intense bodily sensations" (Smits 2016).

Sixteen studies began the exercise programme before the quit date (Abrantes 2014; Bernard 2015; Bize 2010; Hill 1993; Kinnunen 2008; Marcus 1991; Marcus 1995; Marcus 1999; Marcus 2005; Patten 2017; Prapavessis 2007; Prapavessis 2016; Smits 2016; Ussher 2003; Ussher 2015; Whiteley 2012), three on the quit date (Ciccolo 2011; Hill 1985; Martin 1997), and four after the quit date (Hassandra 2017; Maddison 2014; Russell 1988; Taylor 1988). One study did not state the timing of the exercise programme relative to quit date (McKay 2008).

In Marcus 2005, among participants in the exercise group, those with higher adherence to the exercise prescription were significantly more likely to achieve smoking cessation at the end of treatment than were participants reporting lower adherence to exercise. During the treatment period, researchers used a range of behaviour change techniques to improve adherence to the exercise programme. All the studies included goal-setting, 14 used self-monitoring (Abrantes 2014; Bernard 2015; Hassandra 2017; Hill 1985; Kinnunen 2008; Maddison 2014; Martin 1997; Patten 2017; Prapavessis 2016; Russell 1988; Taylor 1988; Whiteley 2012; Ussher 2003; Ussher 2015), six included some element of reinforcement (Bernard 2015; Martin 1997; Patten 2017; Prapavessis 2016; Ussher 2003; Ussher 2015), Hill 1993 used telephone follow-up in the case of non-attendance, Prapavessis 2016 offered a telephone maintenance programme, and Taylor 1988 used remote monitoring of heart rate. To assist self-monitoring, two studies provided pedometers (Maddison 2014; Ussher 2015) and one supplied Kinetic Activity Monitors (Prapavessis 2016). Six trials used comprehensive exercise counselling, including a broad range of behaviour change techniques (Bernard 2015; Maddison 2014; Patten 2017; Prapavessis 2016; Ussher 2003; Ussher 2015).

Where supervised exercise was offered, attendance at these sessions was high, except in two studies where fewer than $50 \%$ of sessions were attended (Smits 2016; Ussher 2015). Where the emphasis was on independent/home-based exercise (Bize 2010; Maddison 2014; Marcus 2005; McKay 2008; Ussher 2003), only a minority of the participants achieved the target level of exercise, except where an exercise app was promoted, in which case exercise levels were significantly higher for the exercise group compared with controls at six-month follow-up, despite low uptake of the app (Hassan- 
dra 2017). In Patten 2017, only two of 15 participants attended the YMCA post-intervention to use a free six-month membership. One study reported greater attrition for the exercise group compared with the controls (Marcus 1999 - see Borrelli 2002). Three studies reported lower attendance for the exercise intervention compared with the control intervention (Kinnunen 2008; Smits 2016; Whiteley 2012).

Besides reporting on attendance at supervised exercise sessions, most studies assessed changes in self-reported physical activity levels (Abrantes 2014; Bernard 2015; Bize 2010; Ciccolo 2011; Hassandra 2017; Hill 1985; Kinnunen 2008; Maddison 2014; McKay 2008; Patten 2017; Prapavessis 2016; Ussher 2003; Ussher 2015; Whiteley 2012). Of the 11 studies comparing activity levels for exercise versus control groups (Abrantes 2014; Bernard 2015; Bize 2010; Hassandra 2017; Maddison 2014; McKay 2008; Patten 2017; Prapavessis 2016; Ussher 2003; Ussher 2015; Whiteley 2012), seven reported significantly higher activity levels for exercise versus control participants at one follow-up at least (Abrantes 2014; Bize 2010; Hassandra 2017; Maddison 2014; Ussher 2003; Ussher 2015; Whiteley 2012). Only two studies objectively assessed changes in physical activity (Bernard 2015; Ussher 2015), both using accelerometers, and one of the studies only tested a sub-sample of participants (Ussher 2015); neither study showed a significant difference in changes in objectively-assessed activity levels between the study groups.

\section{Smoking cessation programmes/Comparator}

Twenty-two studies included smoking cessation support as the comparator, and two studies had relapse prevention support as the comparator (Hassandra 2017; Prapavessis 2016), with 23 studies offering this support for both exercise and control groups; one study provided this support only for the control group (McKay 2008). Twenty-one of the studies provided a multisession cognitive behavioural smoking cessation or relapse prevention programme for both intervention and control groups, with one study delivering the programme by telephone (Abrantes 2014), another by face-toface and telephone contact (Maddison 2014), and the rest were all face-to-face. Among the remaining three studies, one provided a single cessation session for all participants (Taylor 1988); in another study the exercise group received cessation counselling on alternate weeks whereas the control group only received one brief session of cessation counselling (Bernard 2015), which confounds the effects of exercise; the third study delivered a smoking cessation programme through the Internet, only for the nonexercise condition (McKay 2008). Twelve studies provided pharmacotherapy for smoking cessation or relapse prevention, which in all cases was matched between intervention and control: eight studies included nicotine patches (Abrantes 2014; Ciccolo 2011; Marcus 2005; Patten 2017; Prapavessis 2007; Prapavessis 2016; Smits 2016; Ussher 2003); one study provided nicotine gum (Kinnunen 2008); two offered several types of nicotine replacement therapy (Bize 2010; Maddison 2014); and one offered patches, gum or varenicline (Bernard 2015).
Twenty of the 22 studies recruiting current smokers set a quit date, and one set a quit date for the non-exercise condition but did not specify whether or not the exercise group set a quit date (McKay 2008). In fifteen studies the cessation programme began prior to the quit day (Abrantes 2014; Bernard 2015; Hassandra 2017; Hill 1993; Kinnunen 2008; Maddison 2014; Marcus 1999; Marcus 2005; Patten 2017; Prapavessis 2007; Prapavessis 2016; Smits 2016; Ussher 2003; Ussher 2015; Whiteley 2012).

In summary, 22 studies compared exercise plus smoking cessation support to this support alone, and provided an unconfounded estimate of the effect of exercise on smoking cessation. Neither of the two relapse prevention studies provided an unconfounded estimate of exercise plus smoking relapse prevention support compared with this support alone.

\section{Outcomes for smoking abstinence}

The strictest measure of abstinence was continuous in 11 studies, prolonged abstinence in three, point prevalence in eight, and was not specified in two. Smoking abstinence was validated objectively in all but three studies (Hassandra 2017; Maddison 2014; McKay 2008). In six studies the method of validation was both measurement of carbon monoxide (CO) in expired air and saliva cotinine (Kinnunen 2008; Marcus 1999; Marcus 2005; Prapavessis 2007; Smits 2016; Ussher 2015), 10 studies used expired CO alone (Abrantes 2014; Bernard 2015; Bize 2010; Ciccolo 2011; Hill 1985; Hill 1993; Martin 1997; Prapavessis 2016; Russell 1988; Ussher 2003), four studies used cotinine alone (Marcus 1991; Marcus 1995; Patten 2017; Whiteley 2012) and one used plasma thiocyanate (Taylor 1988).

\section{Excluded studies}

We list 108 studies that were potentially relevant but excluded, with detailed reasons, in the Characteristics of excluded studies table. We summarise reasons for excluding studies at full-text stage in Figure 1 . The reason for excluding most studies at full-text screening stage was because the study had an ineligible design, and in most cases this was because the study was examining the acute effects of exercise rather than examining effects on smoking cessation outcomes. We have added 56 new excluded studies since the previous version of the review. We also classify seven studies as ongoing (see Characteristics of ongoing studies table), which are likely to be relevant for inclusion once reported.

\section{Risk of bias in included studies}

Full details of 'Risk of bias' assessments are given for each trial within the Characteristics of included studies table. Overall, we judged two studies to be at low risk of bias (low risk of bias across all domains), 11 at high risk of bias (high risk of bias in at least one domain), and the remaining 11 at unclear risk of bias. A summary illustration of the 'Risk of bias' profile across trials is shown in Figure 2. 
Figure 2. Risk of bias summary: review authors' judgements about each risk of bias item for each included study.

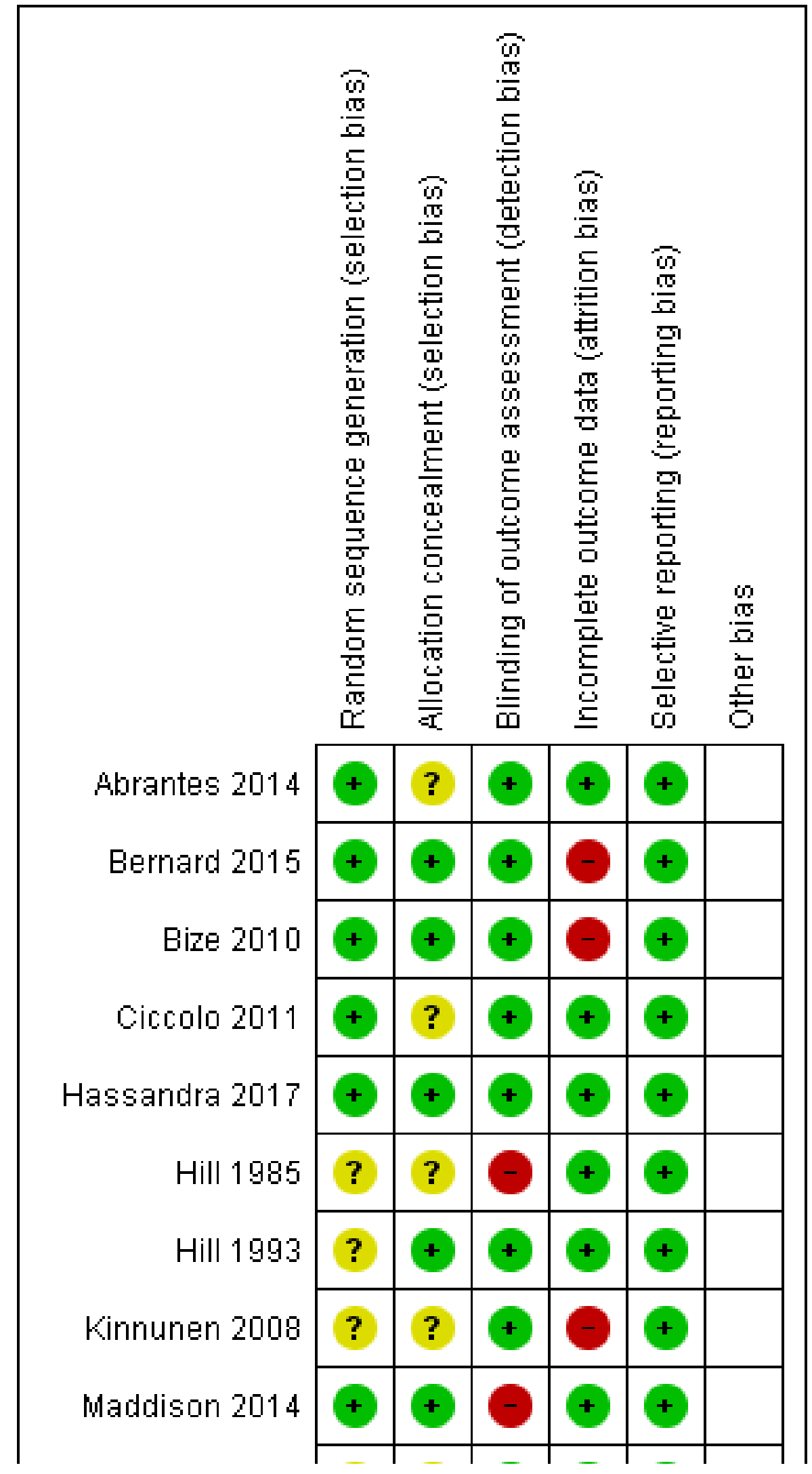


Figure 2. (Continued)

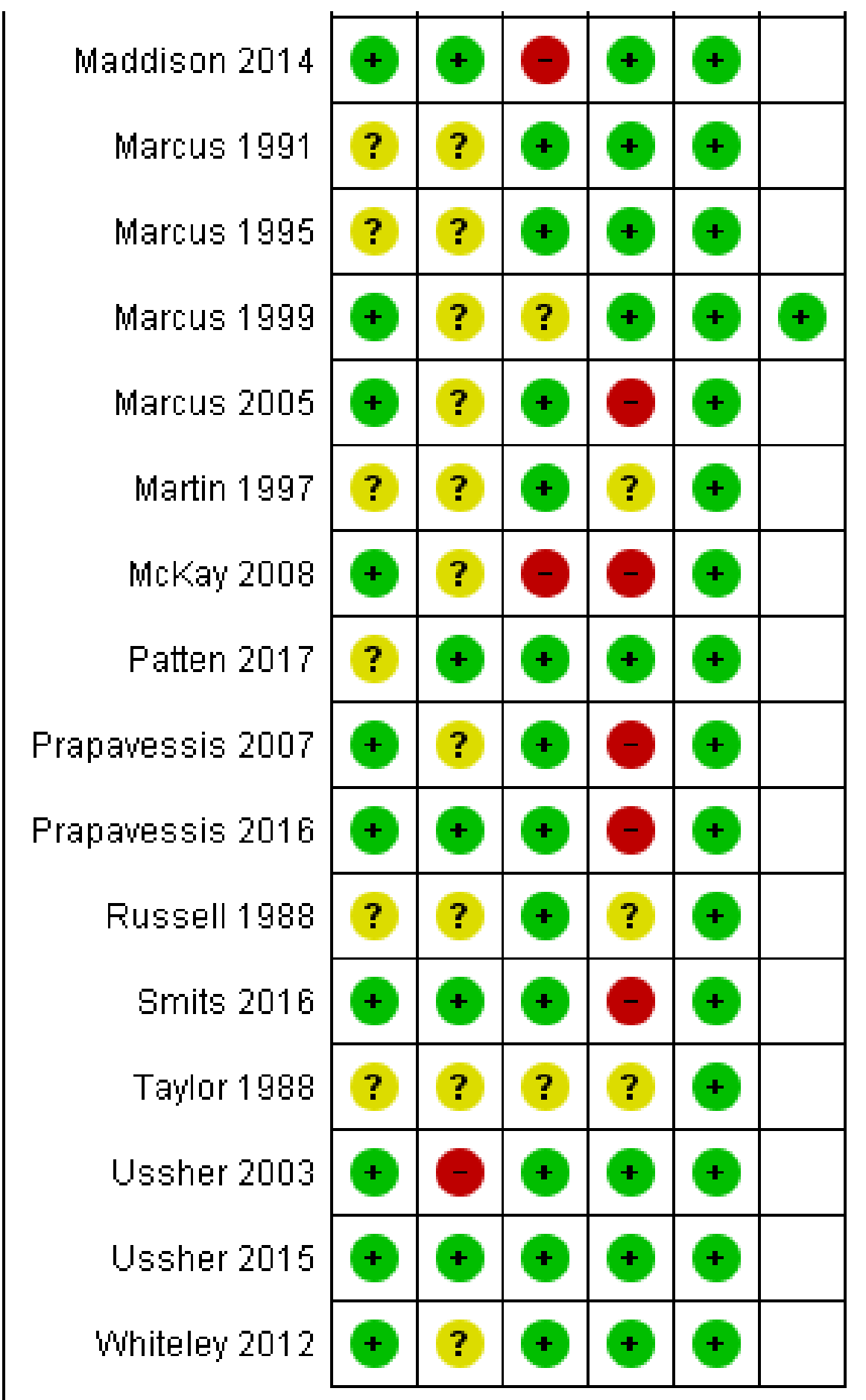




\section{Allocation}

We assessed selection bias through investigating methods of random sequence generation and allocation concealment for each study. We rated 15 studies as having low risk for random sequence generation, and the remaining nine as having unclear risk. We judged nine studies to be at low risk for allocation concealment, 14 at unclear risk, and one study at high risk (Ussher 2003). We rated Ussher 2003 at high risk as study personnel used a list of random numbers, and therefore knew which condition a person was in before they were randomised. We judged studies as having unclear risk of selection bias when authors provided insufficient information about methods used.

\section{Outcome assessment (detection bias)}

We rated 19 studies at low risk for detection bias, as smoking cessation was biochemically validated. We judged two studies to be at unclear risk of detection bias, as we were unsure whether abstinence rates were biochemically verified. We judged three studies to be at high risk of detection bias (Hill 1985; Maddison 2014; McKay 2008), as these studies relied on self-report alone.

\section{Incomplete outcome data}

We judged studies to be at a low risk of attrition bias where the numbers of participants lost to follow-up were clearly reported, the overall number lost to follow-up was not more than $50 \%$, and the difference in loss to follow-up between groups was no greater than $20 \%$. This is consistent with 'Risk of bias' guidance produced by the Cochrane Tobacco Addiction Group for assessing smoking cessation studies. We judged 13 studies to be at low risk of bias, three at unclear risk and eight at high risk. We judged these eight studies to be at high risk because overall loss to follow-up was more than 50\% (Bernard 2015; Bize 2010; Kinnunen 2008; Marcus 2005; McKay 2008; Prapavessis 2016; Smits 2016), or because the groups had a difference in loss to follow-up of more than 20\% (Prapavessis 2007). We assigned judgements of unclear risk because information on follow-up was not reported (Martin 1997; Russell 1988; Taylor 1988).

\section{Selective reporting}

We rated all the studies at a low risk of reporting bias, as all studies reported the outcomes for smoking cessation as stated in their Methods.

\section{Other potential sources of bias}

We did not identify any other sources of bias.

\section{Effects of interventions}

See: Summary of findings for the main comparison Exercise interventions for smoking cessation

\section{Smoking abstinence}

See: Summary of findings for the main comparison; Analysis 1.1; and Analysis 1.2.

We included 23 of the 24 studies in analyses; we dropped one study as it did not provide separate abstinence data for the experimental and control groups, although it was reported that no significant difference was found between the groups (Russell 1988).
For the first analysis (see Analysis 1.1), we pooled 21 studies comparing exercise versus no exercise intervention, on smoking cessation outcomes (i.e. aimed at current smokers wishing to quit smoking). This resulted in a pooled risk ratio (RR) of $1.08(95 \% \mathrm{Cl} 0.96$ to 1.22; 6607 participants), with no statistical heterogeneity $(12=0 \%)$. This provides no evidence for an effect of the exercise intervention on smoking cessation. We then analysed the trials in subgroups, stratified by type of exercise. The exercise types/subgroups were: cardiovascular-type exercise (17 studies, 3635 participants), resistance training (1 study, 25 participants), cardiovascular-type exercise and resistance training combined (1 study, 330 participants), or exercise type not specified (2 studies, 2617 participants). There was no evidence of subgroup differences $(P=0.72,12=0 \%)$.

We then conducted a sensitivity analysis to see if the overall results were sensitive to exclusion of the six studies with special populations; i.e. those with mental health issues (Bernard 2015; Martin 1997; Patten 2017), with other specific psychological symptoms (Smits 2016), with a pregnant population (Ussher 2015), and with a physical health condition (Taylor 1988). Excluding these studies did not affect the interpretation of the results (RR 1.06, 95\% Cl 0.92 to $1.22 ; 12=0 \%$; 5376 participants). We conducted a further sensitivity analysis removing the 10 studies judged to be at high risk of bias (see Figure 2); the pooled estimate was higher than in the main analysis (RR $1.25,95 \% \mathrm{Cl} 0.99$ to $1.58 ; \mathrm{I}^{2}=0 \% ; 1802$ participants), but the interpretation remained the same. A post hoc sensitivity analysis removing the two studies where smoking cessation support was not matched between the intervention and control arms (Bernard 2015; McKay 2008) also did not affect the results (RR 1.09, 95\% Cl 0.95 to $1.25 ; 1^{2}=0 \% ; 4219$ participants).

Next we conducted an analysis pooling the two relapse prevention studies (i.e. aimed at smokers who had recently quit) (Hassandra 2017; Prapavessis 2016). This resulted in a pooled RR of 0.98 (95\% $\mathrm{Cl} 0.65$ to $1.47 ; \mathrm{I}^{2}=0 \%$; 453 participants), providing no evidence for exercise interventions aiding relapse prevention (see Analysis 1.2). We judged one of these studies (Prapavessis 2016) as having high risk of bias.

\section{Potential mechanisms of action}

As none of the included studies detected a statistically significant benefit in favour of the intervention we did not assess mechanisms of action as they related to individual study findings. We summarise below the findings related to the all the different mechanisms examined in the studies.

\section{Smoking reduction}

Six of the included studies assessed changes in levels of cigarette consumption as a secondary outcome (Bernard 2015; Hill 1985; Taylor 1988; Prapavessis 2007; Maddison 2014; Ussher 2015). None of these studies reported a significant smoking reduction for the exercise versus the control group. Two studies observed significantly lower absolute levels of smoking for an exercise group versus control at 23 week post-treatment (Taylor 1988) and 24 weeks after quit day (Maddison 2014), although they did not analyse the changes in smoking relative to baseline. One trial reported significantly lower smoking levels for a cessation programme versus an exercise programme (Prapavessis 2007). 
Cigarette cravings, withdrawal symptoms and other psychological measures

Nine studies assessed effects on cigarette withdrawal symptoms or cravings or both, and there was little evidence for the exercise interventions having a beneficial effect. Abrantes 2014 reported significantly lower somatic withdrawal symptoms and sleep disturbance for the exercise versus control group during the treatment period; there were no group differences for craving. Ussher 2003 observed a reduction in some withdrawal symptoms for exercise versus controls up to three weeks post-cessation. Other studies assessing withdrawal symptoms or cravings or both observed no overall effect of the intervention on these outcomes (Bernard 2015; Bize 2010; Hassandra 2017; Kinnunen 2008; Maddison 2014; Marcus 1999; Ussher 2015), although Marcus 1999 observed a beneficial acute reduction in withdrawal and cravings for the exercise versus control group (see Bock 1999).

Nine studies examined symptoms of depression, mood or anxiety. When assessing mood/depression, five studies observed no significant effect of the intervention (Abrantes 2014; Bernard 2015; Bize 2010; Martin 1997; Patten 2017); two of these focused on those with symptoms of moderate to severe depression (Bernard 2015; Patten 2017) and a further study recruited those recovering from alcohol dependence (Martin 1997). Marcus 2005 observed that those who increased their fitness were more likely to report decreases in depressive symptoms (see Williams 2008). Among pregnant smokers, Ussher 2015 observed a significant increase in self-reports of depression symptoms for the exercise group compared with the control group at the end of pregnancy (see Daley 2018). Based on qualitative work (Giatras 2017), the authors concluded that having to cope with changing two health behaviours simultaneously (i.e. smoking and exercise), while also coping with being pregnant and attending multiple treatment sessions, may have negatively affected participants' mood. Bernard 2015 found no effect of the intervention on reports of anxiety, but Russell 1988 detected a significant increase in tension-anxiety scores for the active group compared with the controls. Among those with high levels of anxiety sensitivity, Smits 2016 showed that the intervention reduced anxiety sensitivity.

\section{Fitness measures}

Thirteen studies examined changes in fitness levels (Abrantes 2014; Bernard 2015; Ciccolo 2011; Kinnunen 2008; Marcus 1991; Marcus 1995; Marcus 1999; Marcus 2005; Patten 2017; Prapavessis 2007; Russell 1988; Taylor 1988; Whiteley 2012 (sub-sample only)) and five of these showed significant gains in cardiovascular fitness for an exercise versus control group at end of treatment (Bernard 2015; Patten 2017; Prapavessis 2007; Taylor 1988; Whiteley 2012). A further four studies reported significant gains in cardiovascular fitness at end of treatment within an exercise group but not within a control group, although they did not compare the groups statistically (Marcus 1991; Marcus 1995; Marcus 1999 (see also Albrecht 1998); Marcus 2005).

\section{Weight or body mass index}

Twelve studies examined weight changes, and one study assessed BMI. Marcus 1999 reported a significantly smaller weight gain for those in the exercise condition compared with the controls at the end of treatment; however, those in the exercise condition weighed more than the controls at baseline, and this difference was not controlled for, which makes interpretation of the finding problematic.
This study did not find any significant differences in weight change between the study groups at the three-month or 12-month follow-ups. Prapavessis 2007 observed no difference in weight gain at end of treatment when comparing cognitive-behavioural support plus nicotine patches with exercise plus nicotine patches; however, at end of treatment those in the exercise-only condition gained significantly less weight than those receiving only cognitive-behavioural support. Other studies found no difference in weight gain for the exercise versus controls at end of treatment (Bernard 2015; Marcus 1991; Marcus 1995; Marcus 2005; Ussher 2003; Whiteley 2012), at three- and six-month follow-ups (Ciccolo 2011), at 12 months post-cessation (Bize 2010; Ussher 2003) or at end of pregnancy (Ussher 2015). Patten 2017 observed no group difference for $\mathrm{BMI}$ at end of treatment.

\section{DISCUSSION}

\section{Summary of main results}

This update contributed six new studies evaluating exercise programmes for smoking cessation. The review includes 24 trials in total. Twenty-one of these trials compared a combined exercise and smoking cessation intervention with smoking cessation support alone, one compared exercise alone to smoking cessation support (McKay 2008), and two compared a combined exercise and relapse prevention intervention with relapse prevention alone (Hassandra 2017; Prapavessis 2016). One study could not be included in meta-analysis (Russell 1988).

A meta-analysis, pooling all 21 available studies comparing exercise to smoking cessation treatment indicated no evidence of a benefit for the exercise intervention on smoking cessation. We judged this estimate to be of low certainty, as it was imprecise and there was suspected publication bias (see Quality of the evidence; Summary of findings for the main comparison). There was no evidence of different effects by the type of exercise, and the estimate remained the same when we removed six studies with special populations, and when we removed two studies in which smoking cessation support was not matched between the intervention and control arms. When we removed 10 studies at high risk of bias, the point estimate changed to be more in favour of exercise, but the interpretation was unchanged.

Pooling the two relapse prevention studies provided no evidence for the exercise interventions aiding relapse prevention. Due to one of these studies being rated at high risk of bias and to a lack of precision around the $\mathrm{Cl}$, we judged the estimate as being of very low certainty.

\section{Overall completeness and applicability of evidence}

There were marked variations between the studies in the length, type, and timing of the exercise intervention, and in the design of the control condition and cessation programme. Despite this variation, the observed effects were very consistent, with no evidence of any statistical heterogeneity. Although pooled analyses did not show evidence of an effect, there are a number of limitations to the evidence base which could potentially have impacted effectiveness and which need to be considered when planning further research in this area.

The studies were mainly conducted in the USA, with others taking place in other high-income countries; studies are needed in low-and middle-income countries where population smoking rates 
are higher. Most of the studies were conducted among the general population of smokers, with only six studies among various special populations. These special populations might find it harder to stop smoking and to increase exercise levels, so we conducted a sensitivity analysis excluding the six studies. Reassuringly, results were not sensitive to the exclusion of these studies. Trials are needed among other special populations of smokers who might especially benefit from an exercise intervention. There is a high prevalence of smoking among those with serious mental illness, and those with such disorders are likely to be receptive to exercise as an aid to cessation (Arbour-Nicitopoulos 2011; Arbour-Nicitopoulos 2011b; Faulkner 2007); trials are therefore needed in this population. Studies are also needed to examine the effect of exercise interventions on smoking cessation in younger smokers; an excluded study showed that young smokers may benefit from exercise (Horn 2011). People with overweight or obesity who quit smoking may have a particular need for weight control interventions, such as exercise (Lycett 2011), and we have yet to see a trial of exercise focusing on this population, although there was little evidence in this review to suggest that exercise interventions are likely to have an impact on weight change during smoking cessation. However, among the included studies not observing any effect on weight, several were too small to have a realistic chance of detecting a treatment effect (Bernard 2015; Ciccolo 2011; Marcus 1991; Marcus 1995; Patten 2017; Whiteley 2012). Moreover, the studies by Bernard 2015, Bize 2010, Marcus 2005, Patten 2017, Ussher 2003, and Whiteley 2012 included NRT, and post-cessation weight gain is likely to be less pronounced when using NRT (Farley 2012). The potential for exercise to moderate weight gain was therefore reduced. It is possible that exercise provides a role in weight management once an individual has stopped using NRT, but this has yet to be explored. Only two of the studies recruited reasonably active smokers (Hassandra 2017; Ussher 2015). A substantial proportion of smokers may be physically active (Deruiter 2008; Emmons 1994; Scioli 2009; Ward 2003) and there is some evidence that regular exercisers may be more successful at quitting (Abrantes 2009; Derby 1994; Paavola 2001), but it is not clear whether exercise interventions are effective as an aid to smoking cessation in more active populations.

It has been recommended that a smoking cessation programme should start before the quit date and continue into the period of abstinence (Raw 1998). However, almost half of the trials did not do this (Ciccolo 2011; Hill 1985; Maddison 2014; Marcus 1991; Marcus 1995; Martin 1997; McKay 2008; Russell 1988; Taylor 1988) and one study, testing an app, only provided a single session of support after the quit day (Hassandra 2017).

There is some evidence that exercise is effective for reducing cigarette cravings even when a nicotine lozenge is used (Tritter 2015). Further studies are needed to establish whether exercise offers additional benefits to those provided by NRT and other smoking cessation medications. It is feasible that exercise could address psychosocial and physical needs that are not currently met by NRTbased programmes. Alternatively, exercise may have limited impact on cigarette cravings if cravings have been reduced by NRT; it is worth noting that most acute exercise studies have shown significantly reduced cravings following experimentally elevated cravings (Haasova 2013).

For those studies beginning exercise either on or after the quit date (Ciccolo 2011; Hassandra 2017; Hill 1985; Maddison 2014; Martin 1997; Russell 1988; Taylor 1988) success rates may have been hampered by the demand to cope simultaneously with two major changes in health behaviour (Emmons 1994; Hyman 2007; King 1996; Patten 2003). In studies where the exercise programme started after a period of smoking abstinence, the potential for exercise to moderate withdrawal symptoms during this period was lost (Haasova 2013; Roberts 2012). A review of the comparative efficacy of simultaneous versus sequential multiple health behaviour change interventions concluded that the approaches should be considered equally efficacious (James 2016). In practice, when the exercise programme begins may depend on individual capabilities and preferences (Everson-Hock 2010b).

More attention may need to be given to strategies for increasing exercise adherence. In the two studies with exercise programmes lasting for less than six weeks (Hill 1985; Martin 1997), the intervention may have been of insufficient length to encourage longterm exercise adherence. Where a home/unsupervised exercise programme was not provided it is possible that the participants' high level of dependence on supervised exercise reduced their level of post-intervention activity. Most of the studies involved cardiovascular-type exercise and more studies are needed with noncardiovascular exercise. For example, isometric exercise has been shown to reduce tobacco cravings and urges to smoke (Ussher 2006; Ussher 2009), and has been successfully piloted (Al-Chalabi 2008).

Only five studies promoted exercise as a coping strategy for managing cigarette cravings (Bernard 2015; Hassandra 2017; Patten 2017; Ussher 2003; Ussher 2015). The effect of the interventions may have been stronger if exercise were actively presented as such a coping strategy (Taylor 2010). The evidence consistently demonstrates the benefits of an acute bout of exercise on alleviating cravings and withdrawal symptoms under optimum conditions for observing such an effect (i.e. with experimentally manipulated increased baseline cravings - through temporary abstinence, and in some cases in the presence of smoking-related cues, prior to exercising). As regards relapse prevention, exercise could be presented as a strategy which increases self-esteem and pride in one's health, and reinforces an identity as a non-smoker and as a physically active person (Verkooijen 2008; Taylor 2014) in such a way that being a smoker is incompatible with these perceptions. Critically, if exercise aids smoking cessation, it is likely that exercise needs to be maintained for it to continue to support smoking cessation.

Among the included studies, only two offered digital support towards pursuing independent/home-based exercise (Hassandra 2017; McKay 2008), providing Internet and app-based support respectively. Further studies need to consider offering these types of support, as well as other common digital support such as text/ SMS messaging. Patten 2018 has recently shown that smokers are receptive to robotic-assisted exercise coaching, and other novel digital interventions need to be explored for supporting independent exercise among smokers who are trying to quit. Only two studies objectively assessed changes in physical activity (Bernard 2015; Ussher 2015); future studies need to assess exercise dosage through including both self-reported and objective measures of physical activity, as well as recording supervised exercise attendance.

Those adequately-powered trials not showing a consistent effect of exercise on smoking abstinence (Bize 2010; Maddison 2014; Marcus 2005; McKay 2008; Prapavessis 2016; Ussher 2003; Ussher 2015) promoted moderate- or moderate to vigorous-intensity exercise, 
rather than vigorous-intensity exercise. One of these studies relied solely on brief exercise counselling (Ussher 2003), and another focused on telephone-based counselling (Maddison 2014). In two other studies supervised exercise was only provided once a week (Bize 2010; Marcus 2005), and another study relied on a web-based programme (McKay 2008). In these studies the exercise intervention may have been insufficiently intense to benefit smoking abstinence. Future studies should consider providing more intensive interventions. Intensity here refers to both the exercise intensity itself (i.e. light, moderate or vigorous) and the extensiveness of the support being provided (e.g. the number of supervised exercise sessions). The findings from Marcus 2005 suggest that abstaining smokers may need to accumulate at least 110 minutes of activity a week to maintain abstinence (at least during the intervention period), and supervised exercise on two or three days a week may be necessary to achieve this. A pilot study showed promising findings for an intervention involving moderate-intensity exercise supervised on three days a week over eight weeks (Williams 2010); this needs to be tested in a larger trial.

Only five of the studies provided any post-intervention exercise programming (Hassandra 2017; Hill 1993; Maddison 2014; Prapavessis 2016; Ussher 2003), and this may have increased postintervention exercise adherence. Hassandra 2017 made an exercise-promoting app available for use through to six-month follow-up, and observed that self-reported physical activity levels were higher for the exercise versus control group at six months. Prapavessis 2016 offered telephone counselling up to 12 months posttreatment and found no difference in activity levels for the study groups between baseline and six or 12 months after treatment. For the other studies providing post-intervention exercise programming it is not possible to draw any conclusions about whether the intervention affected levels of exercise adherence after the formal supervised programme ended, because none of these studies reported rates of adherence for this period.

\section{Quality of the evidence}

As described above and in Summary of findings for the main comparison, we rated the evidence in this review to be of low certainty for smoking cessation. Although 21 studies contributed to the meta-analysis of smoking cessation, many of them were small, and imprecision remained an issue, with confidence intervals spanning both no effect and a clinically significant benefit. A funnel plot (Figure 3) was asymmetrical, suggesting the presence of publication bias, with small studies appearing more likely to be published if they detected a greater effect. This sort of asymmetry risks inflating the estimated effect. In addition, we judged 10 of the 21 studies contributing to the main analysis to be at high risk of bias. However, when we removed these studies findings were consistent with the overall analysis, although the point estimate more clearly favoured the intervention. 
Figure 3. Funnel plot of comparison: 1 Exercise component versus smoking cessation programme only, outcome: 1.1 Smoking abstinence at longest follow-up, subgroup by exercise type.

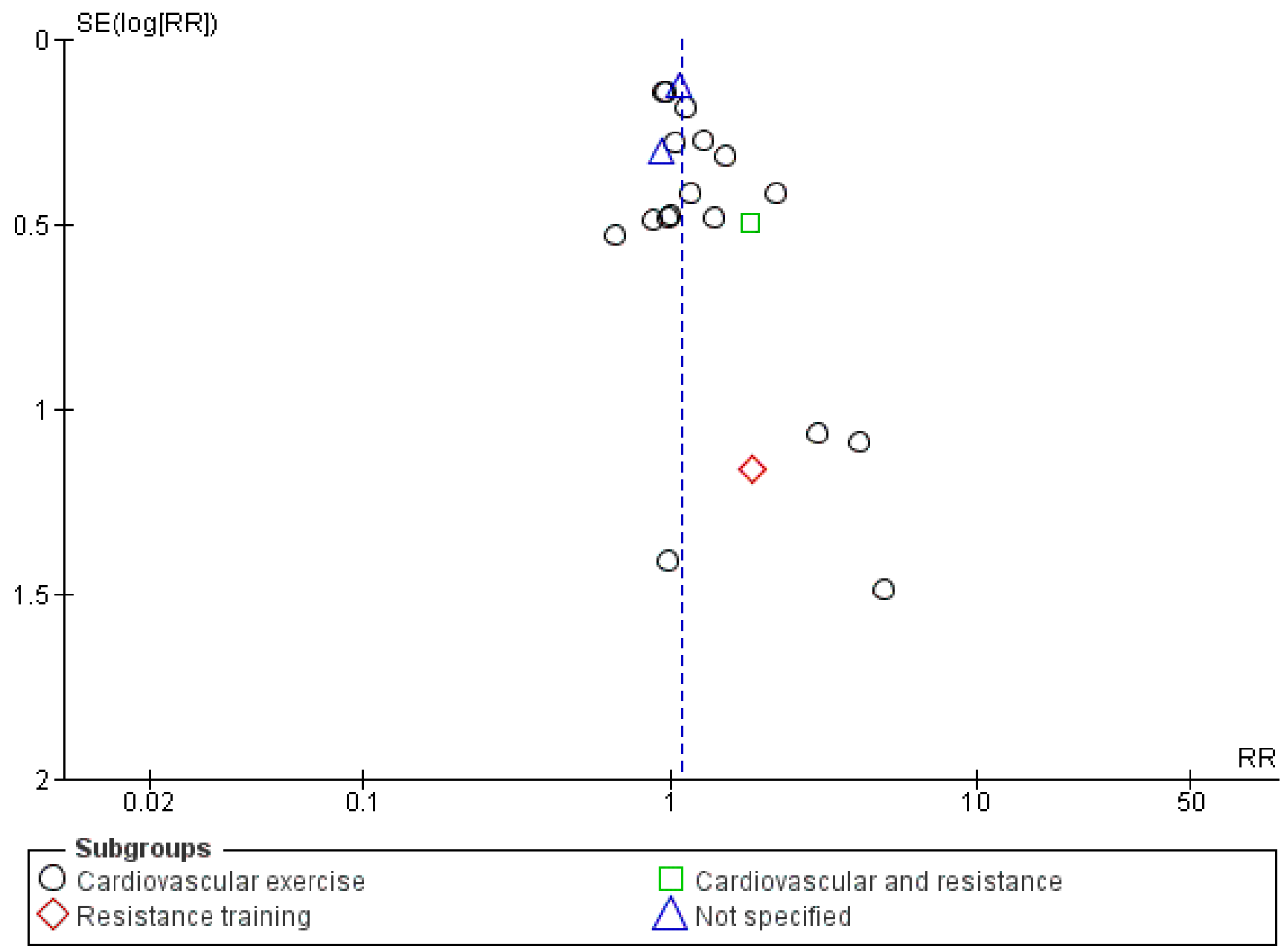

Only two studies contributed to the analysis of relapse prevention; here quality was very low, due to serious imprecision (confidence intervals spanning both a clinically significant benefit and clinically significant harm) and to risk of bias (we judged the larger of the two studies contributing to the analysis to be at high risk of bias).

Overall, our judgement is that the true effect of exercise interventions for smoking cessation may be substantially different from the effect estimate observed when pooling the available data.

\section{Potential biases in the review process}

We followed standard Cochrane methods and are unaware of any introduced bias. Three review authors were authors of included studies, but these studies were assessed independently by other members of the author team, again following standard Cochrane methods. Our search strategy included the Cochrane Tobacco Addiction Group Specialised Register and we also searched trial registries and contacted key authors in an attempt to capture unpublished and ongoing studies. There may be unpublished data that our searches did not reveal, and our funnel plot indicates that this may bias results for the comparison for smoking cessation.

\section{Agreements and disagreements with other studies or reviews}

The findings are consistent with previous versions of this review and with a previous meta-analysis of exercise interventions for smoking cessation (Klinsophon 2017). The findings are not consistent with a multitude of 'laboratory' studies showing that brief bouts of exercise can acutely reduce withdrawal and cravings (Haasova 2013; Haasova 2014; Roberts 2012), which presents probably the most plausible explanation of how an exercise intervention might aid smoking cessation or relapse prevention. This inconsistency may be because the acute studies involved temporarily abstinent smokers rather than those attempting to stop smoking completely. Moreover, as this evidence comes from single bouts of acute exercise it is possible that for the laboratory results to be replicated during quit attempts individuals will need to take part in multiple bouts of exercise throughout the day. It is also plausible that the effect of exercise does not last very long and it is not feasible for people to exercise with sufficient frequency through the day. The intervention effect is therefore short-lived and not that effective. We observed little evidence for exercise having an impact on weight, but, when pooling the results from three studies in this review (Bize 2010; Marcus 1999; Ussher 2003), Farley 2012 found 
no evidence for exercise moderating weight gain at end of treatment, but reported a benefit at 12-month follow-up, concluding that "More studies are needed to clarify whether this is an effect of treatment or a chance finding". Additionally, Spring 2009 conducted a meta-analysis with 10 studies of weight management interventions during smoking cessation, including five of the studies included in our review (Marcus 1991; Marcus 1995; Marcus 1999; Marcus 2005; Ussher 2003), and observed a significant benefit for the intervention in the short term (less than three months), but not in the long term (more than six months).

\section{A U THORS' CONCLUSIONS}

\section{Implications for practice}

There is insufficient evidence to support exercise as a specific aid to smoking cessation.

\section{Implications for research}

Further trials are needed with larger sample sizes, sufficiently intense exercise interventions, techniques for maximising exercise adherence, and objective measures of exercise levels. Studies are needed in low- and middle-income countries, and among special populations of smokers who might especially benefit from an exercise intervention, such as those with serious mental illness, younger smokers, and people with overweight or obesity.

\section{ACKNOWLEDGEMENTS}

We would like to acknowledge Robert West and Andrew McEwen, who contributed to earlier versions of this review. We would also like to thank Professor Harry Prapavessis and an anonymous researcher for conducting peer review, and Lee Bromhead for providing consumer review.

This project was supported by the National Institute for Health Research (NIHR), via Cochrane Infrastructure and Cochrane Programme Grant funding to the Cochrane Tobacco Addiction Group. The views and opinions expressed therein are those of the authors and do not necessarily reflect those of the Systematic Reviews Programme, NIHR, NHS, or the Department of Health and Social Care. JHB is also part-funded by the NIHR Oxford Biomedical Research Centre (BRC). 


\section{R E F E R E N C E S}

\section{References to studies included in this review}

\section{Abrantes 2014 \{published data only\}}

* Abrantes AM, Bloom EL, Strong DR, Riebe D, Marcus BH, Desaulniers $\mathrm{J}$, et al. A preliminary randomized controlled trial of a behavioral exercise intervention for smoking cessation. Nicotine \& Tobacco Research 2014;16(8):1094-13.

Abrantes AM, Zywiak W, Strong DR, Riebe D, Desaulniers J, Brown RA. Smoking status as a moderator of the acute effects of aerobic exercise among smokers in cessation treatment (POS1-155). Society for Research on Nicotine \& Tobacco 19th Annual Meeting, March 13-16, Boston, MA. 2013. [CRS: 9400129000001202]

\section{Bernard 2015 \{published data only\}}

Bernard P, Ninot G, Cyprien F, Courtet P, Guillaume S, Georgescu V, et al. Exercise and counseling for smoking cessation in smokers with depressive symptoms: a randomized controlled pilot trial. Journal of Dual Diagnosis 2015;11(3-4):205-16

\section{Bize 2010 \{published data only\}}

* Bize R, Willi C, Chiolero A, Stoianov R, Payot S, Locatelli I, et al. Participation in a population-based physical activity programme as an aid for smoking cessation: a randomised trial. Tobacco Control 2010;19(6):488-94.

Cornuz J, Willi C, Chiolero A, Payot S, Stoianov R, Bize R. Physical activity as an aid to smoking cessation: A randomized controlled trial of sedentary adults smokers. Journal of General Internal Medicine 2007;22(S1):107.

Locatelli I, Clair C, Collet T-H, Rodondi N, Cornuz J. The interaction between gender and amount of smoking in the prediction of one-year weight gain after smoking cessation. Journal of General Internal Medicine 2012;27(2 Suppl):S333-4. [CRS: 9400130000000344; EMBASE: 71296995]

Prod'hom S, Locatelli I, Giraudon K, Marques-Vidal P, Clair C, Bize $R$, et al. Predictors of weight change in sedentary smokers receiving a standard smoking cessation intervention. Nicotine \& Tobacco Research 2013;15(5):910-6. [PUBMED: 23048177]

\section{Ciccolo 2011 \{published data only\}}

Ciccolo JT, Dunsiger SI, Williams DM, Bartholomew JB, Jennings $\mathrm{EG}$, Ussher $\mathrm{MH}$, et al. Resistance training as an aid to standard smoking cessation treatment: a pilot study. Nicotine \& Tobacco Research 2011;13(8):756-60.

\section{Hassandra 2017 \{published data only\}}

* Hassandra M, Lintunen T, Hagger MS, Heikkinen R, Vanhala M, Kettunen T. An mHealth app for supporting quitters to manage cigarette cravings with short bouts of physical activity: a randomized pilot feasibility and acceptability study. JMIR Mhealth Uhealth 2017;26:e74.

Hassandra M, Lintunen T, Kettunen T, Vanhala M, Toivonen HM, Kinnunen K, et al. Effectiveness of a mobile phone app for adults that uses physical activity as a tool to manage cigarette craving after smoking cessation: a study protocol for a randomized controlled trial. JMIR Research Protocols 2015;4(4):e125.

Hill 1985 \{published data only\}

Hill JS. Effect of a program of aerobic exercise on the smoking behaviour of a group of adult volunteers. Canadian Journal of Public Health 1985;76(3):183-6.

Hill 1993 \{published data only\}

Hill RD, Rigdon M, Johnson S. Behavioural smoking cessation treatment for older chronic smokers. Behavioural Therapy 1993;24:321-9.

\section{Kinnunen 2008 \{published data only\}}

* Kinnunen T, Leeman RF, Korhonen T, Quiles ZN, Terwal DM, Garvey AJ, et al. Exercise as an adjunct to nicotine gum in treating tobacco dependence among women. Nicotine \& Tobacco Research 2008;10(4):689-703.

Korhonen T, Kinnunen T, Quiles Z, Leeman RF, Terwal DM, Garvey AJ. Cardiovascular risk behavior among sedentary female smokers and smoking cessation outcomes. Tobacco Induced Disease 2005;3(1):7-26.

Mustonen T. Aerobic exercise as a behavioral adjunct to nicotine replacement therapy among female smokers. Society for Research on Nicotine and Tobacco 11th Annual Meeting. Prague, Czech Republic. 20-23 March. 2005.

Quiles ZN, Leeman RF, Molinelli L, Nordstrom BL, Garvey AJ, Hartley LH, et al. Exercise as a behavioral adjunct to nicotine gum for smoking cessation - preliminary findings (PO2 42). Society for Research on Nicotine and Tobacco 8th Annual Meeting February 20-23, 2002, Savannah, Georgia. 2002:59.

\section{Maddison 2014 \{published data only\}}

Jiang Y, Maddison R, McRobbie H, Bullen C, Roberts V, Glover M, et al. Can exercise enhance smoking cessation outcomes? A pragmatic randomized controlled trial (fit2quit Study). Clinical Trials (London, England) 2012;9(4):484-5. [CENTRAL: 834599; CRS: 9400123000015597 ; EMBASE: 70866143]

Maddison R, Roberts V, Bullen C, McRobbie H, Jiang Y, Prapavessis $\mathrm{H}$, et al. Design and conduct of a pragmatic randomized controlled trial to enhance smoking-cessation outcomes with exercise: The Fit2Quit study. Mental Health and Physical Activity 2010;3:92-101.

* Maddison R, Roberts V, McRobbie H, Bullen C, Prapavessis H, Glover M, et al. Exercise counseling to enhance smoking cessation outcomes: the Fit2Quit randomized controlled trial. Annals of Behavioral Medicine 2014;48(2):194-204. [CRS: 9400129000001081; PUBMED: 24604528]

\section{Marcus 1991 \{published data only\}}

Marcus BH, Albrecht AE, Niaura RS, Abrams DB, Thompson PD. Usefulness of physical exercise for maintaining smoking cessation in women. American Journal of Cardiology 1991;68(4):406-7. 
Marcus 1995 \{published data only\}

Marcus BH, Albrecht AE, Niaura RS, Taylor ER, Simkin LR, Feder SI, et al. Exercise enhances the maintenance of smoking cessation in women. Addictive Behaviors 1995;20(1):87-92.

\section{Marcus 1999 \{published data only\}}

Albrecht AE, Marcus BH, Roberts M, Forman DE, Parisi AF. Effect of smoking cessation on exercise performance in female smokers participating in exercise training. American Journal of Cardiology 1998;82(8):950-5.

Bock BC, Marcus BH, King TK, Borrelli B, Roberts MR. Exercise effects on withdrawal and mood among women attempting smoking cessation. Addictive Behaviors 1999;24(3):399-410.

Borrelli B, Hogan JW, Bock B, Pinto B, Roberts M, Marcus B. Predictors of quitting and dropout among women in a clinicbased smoking cessation program. Psychology of Addictive Behaviors 2002;16(1):22-7.

* Marcus BH, Albrecht AE, King TK, Parisi AF, Pinto BM, Roberts $\mathrm{M}$, et al. The efficacy of exercise as an aid for smoking cessation in women: a randomised controlled trial. Archives of Internal Medicine 1999;159(11):1229-34.

Marcus BH, King TK, Albrecht AE, Parisi AF, Abrams DB. Rationale, design, and baseline data for Commit to Quit: An exercise efficacy trial for smoking cessation among women. Preventive Medicine 1997;26(4):586-97.

\section{Marcus 2005 \{published data only\}}

Albrecht AE, Parisi AF, Roberts M, Marcus BH. Exercise and smoking quit rates in women: moderate versus vigorous exercise. Medicine and Science in Sports and Exercise 2004;36(5 Suppl):S231.

Marcus B, Lewis B, Hogan J, King T, Albrecht RN, Bock B, et al. The efficacy of moderate intensity physical activity for smoking cessation among women. Annual Meeting of the Society of Behavioral Medicine, Salt Lake City, USA. 2003.

* Marcus BH, Lewis BA, Hogan J, King TK, Albrecht AE, Bock B, et al. The efficacy of moderate-intensity exercise as an aid for smoking cessation in women: a randomized controlled trial. Nicotine \& Tobacco Research 2005;7(6):871-80.

Marcus BH, Lewis BA, King TK, Albrecht AE, Hogan J, Bock B, et al. Rationale, design, and baseline data for Commit to Quit II: an evaluation of the efficacy of moderate-intensity physical activity as an aid to smoking cessation in women. Preventive Medicine 2003;36(4):479-92.

\section{Martin 1997 \{published data only\}}

* Martin JE, Calfas KJ, Patten CA. Prospective evaluation of three smoking interventions in 205 recovering alcoholics: oneyear results of project SCRAP-Tobacco. Journal of Consulting and Clinical Psychology 1997;65(1):190-4.

Patten CA, Martin JE, Calfas KJ, Brown SA, Schroeder DR. Effect of three smoking cessation treatments on nicotine withdrawal in 141 abstinent alcoholic smokers. Addictive Behaviors 2000;25(2):301-6.
Patten CA, Martin JE, Calfas KJ, Lento J, Wolter TD. Behavioral treatment for smokers with a history of alcoholism: predictors of successful outcome. Journal of Consulting and Clinical Psychology 2001;69(5):796-801.

Patten CA, Vickers KS, Martin JE, Williams CD. Exercise interventions for smokers with a history of alcoholism: Exercise adherence rates and effect of depression on adherence. Addictive Behaviors 2003;28(4):657-67.

McKay 2008 \{published data only\}

McKay HG, Danaher BG, Seeley JR, Lichtenstein E, Gau JM. Comparing two web-based smoking cessation programs: randomized controlled trial. Journal of Medical Internet Research 2008;10(5):e40.

Patten 2017 \{published data only\}

Patten CA, Bronars CA, Vickers Douglas KS, Ussher MH, Levine JA, Tye SJ, et al. Supervised, vigorous intensity exercise intervention for depressed female smokers: a pilot study. Nicotine \& Tobacco Research 2017;19(1):77-86.

\section{Prapavessis 2007 \{published data only\}}

Hammett CJ, Prapavessis H, Baldi JC, Varo N, Schoenbeck U, Ameratunga $\mathrm{R}$, et al. Effects of exercise training on 5 inflammatory markers associated with cardiovascular risk. American Heart Journal 2006;151(2):367.e7-367.e17.

Prapavessis $\mathrm{H}$. The effects of exercise and nicotine replacement therapy on smoking rates in women. Eighth International Congress of Behavioural Medicine, Mainz, Germany. 2004.

* Prapavessis H, Cameron L, Baldi JC, Robinson S, Borrie K, Harper T, et al. The effects of exercise and nicotine replacement therapy on smoking rates in women. Addictive Behaviors 2007;32(7):1416-32. [PUBMED: 17097814]

\section{Prapavessis 2016 \{published data only\}}

Jung ME, Fitzgeorge L, Prapavessis H, Faulkner G, Maddison R. The Getting Physical on Cigarettes trial: Rationale and methods. Mental Health and Physical Activity 2010;3:35-44.

* Prapavessis H, De Jesus S, Fitzgeorge L, Faulkner G, Maddison R, Batten S. Exercise to enhance smoking cessation: the Getting Physical on Cigarettes randomized control trial. Annals of Behavioral Medicine 2016;50(3):358-69.

\section{Russell 1988 \{published data only\}}

Russell PO, Epstein LH, Johnson JJ, Block DR, Blair E. The effects of physical activity as maintenance for smoking cessation. Addictive Behaviors 1988;13(2):215-8.

Smits 2016 \{published data only\}

* Smits JA, Zvolensky MJ, Davis ML, Rosenfield D, Marcus BH, Church TS, et al. The efficacy of vigorous-intensity exercise as an aid to smoking cessation in adults with high anxiety sensitivity: a randomized controlled trial. Psychosomatic Medicine 2016;78(3):354-64

Smits JAJ, Zvolensky MJ, Rosenfield D, Marcus BH, Church TS, Frierson GM, et al. The efficacy of vigorous-intensity exercise as an aid to smoking cessation in adults with elevated anxiety 
sensitivity: study protocol for a randomized controlled trial. Trials 2012;13:207. [PUBMED: 23148822]

Zvolensky MJ, Rosenfield D, Garey L, Kauffman BY, Langdon KJ, Powers MB, et al. Does exercise aid smoking cessation through reductions in anxiety sensitivity and dysphoria?. Health Psychology 2018;37(7):647-57.

\section{Taylor 1988 \{published data only\}}

Taylor CB, Houston-Miller N, Haskell WL, Debusk RF. Smoking cessation after acute myocardial infarction: The effects of exercise training. Addictive Behaviors 1988;13(4):331-4.

\section{Ussher 2003 \{published data only\}}

* Ussher M, West R, McEwen A, Taylor A, Steptoe A. Efficacy of exercise counselling as an aid for smoking cessation: a randomized controlled trial. Addiction 2003;98(4):523-32.

Ussher M, West R, McEwen A, Taylor A, Steptoe A. Efficacy of exercise counselling as an aid to smoking cessation: $A$ randomised controlled trial. European Conference of the Society for Research on Nicotine and Tobacco. 2001.

Ussher M, West R, McEwen A, Taylor AH, Steptoe A. Randomized controlled trial of physical activity counseling as an aid to smoking cessation: 12 month follow-up. Addictive Behaviors 2007;32(12):3060-4

\section{Ussher 2015 \{published data only\}}

Daley A, Riaz M, Lewis S, Aveyard P, Coleman T, Manyonda I, et al. Physical activity for antenatal and postnatal depression in women attempting to quit smoking: randomised controlled trial. BMC Pregnancy and Childbirth 2018;18(1):156.

Giatras N, Wanninkhof E, Leontowitsch M, Lewis B, Taylor A, Cooper $\mathrm{S}$, et al. Lessons learned from the London Exercise and Pregnant (LEAP) Smokers randomised controlled trial process evaluation: implications for the design of physical activity for smoking cessation interventions during pregnancy. BMC Public Health 2017;17(1):85.

Ussher M, Aveyard P, Manyonda I, Lewis S, West R, Lewis B, et al. Physical activity as an aid to smoking cessation during pregnancy: the LEAP randomised trial protocol. Trials 2012;13:186. [CENTRAL: 863871; CRS: 9400107000000019 ; PUBMED: 23035669]

Ussher M, Lewis S, Aveyard P, Manyonda I, West R, Lewis B, et al. The London Exercise And Pregnant smokers (LEAP) trial: a randomised controlled trial of physical activity for smoking cessation in pregnancy with an economic evaluation. Health Technology Assessment 2015;19(84):vii-xxiv; 1-135.

* Ussher M, Lewis S. Aveyard P, Manyonda I, West R, Lewis B, et al. A randomised trial of physical activity as an aid to smoking cessation during pregnancy. BMJ 2015;350:2145.

\section{Whiteley 2012 \{published data only\}}

* Whiteley JA, Williams DM, Dunsiger S, Jennings EG, Ciccolo JT, Bock BC, et al. YMCA commit to quit: randomized trial outcomes. American Journal of Preventive Medicine 2012;43(3):256-62. [CENTRAL: 834611; CRS: 9400123000015737 ; EMBASE: 2012516881; PUBMED: 22898118]
Whiteley JA, Williams DM, Jennings EG, Ciccolo JT, Bock BC, Dunsiger $\mathrm{S}$, et al. The challenges of translating an efficacious smoking cessation program, Commit to Quit, to the community setting of YMCAs. Translational Behavioral Medicine 2013;3(1):47-58.

\section{References to studies excluded from this review}

\section{Abrantes 2017 \{published data only\}}

Abrantes AM, Farris SG, Garnaat SL, Minto A, Brown RA, Price LH, et al. The role of physical activity enjoyment on the acute mood experience of exercise among smokers with elevated depressive symptoms. Mental Health and Physical Activity 2017;12:37-43.

\section{Abrantes 2018 \{published data only\}}

Abrantes AM, Farris SG, Minami H, Strong DR, Riebe D, Brown RA. Acute effects of aerobic exercise on affect and smoking craving in the weeks before and after a cessation attempt. Nicotine \& Tobacco Research 2018;20(5):575-82.

\section{Aggarwal 2017 \{published data only\}}

Aggarwal A, Kumar K. Yoga as a powerful tool for smoking cessation-convincing results of a community based randomised controlled trial. Journal of Thoracic Oncology 2017;12(1 Supplement):S1486-S1487.

\section{Al-Chalabi 2008 \{published data only\}}

Al-Chalabi L, Prasad N, Steed L, Stenner S, Aveyard P, Beach J, et al. A pilot randomised controlled trial of the feasibility of using body scan and isometric exercises for reducing urge to smoke in a smoking cessation clinic. BMC Public Health 2008;8:349.

\section{Al-Eisa 2016 \{published data only\}}

Al-Eisa E, Alghadir AH, Gabr SA, Iqbal ZA. Exercise intervention as a protective modulator against metabolic disorders in cigarette smokers. Journal of Physical Therapy Science 2016;28(3):983-91.

\section{Allen 2018a \{published data only\}}

Allen A, Carlson SC, Bosch TA, Eberly LE, Okuyemi K, Nair U, et al. High-intensity interval training and continuous aerobic exercise interventions to promote self-initiated quit attempts in young adults who smoke: feasibility, acceptability, and lessons learned from a randomized pilot trial. Journal of Addiction Medicine 2018;12(5):373-80.

\section{Allen 2018b \{published data only\}}

Allen AM, Abdelwahab NM, Carlson S, Bosch TA, Eberly LE, Okuyemi K. Effect of brief exercise on urges to smoke in men and women smokers. Addictive Behaviors 2018;77:34-7.

\section{Angeli 2018 \{published data only\}}

Angeli M, Hatzigeorgiadis A, Comoutos N, Krommidas C, Morres ID, Theodorakis $Y$. The effects of self-regulation strategies following moderate intensity exercise on ad libitum smoking. Addictive Behaviors 2018;87:109-14.

\section{Arbour-Nicitopoulos 2011 \{published data only\}}

Arbour-Nicitopoulos KP, Faulkner GE, Hsin A, Selby P. A pilot study examining the acute effects of exercise on craving 
reduction and affect among individuals with serious mental illness. Mental Health \& Physical Activity 2011;4(2):89-94.

Audrain-McGovern 2015 \{published data only\}

Audrain-McGovern J, Strasser AA, Ashare R, Wileyto EP. Reinforcing value of smoking relative to physical activity and the effects of physical activity on smoking abstinence symptoms among young adults. Experimental and Clinical Psychopharmacology 2015;23(6):477-85.

\section{Bernard 2013 \{published data only\}}

Bernard PP, Esseul EC, Raymond L, Dandonneau L, Xambo JJ, Carayol MS, et al. Counseling and exercise intervention for smoking reduction in patients with schizophrenia: a feasibility study. Archives of Psychiatric Nursing 2013;27(1):23-31.

Blank 2017 \{published data only\}

Blank MD, Ferris KA, Metzger A, Gentzler A, Duncan C, Jarrett T, et al. Physical activity and quit motivation moderators of adolescent smoking reduction. American Journal of Health Behavior 2017;41(4):419-27.

\section{Bock 2012 \{published data only\}}

Bock BC, Fava JL, Gaskins R, Morrow KM, Williams DM, Jennings $\mathrm{E}$, et al. Yoga as a complementary treatment for smoking cessation in women. Journal of Women's Health 2012;21(2):240-8. [CENTRAL: 814361; CRS: 9400123000012676 ; EMBASE: 2012076111; PUBMED: 21992583]

\section{Caliani 2004 \{published data only\}}

Espinosa Caliani S, Brava Navas JC, Gómez-Doblas JJ, Rivera RC, González Jiménez BG, Martínez Lao M, et al. Postmyocardial infarction cardiac rehabilitation in low risk patients. Results with a coordinated program of cardiological and primary care. Revista Espanola de Cardiologia 2004;57(1):53-9.

\section{Chaney 2008 \{published data only\}}

Chaney SE, Sheriff S. Weight gain among women during smoking cessation: testing the effects of a multifaceted program. American Association of Occupational Health Nurses Journal 2008;56(3):99-105.

\section{Cinciripini 1996 \{published data only\}}

Cinciripini PM, Cinciripini LG, Wallfisch A, Haque W, Van Vunakis H. Behavior therapy and the transdermal nicotine patch: effects on cessation outcome, affect, and coping. Journal of Consulting and Clinical Psychology 1996;64(2):314-23.

Clark 2005 \{published data only\}

Clark MM, Hays JT, Vickers KS, Patten CA, Croghan IT, Berg E, et al. Body image treatment for weight concerned smokers: A pilot study. Addictive Behaviors 2005;30(6):1236-40.

\section{Conklin 2017 \{published data only\}}

Conklin CA, Soreca I, Kupfer DJ, Cheng Y, Salkeld RP, Mumma JM, et al. Exercise attenuates negative effects of abstinence during 72 hours of smoking deprivation. Experimental and Clinical Psychopharmacology 2017;25(4):265-72

\section{Cooke 2016 \{published data only\}}

Cooke LM, Fitzgeorge L, Hall CR, Prapavessis H. Imagine that: Examining the influence of exercise imagery on cigarette cravings and withdrawal symptoms. Journal of Smoking Cessation 2016;11:28-36. [DOI: 10.1017/jsc.2014.13.]

Copeland 2006 \{published data only\}

Copeland AL, Martin PD, Geiselman PJ, Rash CJ, Kendzor DE. Smoking cessation for weight-concerned women: group vs. individually tailored, dietary, and weight-control follow-up sessions. Addictive Behaviors 2006;31(1):115-27.

Daley 2004 \{published data only\}

Daley AJ, Oldham AR, Townson M. The effects of acute exercise on affective responses and desire to smoke in sedentary temporarily abstaining smokers: a preliminary study. Journal of Sports Sciences 2004;22:303-4.

Daniel 2004 \{published data only\}

Daniel JZ, Cropley M, Ussher M, West R. Acute effects of a short bout of moderate versus light intensity exercise versus inactivity on tobacco withdrawal symptoms in sedentary smokers. Psychopharmacology (Berl) 2004;174(3):320-6.

Daniel 2006 \{published data only\}

Daniel JZ, Cropley M, Fife-Schaw C. The effect of exercise in reducing desire to smoke and cigarette withdrawal symptoms is not caused by distraction. Addiction 2006;101(8):1187-92.

Daniel 2007 \{published data only\}

Daniel JZ, Cropley M, Fife-Schaw C. Acute exercise effects on smoking withdrawal symptoms and desire to smoke are not related to expectation. Psychopharmacology 2007;195:125-9.

De Jesus 2014 \{published data only\}

De Jesus S, Murray E, Prapavessis H. No evidence for harm reduction: acute exercise modifies ad libitum smoking and affect but not smoking behaviour. Society for Research on Nicotine and Tobacco Annual Conference, Seattle, USA. 2014

De Jesus 2018a \{published data only\}

De Jesus S, Prapavessis H. Affect and cortisol mechanisms through which acute exercise attenuates cigarette cravings during a temporary quit attempt. Addictive Behaviors 2018;80:82-8.

\section{De Jesus 2018b \{published data only\}}

De Jesus S, Prapavessis H. Smoking behaviour and sensations during the pre-quit period of an exercise-aided smoking cessation intervention. Addictive Behaviors 2018;81:143-9.

\section{Elibero 2011 \{published data only\}}

Elibero A, Janse van Rensburg K, Drobes DJ. Acute effects of aerobic exercise and hatha yoga on craving to smoke. Nicotine \& Tobacco Research 2011;13(11):1140-8.

\section{Everson 2006 \{published data only\}}

Everson ES, Daley AJ, Ussher M. Does exercise have an acute effect on desire to smoke, mood and withdrawal symptoms in abstaining adolescent smokers. Addictive Behaviors 2006;31(9):1547-58. 
Everson 2008 \{published data only\}

Everson ES, Daley AJ, Ussher M. The effects of moderate and vigorous exercise on desire to smoke, withdrawal symptoms and mood in abstaining young adult smokers. Mental Health and Physical Activity 2008;1:26-31.

Faulkner 2010 \{published data only\}

Faulkner G, Arbour-Nicitopoulos K, Hsin A. Cutting down one puff at a time: The acute effects of exercise on smoking behaviour. Journal of Smoking Behavior 2010;5:130-5.

\section{Fong 2014 \{published data only\}}

Fong AJ, De Jesus S, Bray SR, Prapavessis H. Effect of exercise on cigarette cravings and ad libitum smoking following concurrent stressors. Addictive Behaviors 2014;39(10):1516-21.

\section{Fortmann 1995 \{published data only\}}

Fortmann SP, Killen JD. Nicotine gum and self-help behavioral treatment for smoking relapse prevention: results from a trial using population-based recruitment. Journal of Consulting and Clinical Psychology 1995;63(3):460-8.

\section{Garcia 2019 \{published data only\}}

Salgado Garcia FI, Derefinko KJ, Bursac Z, Klesges RC, Ebbert JO, Womack CR, et al. Fit \& quit: An efficacy trial of two behavioral post-cessation weight gain interventions. Contemporary Clinical Trials 2019;76:31-40.

\section{Gorini 2012 \{published data only\}}

Chellini E, Gorini G, Carreras G, Giordano L, Anghinoni E, lossa A, et al. The Pap smear screening as an occasion for smoking cessation and physical activity counselling: baseline characteristics of women involved in the SPRINT randomized controlled trial. BMC Public Health 2011;11:906.

* Gorini G, Carreras G, Giordano L, Anghinoni E, lossa A, Coppo A, et al. The Pap smear screening as an occasion for smoking cessation and physical activity counselling: effectiveness of the SPRINT randomized controlled trial. BMC Public Health 2012;12:740.

\section{Grove 1993 \{published data only\}}

Grove JR, Wilkinson A, Dawson BT. Effects of exercise on selected correlates of smoking withdrawal. International Journal of Sport Psychology 1993;24:217-36.

\section{Grove 2006 \{published data only\}}

Grove JR, Wilkinson A, Dawson BT, Eastwood PR, Heard NP. Effects of exercise on subjective aspects of sleep during tobacco withdrawal. Australian Psychologist 2005;41: 69-76.

\section{Haasova 2011 \{published data only\}}

Haasova M, Oh H, Taylor AT. The acute effects of brisk walking and isometric exercise versus rest on cigarette cravings and attentional bias. Paper presented at ASH Wales; 2011 Oct; Cardiff, UK.

\section{Harper 2012 \{published data only\}}

Harper T, Fitzgeorge L, Tritter A, Prapavessis H. Acute exercise effects on craving and withdrawal symptoms among women attempting to quit smoking using nicotine replacement therapy. Journal of Smoking Cessation 2012;7(2):72-9. [CRS: 9400107000001480]

\section{Harper 2013 \{published data only\}}

Harper T, Fitzgeorge L, Tritter A, Prapavessis H. Are treatment expectations related to reductions in craving and withdrawal symptoms following an acute bout of exercise?. Mental Health and Physical Activity 2013;6(2):83-6. [CRS: 9400126000000286 ]

Hassandra 2012 \{published data only\}

Hassandra M, Kofou G, Zourbanos N, Gratsani S, Zisi V, Theodorakis Y. Initial evaluation of a smoking cessation program incorporating physical activity promotion to Greek adults in antismoking clinics. Evaluation \& the Health Professions 2012;35(3):323-30.

\section{Hatzigeorgiadis 2016 \{published data only\}}

Hatzigeorgiadis A, Pappa V, Tsiami A, Tzatzaki T, Georgakouli K, Zourbanos N, et al. Self-regulation strategies may enhance the acute effect of exercise on smoking delay. Addictive Behaviors 2016;57:35-7.

\section{Ho 2014 \{published data only\}}

Ho JY, Kraemer WJ, Volek JS, Vingren JL, Fragala MS, Flanagan SD, et al. Effects of resistance exercise on the HPA axis response to psychological stress during short-term smoking abstinence in men. Addictive Behaviors 2014;39(3):695-8.

\section{Horn 2011 \{published data only\}}

Horn K, Branstetter S, Zhang J, Jarrett T, Tompkins NO, Anesetti-Rothermel A, et al. Understanding physical activity outcomes as a function of teen smoking cessation. Journal of Adolescent Health 2013;53(1):125-31. [CENTRAL: 905650; CRS: 9400107000000780; EMBASE: 2013390794; PUBMED: 23578440]

* Horn K, Dino G, Branstetter S, Zhang J, Noerachmanto N, Jarrett T, et al. The effects of physical activity on teen smoking cessation. Pediatrics 2011;128(4):e801-11.

\section{Hurt 1994 \{published data only\}}

Hurt RD, Eberman KM, Croghan IT, Offord KP, Davis LJ Jr, Morse RM, et al. Nicotine dependence treatment during inpatient treatment for other addictions: a prospective intervention trial. Alcoholism, Clinical and Experimental Research 1994;18(4):867-72.

\section{Hwang 2012 \{published data only\}}

Hwang GS, Jung HS, Yi Y, Yoon C, Choi JW. Smoking cessation intervention using stepwise exercise incentives for male workers in the workplace. Asia-Pacific Journal of Public Health / Asia-Pacific Academic Consortium for Public Health 2012;24(1):82-90. [CRS: 9400123000013005; PUBMED: 21159694]

Janse van Rensburg 2008 \{published data only\} Janse van Rensburg K, Taylor AH. The effects of acute exercise on cognitive functioning and cigarette cravings during temporary abstinence from smoking. Human Psychopharmacology: Clinical and Experimental 2008;23(3):193-9. 


\section{Janse van Rensburg 2009a \{published data only\}}

Van Rensburg KJ, Taylor AH, Hodgson T. The effects of acute exercise on attentional bias towards smoking-related stimuli during temporary abstinence from smoking. Addiction 2009;104(11):1910-17.

\section{Janse van Rensburg 2009b \{published data only\}}

Van Rensburg KJ, Taylor A, Hodgson T, Benattayallah A. Acute exercise modulates cigarette cravings and brain activation in response to smoking-related images: an fMRI study. Psychopharmacology 2009;203(3):589-98.

\section{Janse van Rensburg 2010 \{unpublished data only\}} Janse van Rensburg K. The effects of exercise on neuropsychological processes associated with a desire to smoke nicotine and cue-elicited cravings [PhD dissertation]. University of Exeter, UK, 2010.

\section{Janse van Rensburg 2012 \{published data only\}}

Janse van Rensburg K, Taylor A, Benattayallah A, Hodgson T. The effects of exercise on cigarette cravings and brain activation in response to smoking-related images. Psychopharmacology 2012;221(4):659-66. [CRS: 9400123000015844; EMBASE: 2012357180; PUBMED: 22234380]

\section{Janse van Rensburg 2013 \{published data only\}}

Janse van Rensburg K, Elibero A, Kilpatrick M, Drobes DJ. Impact of aerobic exercise intensity on craving and reactivity to smoking cues. Experimental and Clinical Psychopharmacology 2013;21(3):196-203. [CENTRAL: 963513; CRS: 9400130000000234; PUBMED: 23750690]

\section{Jones 2001 \{published data only\}}

Jones C, Griffiths RD, Skirrow P, Humphris G. Smoking cessation through comprehensive critical care. Intensive Care Medicine 2001;27(9):1547-9.

\section{Jonsdottir 2001 \{published data only\}}

Jonsdottir $\mathrm{D}$, Jonsdottir $\mathrm{H}$. Does physical exercise in addition to a multicomponent smoking cessation program increase abstinence rate and suppress weight gain? An intervention study. Scandinavian Journal of the Caring Sciences 2001;15(4):275-82.

\section{Katomeri 2007 \{published data only\}}

Katomeri M. Acute effects of self-paced walking on smoking withdrawal and cravings [PhD dissertation]. University of Plymouth, 2007.

\section{Kinnunen 2013 \{published data only\}}

* Kinnunen T, Craft LL, Korhonen T. Exercise as an adjunct to standard treatment for sedentary female smokers: short- and long-term cessation outcomes (POS4-168). Society for Research on Nicotine \& Tobacco 19th Annual Meeting, March 13-16, Boston, MA. 2013.

Korhonen T, Goodwin A, Miesmaa P, Dupuis EA, Kinnunen T. Smoking cessation program with exercise improves cardiovascular disease biomarkers in sedentary women. Journal of Womens Health (Larchmt) 2011;20(7):1051-64.
Kovelis 2012 \{published data only\}

Kovelis D, Zabatiero J, Furlanetto KC, Mantoani LC, Proença M, Pitta F. Short-term effects of using pedometers to increase daily physical activity in smokers. Respiratory Care 2012;57(7):1089-97.

\section{Kurti 2014a \{published data only\}}

Kurti AN, Dallery J. Effects of exercise on craving and cigarette smoking in the human laboratory. Addictive Behaviors 2014;39(6):1131-7.

\section{Kurti 2014b \{published data only\}}

Kurti AN, Dallery J. A laboratory-based evaluation of exercise plus contingency management for reducing cigarette smoking. Drug and Alcohol Dependence 2014;144:201-209.

\section{Leelarungrayub 2010 \{published data only\}}

Leelarungrayub D, Pratanaphon S, Pothongsunun P, Sriboonreung T, Yankai A, Bloomer RJ. Vernonia cinerea Less. supplementation and strenuous exercise reduce smoking rate: relation to oxidative stress status and beta-endorphin release in active smokers. Journal of the International Society of Sports Nutrition 2010;7:21.

\section{Linke 2012 \{published data only\}}

Linke SE, Rutledge T, Myers MG. Intermittent exercise in response to cigarette cravings in the context of an Internetbased smoking cessation program. Mental Health and Physical Activity 2012;5(1):85-92. [CRS: 9400123000014625 ; EMBASE: 2012311344]

\section{Loprinzi 2015 \{published data only\}}

Loprinzi PD, Wolfe CD, Walker JF. Exercise facilitates smoking cessation indirectly via improvements in smoking-specific selfefficacy: prospective cohort study among a national sample of young smokers. Preventive Medicine 2015;81:63-66.

\section{Luo 2019 \{published data only\}}

Luo J, Manson JE, Hendryx M, Shadyab AH, Johnson KC, Dinh PC Jr, et al. Physical activity and weight gain after smoking cessation in postmenopausal women. Menopause 2019;26(1):16-23.

\section{Mantoani 2014 \{published data only\}}

Mantoani LC, Furlanetto KC, Kovelis D, Proença M, Zabatiero J, Bisca $G$, et al. Long-term effects of a program to increase physical activity in smokers. Chest 2014;146(6):1627-32.

\section{McClure 2009 \{published data only\}}

McClure JB, Ludman EJ, Grothaus L, Pabiniak C, Richards J. Impact of a brief motivational smoking cessation intervention. The get PHIT randomized controlled trial. American Journal of Preventive Medicine 2009;37(2):116-23.

McClure 2011 \{published data only\}

McClure JB, Catz SL, Ludman EJ, Richards J, Riggs K, Grothaus L. Feasibility and acceptability of a multiple risk factor intervention: the Step Up randomized pilot trial. BMC Public Health 2011;11:167. 


\section{Mclver 2004 \{published data only\}}

Mclver S, O'Halloran P, McGartland M. The impact of Hatha yoga on smoking behavior. Alternative Therapy Health \& Medicine 2004;10(2):22-3.

\section{Mikhail 1983 \{published data only\}}

Mikhail C. The acute effects of aerobic exercise on cigarette smoking [Masters Thesis]. University of Lethbridge, Canada., 1983.

\section{Nair 2017 \{published data only\}}

Nair US, Patterson F, Rodriguez D, Collins BN. A telephonebased intervention to promote physical activity during smoking cessation: a randomized controlled proof-of-concept study. Translational Behavioral Medicine 2017;7(2):138-47.

\section{Nguyen 2012 \{published data only\}}

Nguyen QN, Pham ST, Nguyen VL, Weinehall L, Wall S, Bonita R, et al. Effectiveness of community-based comprehensive healthy lifestyle promotion on cardiovascular disease risk factors in a rural Vietnamese population: a quasi-experimental study. BMC Cardiovascular Disorders 2012;12:56.

\section{Oenema 2008 \{published data only\}}

Oenema A, Brug J, Dijkstra A, De Weerdt I, de Vries H. Efficacy and use of an internet-delivered computer-tailored lifestyle intervention, targeting saturated fat intake, physical activity and smoking cessation: a randomized controlled trial. Annals of Behavioral Medicine 2008;35(2):125-35.

\section{Oh 2014 \{published data only\}}

$\mathrm{Oh} \mathrm{H}$, Taylor AH. Self-regulating smoking and snacking through physical activity. Health Psychology 2014;33(4):349-59. [CRS: 9400107000000683; PUBMED: 23668849]

\section{Ortega Sanchez-Pinilla 2006 \{published data only\}}

Ortega Sánchez-Pinilla R, Aquilar-Blanco EM. Running and its influence on smoking habits. Atencion Primaria 2006;37(9):478-81.

\section{Pomerleau 1987 \{published data only\}}

Pomerleau OF, Scherzer HH, Grunberg NE, Pomerleau CS, Judge J, Fetig JB, et al. The effects of acute exercise on subsequent cigarette smoking. Journal of Behavioral Medicine 1987;10(2):117-27.

\section{Prapavessis 2014 \{published data only\}}

Prapavessis H, De Jesus S, Harper T, Cramp A, Fitzgeorge L, Mottola MF, et al. The effects of acute exercise on tobacco cravings and withdrawal symptoms in temporary abstinent pregnant smokers. Addictive Behaviors 2014;39(3):703-8. [CRS: 9400130000000505; EMBASE: 2014014988]

Priebe 2017 \{published data only\} Priebe CS, Atkinson J, Faulkner G. Run to Quit: an evaluation of a scalable physical activity-based smoking cessation intervention. Mental Health and Physical Activity 2017;13:15-21.

\section{Prochaska 2008 \{published data only\}}

Prochaska JJ, Hall SM, Humfleet G, Munoz RF, Reus V, Goerecki J, et al. Physical activity as a strategy for maintaining tobacco abstinence: a randomized controlled trial. Preventive Medicine 2008;47(2):215-20.

\section{Ramsay 2004 \{published data only\}}

Ramsay J, Hoffmann A. Smoking cessation and relapse prevention among undergraduate students: a pilot demonstration project. Journal of the American College of Health. 2004;53(1):11-8.

\section{Reeser 1983 \{published data only\}}

Reeser KA. The effects of repeated aerobic and non-aerobic exercise on cigarette smoking [Masters Thesis]. University of Alberta, Canada, 1983.

\section{Reid 2014 \{published data only\}}

Reid RD, McDonnell LA, Riley DL, Mark AE, Mosca L, Beaton L, et al. Effect of an intervention to improve the cardiovascular health of family members of patients with coronary artery disease: a randomized trial. Canadian Medical Association Journal 2014;186(1):23-30.

\section{Roberts 2015 \{published data only\}}

Roberts V, Gant N, Sollers JJ 3rd, Bullen C, Jiang Y, Maddison R. Effects of exercise on the desire to smoke and physiological responses to temporary smoking abstinence: a crossover trial. Psychopharmacology 2015;232(6):1071-81.

\section{Saltychev 2012 \{published data only\}}

Saltychev M, Laimi K, El-Metwally A, Oksanen T, Pentti J, Virtanen $M$, et al. Effectiveness of multidisciplinary early rehabilitation in reducing behaviour-related risk factors. Journal of Rehabilitation Medicine 2012;44(4):370-7.

\section{Scerbo 2010 \{published data only\}}

* Scerbo F, Faulkner G, Taylor A, Thomas S. Effects of exercise on cravings to smoke: the role of exercise intensity and cortisol. Journal of Sports Sciences 2010;28(1):11-9.

Scerbo, F. The impact of acute vigorous physical activity on cravings, affect, and cortisol concentration among abstinent smokers experiencing withdrawal [Master's thesis]. University of Toronto, Canada, 2007.

\section{Schneider 2015 \{published data only\}}

Schneider T, De Jesus S, Prapavessis H. The effect of acute exercise on smoking topography: No evidence for cutting down one puff at a time. Journal of Smoking Cessation 2015;10:146-53. [DOI: 10.1017/jsc.2014.2l]

\section{Spring 2004 \{published data only\}}

Schneider KL, Spring B, Pagoto SL. Affective benefits of exercise while quitting smoking: influence of smoking-specific weight concern. Psychology of Addictive Behaviors 2007;21(2):255-60

* Spring B, Doran N, Pagoto S, Schneider K, Pingitore R, Hedeker D. Randomized controlled trial for behavioral smoking and weight control treatment: effect of concurrent versus sequential intervention. Journal of Consulting and Clinical Psychology 2004;72(5):785-96. 
Taylor 2005 \{published data only\}

Taylor AH, Katomeri M, Ussher M. Acute effects of self-paced walking on urges to smoke during temporary smoking abstinence. Psychopharmacology (Berl) 2005;181(1):1-7.

Taylor 2006a \{published data only\}

Taylor AH, Katomeri M, Ussher M. Effects of walking on cigarette cravings and affect in the context of Nesbitt's paradox and the circumplex model. Journal of Sport \& Exercise Psychology 2006;28:18-31.

\section{Taylor 2006b \{published data only\}}

Taylor AH, Katomeri M. Effects of a brisk walk on blood pressure responses to the Stroop, a speech task and a smoking cue among temporarily abstinent smokers. Psychopharmacology (Berl) 2006;184(2):247-53

\section{Taylor 2014 \{published data only\}}

Taylor AH, Thompson TP, Greaves CJ, Taylor RS, Green C, Warren FC, et al. A pilot randomised trial to assess the methods and procedures for evaluating the clinical effectiveness and cost-effectiveness of Exercise Assisted Reduction then Stop (EARS) among disadvantaged smokers. Health Technology Assessment 2014;18(4):1-324. [CENTRAL: 978782; CRS: 9400050000000010 ; DOI: 10.3310/hta18040; EMBASE: 2014061892; PUBMED: 24433837]

\section{Thayer 1993 \{published data only\}}

Thayer R, Peters D, Takahaski P, Birkhead-Flight A. Mood and behaviour (smoking and sugar snacking) following moderate exercise: A partial test of self-regulation theory. Personality and Individual Differences 1993;14:97-104.

\section{Toobert 2011 \{published data only\}}

Toobert DJ, Strycker LA, King DK, Barrera M Jr, Osuna D, Glasgow RE. Long-term outcomes from a multiple-risk-factor diabetes trial for Latinas: ¡Viva Bien!. Translational Behavioral Medicine 2011;1(3):416-26.

\section{Treviño 2014 \{published data only\}}

Treviño LA, Baker L, McIntosh S, Mustian K, Seplaki CL, Guido JJ, et al. Physical activity as a coping strategy for smoking cessation in mid-life and older adults. Addictive Behaviors 2014;39:885-888.

\section{Trigwell 2014 \{published data only\}}

Trigwell J, McGee CE, Casstles H, Murphy RC, Porcellato LA, Ussher $\mathrm{M}$, et al. Preventing smoking among nine to ten-yearold children using a novel school-based physical activity intervention: Overview of SmokeFree Sports. Education and Health 2014;32:93-102.

\section{Tritter 2015 \{published data only\}}

Tritter A, Fitzgeorge L, Prapavessis H. The effect of acute exercise on cigarette cravings while using a nicotine lozenge. Psychopharmacology (Berl) 2015;232(14):2531-9.

\section{Ussher 2001 \{published data only\}}

Ussher M, Nunziata P, Cropley M, West R. Effect of a short bout of exercise on tobacco withdrawal symptoms and desire to smoke. Psychopharmacology (Berl) 2001;158(1):66-72.

\section{Ussher 2006 \{published data only\}}

Ussher M, West R, Doshi R, Sampuran AK. Acute effect of isometric exercise on desire to smoke and tobacco withdrawal symptoms. Human Psychopharmacology: Clinical \& Experimental 2006;21(1):39-46.

Ussher 2008 \{published data only\}

Ussher M, Aveyard P, Coleman T, Straus L, West R, Marcus B, et al. Physical activity as an aid to smoking cessation during pregnancy: two feasibility studies. BMC Public Health 2008;8:328

\section{Ussher 2009 \{published data only\}}

Ussher M, Cropley M, Playle S, Mohidin R, West R. Effect of isometric exercise and body scanning on cigarette cravings and withdrawal symptoms. Addiction 2009;104(7):1251-7.

Vander Weg 2008 \{published data only\}

Vander Weg MW, Klesges RC, Ebbert JO, Lichty EJ, Debon M, North F, et al. Trial design: blood pressure control and weight gain prevention in prehypertensive and hypertensive smokers: the treatment and prevention study. Contemporary Clinical Trials 2008;29(2):281-92.

\section{Vickers 2005 \{published data only\}}

Vickers KS, Patten CA, Clark MM, Ebbert JO, Croghan IT, Hathaway JC. Exercise intervention for women with depressive symptoms interested in smoking cessation. Society for Research on Nicotine and Tobacco 11th Annual Meeting, Prague, Czech Republic. 2005.

\section{Vickers 2009 \{published data only\}}

Vickers KS, Patten CA, Lewis BA, Clark MM, Ussher M, Ebbert JO. Feasibility of an exercise counseling intervention for depressed women smokers. Nicotine \& Tobacco Research 2009;11(8):985-95.

\section{Whiteley 2007 \{published data only\}}

Whiteley JA, Napolitano MA, Lewis BA, Williams DM, Albrecht A, Neighbors $\mathrm{CJ}$, et al. Commit to Quit in the YMCAs: translating an evidence-based quit smoking program for women into a community setting. Nicotine \& Tobacco Research 2007;9(11):1227-35.

\section{Williams 2010 \{published data only\}}

Williams DM, Whiteley JA, Dunsiger S, Jennings EG, Albrecht AE, Ussher $\mathrm{MH}$, et al. Moderate intensity exercise as an adjunct to standard smoking cessation treatment for women: a pilot study. Psychology of Addictive Behaviors 2010;24(2):349-54.

Williams 2011 \{published data only\} Williams DM, Dunsiger S, Whitely JA, Ussher MH, Ciccolo JT, Jennings EG. Acute effects of moderate intensity aerobic exercise on affective withdrawal symptoms and cravings among women smoker. Addictive Behaviors 2011;36(8):894-7.

Ybarra 2013 \{published data only\}

Ybarra ML, Holtrop JS, Prescott TL, Rahbar MH, Strong D. Pilot RCT results of stop my smoking USA: a text messagingbased smoking cessation program for young adults. Nicotine \& Tobacco Research 2013;15(8):1388-99. 
Zwick 2006 \{published data only\}

Zwick RH, Mutzbacher P, Dovjak N, Heinzle C, Burghuber OC, Zwick $\mathrm{H}$. Exercise in addition to nicotine replacement therapy improves success rates in smoking cessation. Chest 2006;130:145s

\section{References to ongoing studies}

Ciccolo 2014 \{published data only\}

* Ciccolo JT, Williams DM, Dunsiger SI, Whitworth JW, McCullough AK, Bock BC, et al. Efficacy of resistance training as an aid to smoking cessation:rationale and design of the Strength to Quit study. Mental Health and Physical Activity 2014; Vol. 7:95-103.

NCT01951456. Resistance training as an aid to smoking cessation treatment. clinicaltrials.gov/ct2/show/NCT01951456 (first received 26 September 2013).

\section{NCT00921388 \{published data only\}}

NCT00921388. Exercise for smoking cessation in postmenopausal women. clinicaltrials.gov/show/NCT00921388 (first received 16 June 2009). [CRS: 9400129000001195 ]

\section{NCT02086149 \{published data only\}}

NCT02086149. Aerobic exercise for smokers with depressive symptomatology. clinicaltrials.gov/show/NCT02086149 (first received 13 March 2014). [CRS: 9400129000001193$]$

\section{Pavey 2015 \{published data only\}}

Pavey TG, Gartner CE, Coombes JS, Brown WJ. Assessing the effectiveness of High Intensity Interval Training (HIIT) for smoking cessation in women: HIIT to quit study protocol. BMC Public Health 2015;15:1309.

\section{Smits 2019 \{published data only\}}

Smits JA, Zvolensky MJ, Rosenfield D, Brown RA, Freeman SZ, Dutcher $C D$, et al. YMCA exercise intervention to augment smoking cessation treatment in adults with high anxiety sensitivity: study protocol for a randomized controlled trial. Contemporary Clinical Trials 2019;77:1-7.

\section{Tai-Hing 2016 \{published data only\}}

Tai-Hing L. Short-bout Handgrip Exercise for Smoking Cessation (SHESC). clinicaltrials.gov/ct2/show/NCT02844296 (first received 26 July 2016).

\section{Vander Weg 2018 \{published data only\}}

Vander Weg MW, Coday M, Stockton MB, McClanahan B, Relyea G, Read MC, et al. Community-based physical activity as adjunctive smoking cessation treatment: Rationale, design, and baseline data for the Lifestyle Enhancement Program (LEAP) randomized controlled trial. Contemporary Clinical Trials Communications 2018;9:50-9.

\section{Additional references}

\section{Aaron 1995}

Aaron DJ, Dearwater SR, Anderson R, Olsen T, Kriska AM, Laporte RE. Physical activity and the initiation of high-risk health behaviors in adolescents. Medicine and Science in Sports and Exercise 1995;27(12):1639-45.

\section{Abrantes 2009}

Abrantes AM, Strong DR, Lloyd-Richardson EE, Niaura R, Kahler CW, Brown RA. Regular exercise as a protective factor in relapse following smoking cessation treatment. American Journal on Addictions 2009;18(1):100-1.

\section{Albrecht 1998}

Albrecht AE, Marcus BH, Roberts M, Forman DE, Parisi AF. Effect of smoking cessation on exercise performance in female smokers participating in exercise training. American Journal of Cardiology 1998;82(8):950-5.

\section{Ali 2015}

Ali MM, Amialchuk A, Heller LR. The influence of physical activity on cigarette smoking among adolescents: evidence from Add Health. Nicotine \& Tobacco Research 2015;17(5):539-45.

\section{Allen 2004}

Allen SS, Brintnell DM, Hatsukami D, Reich B. Energy intake and physical activity during short-term smoking cessation in postmenopausal women. Addictive Behaviors 2004;29(5):947-51.

\section{Arbour-Nicitopoulos 2011b}

Arbour-Nicitopoulos KP, Faulkner GE, Cohn TA, Selby P. Smoking cessation in women with severe mental illness: exploring the role of exercise as an adjunct treatment. Archives of Psychiatric Nursing 2011;25(1):43-52.

\section{Bock 1999}

Bock BC, Marcus BH, King TK, Borrelli B, Roberts MR. Exercise effects on withdrawal and mood among women attempting smoking cessation. Addictive Behaviors 1999;24(3):399-410.

\section{Borrelli 2002}

Borrelli B, Hogan JW, Bock B, Pinto B, Roberts M, Marcus B. Predictors of quitting and dropout among women in a clinicbased smoking cessation program. Psychology of Addictive Behaviors 2002;16(1):22-7.

\section{Boutelle 2000}

Boutelle KN, Murray DM, Jeffery RW, Hennrikus DJ, Lando HA. Associations between exercise and health behaviors in a community sample of working adults. Preventive Medicine 2000;30(3):217-24.

\section{Boyle 2000}

Boyle RG, O'Connor P, Pronck N, Tan A. Health behaviors of smokers, ex-smokers, and never smokers in an HMO. Preventive Medicine 2000;31(2 Pt 1):177-82.

\section{CDC 2017}

Babb S, Malarcher A, Schauer G, Asman K, Jamal A (Centers for Disease Control and Prevention). Quitting smoking among adults-United States, 2000-2015. Morbidity and Mortality Weekly Report 2017;65(52):1457-64. 


\section{Colbert 2001}

Colbert LH, Hartman TJ, Malila N, Limburg PJ, Pietinen P, Virtamo J, et al. Physical activity in relation to cancer of the colon and rectum in a cohort of male smokers. Cancer Epidemiology, Biomarkers and Prevention 2001;10(3):265-8.

\section{Cooney 2013}

Cooney GM, Dwan K, Greig CA, Lawlor DA, Rimer J, Waugh FR, et al. Exercise for depression. Cochrane Database of Systematic Reviews 2013, Issue 12. [DOI: 10.1002/14651858.CD004366.pub6]

\section{Coulson 1997}

Coulson NS, Eiser C, Eiser JR. Diet, smoking and exercise: interrelationships between adolescent health behaviours. Child: Care, Health and Development 1997;23(3):207-16.

\section{Daley 2018}

Daley A, Riaz M, Lewis S, Aveyard P, Coleman T, Manyonda I, et al. Physical activity for antenatal and postnatal depression in women attempting to quit smoking: randomised controlled trial. BMC Pregnancy and Childbirth 2018;8:156.

\section{De Ruiter 2006}

De Ruiter W, Faulkner G. Tobacco harm reduction strategies: the case for physical activity. Nicotine \& Tobacco Research 2006;8(2):157-68.

\section{Derby 1994}

Derby CA, Lasater TM, Vass K, Gonzalez S, Carleton RA. Characteristics of smokers who attempt to quit and of those who recently succeeded. American Journal of Preventive Medicine 1994;10(6):327-34.

\section{Deruiter 2008}

Deruiter WK, Faulkner G, Cairney J, Veldhuizen S. Characteristics of physically active smokers and implications for harm reduction. American Journal of Public Health 2008;98(5):925-31.

\section{Dishman 2009}

Dishman RK, O'Connor PJ. Lessons in exercise neurobiology: The case for endorphins. Mental Health and Physical Activity 2009;2(1):4-9.

\section{Doherty 1998}

Doherty SC, Steptoe A, Rink E, Kendrink T, Hilton S. Readiness to change health behaviours among patients at high risk of cardiovascular disease. Journal of Cardiovascular Risk 1998;5(3):147-53.

\section{Emmons 1994}

Emmons KM, Marcus BH, Linnan L, Rossi JS, Abrams DB. Mechanisms in multiple risk factor interventions: Smoking, exercise, and dietary fat intake among manufacturing workers. Preventive Medicine 1994;23(4):481-9.

\section{Escobedo 1993}

Escobedo LG, Marcus SE, Holtzman D, Giovino GA. Sports participation, age at smoking initiation, and the risk of smoking among US high school students. JAMA. 1993;269(11):391-5.

\section{Everson-Hock 2010b}

Everson-Hock ES, Taylor AH, Ussher M, Faulkner G. A qualitative perspective on multiple health behaviour change: views of smoking cessation advisors who promote physical activity. Journal of Smoking Cessation 2010;5:7-14.

\section{Farley 2012}

Farley AC, Hajek P, Lycett D, Aveyard P. Interventions for preventing weight gain after smoking cessation. Cochrane Database of Systematic Reviews 2012, Issue 1. [DOI: 10.1002/14651858.CD006219.pub3]

\section{Faulkner 2007}

Faulkner G, Taylor AH, Munro S, Selby P, Gee C. Exploring the acceptability of physical activity programming within a smoking cessation service for individuals with severe mental illness. Patient Education and Counselling 2007;66:123-6.

\section{Frith 2017}

Frith E, Loprinzi PD. Exercise facilitates smoking cessation indirectly via intention to quit smoking: prospective cohort study among a national sample of young smokers. American Journal of Health Promotion 2018;32(5):1234-8.

\section{Gauthier 2012}

Gauthier AP, Snelling SJ, King M. Thinking Outside the Pack": Examining physically active smokers and implications for practice among Ontario residents. Health Promotion Practice 2012;13(3):395-403.

\section{GBD 2015 Risk Factors Collaborators 2016}

GBD 2015 Risk Factors Collaborators. Global, regional,and national comparative risk assessment of 79 behavioural,environmental and occupational, and metabolic risks or clusters of risks, 1990-2015: a systematic analysis for the Global Burden of Disease Study 2015. Lancet 2016;388(10053):1659-724.

\section{Giatras 2017}

Giatras N, Wanninkhof E, Leontowitsch M, Lewis B, Taylor A, Cooper S, et al. Lessons learned from the London Exercise and Pregnant (LEAP) Smokers randomised controlled trial process evaluation: implications for the design of physical activity for smoking cessation interventions during pregnancy. BMC Public Health 2017;17(1):85.

\section{Glowaski 2018}

Glowacki K, Priebe CS, O'Neill M, Faulkner G. When you put the group and the running together...': a qualitative examination of participant and coach experiences of the Canadian Run to Quit program. Journal of Smoking Cessation 2018;14:52-58.

\section{Haasova 2013}

Haasova M, Warren FC, Ussher M, Janse Van Rensburg K, Faulkner G, Cropley M, et al. The acute effects of physical activity on cigarette cravings: systematic review and meta-analysis with individual participant data. Addiction 2013;108(1):26-37. 


\section{Haasova 2014}

Haasova M, Warren FC, Ussher M, Janse Van Rensburg, K, Faulkner G, Cropley M, et al. The acute effects of physical activity on cigarette cravings: Exploration of potential moderators, mediators and physical activity attributes using individual participant data (IPD) meta-analyses. Psychopharmacology (Berl) 2014;231(7):1267-75.

\section{Haasova 2016}

Haasova M, Warren FC, Thompson T, Ussher M, Taylor AH. The association between habitual physical activity and cigarette cravings, and influence of smokers' characteristics in disadvantaged smokers not ready to quit. Psychopharmacology (Berl) 2016;233(14):2765-74.

\section{Haddock 2000}

Haddock CK, O'Byrne KK, Klesges RC, Talcott W, Lando H, Peterson AL. Relapse to smoking after basic military training in the U.S. Air Force. Military Medicine 2000;165(11):884-8.

\section{Hall 1989}

Hall SM, McGee R, Tunstall C, Duffy J, Benowitz N. Changes in food intake and activity after quitting smoking. Journal of Consulting and Clinical Psychology 1989;57(1):81-6.

\section{Hedblad 1997}

Hedblad B, Ogren M, Isacsson SO, Janzo L. Reduced cardiovascular mortality risk in male smokers who are physically active; Results from a 25-year follow-up of the prospective population study of men born in 1914. Archives of Internal Medicine 1997;157(8):893-9.

\section{Higgins 2003}

Higgins JP, Thompson SG, Deeks JJ, Altman DG. Measuring inconsistency in meta-analyses. BMJ 2003;327(7414):557-60.

\section{Higgins 2011}

Higgins JP, Altman DG, Gøtzsche PC, Jüni P, Moher D, Oxman AD, et al. Cochrane Bias Methods Group, Cochrane Statistical Methods Group. The Cochrane Collaboration's tool for assessing risk of bias in randomised trials. BMJ 2011; Vol. 343:d5928.

\section{Higgins 2017}

Higgins JP, Altman DG, Sterne JAC, editor(s). Chapter 8: Assessing risk of bias in included studies. In: Higgins JP, Churchill R, Chandler J, Cumpston MS, editor(s), Cochrane Handbook for Systematic Reviews of Interventions version 5.2.0 (updated June 2017), The Cochrane Collaboration, 2017. Available from www.training.cochrane.org/handbook.

\section{Hu 2002}

Hu G, Pekkarinen H, Hanninen O, Yu Z, Guo Z, Tian H. Commuting, leisure-time physical activity, and cardiovascular risk factors in China. Medicine and Science of Sports and Exercise 2002;34(2):234-8.

\section{Hyman 2007}

Hyman DJ, Pavlik VN, Taylor WC, Goodrick GK, Moye L. Simultaneous vs sequential counseling for multiple behavior change. Archives of Internal Medicine 2007;167(11):1152-8.

\section{James 2016}

James E, Freund M, Booth A, Duncan MJ, Johnson N, Short CE, et al. Comparative efficacy of simultaneous versus sequential multiple health behavior change interventions among adults: a systematic review of randomised trials. Preventive Medicine 2016;89:211-23.

\section{Jha 2011}

Jha P. Avoidable deaths from smoking: a global perspective. Public Health Reviews 2011;33:569-600.

\section{Kaczynski 2008}

Kaczynski AT, Manske SR, Mannell RC, Grewal K. Smoking and physical activity: a systematic review. American Journal of Health Behavior 2008;32(1):93-110.

\section{King 1996}

King TK, Marcus BH, Pinto BM, Emmons KM, Abrams DB. Cognitive behavioural mediators of changing multiple behaviours: Smoking and a sedentary lifestyle. Preventive Medicine 1996;25:684-91.

\section{Klinsophon 2017}

Klinsophon T, Thaveeratitham P2, Sitthipornvorakul E, Janwantanakul P. Effect of exercise type on smoking cessation a meta-analysis of randomized controlled trials. BMC Research Notes 2017;10(1):442.

\section{Korhonen 2011}

Korhonen T, Goodwin A, Miesmaa P, Dupuis EA, Kinnunen T. Smoking cessation program with exercise improves cardiovascular disease biomarkers in sedentary women. Journal of Womens Health 2011;20(7):1051-64.

\section{Koubaa 2015}

Koubaa A, Triki M, Trabelsi H, Baati H, Sahnoun Z, Hakim A. The effect of a 12-week moderate intensity interval training program on the antioxidant defense capability and lipid profile in men smoking cigarettes or hookah: a cohort study. The Scientific World Journal 2015;Article ID 639369:1-9.

\section{Leitzmann 2009}

Leitzmann MF, Koebnick C, Abnet CC, Freedman ND, Park Y, Hollenbeck A, et al. Prospective study of physical activity and lung cancer by histologic type in current, former, and never smokers. American Journal of Epidemiology 2009;169(5):542-53.

\section{Loprinzi 2014}

Loprinzi PD, Walker JF, Kane C, Cardinal BJ. Physical activity moderates the association between nicotine dependence and depression among U.S. smokers. American Journal of Health Promotion 2014;29(1):37-42.

\section{Loprinzi 2016}

Loprinzi PD, Walker JF. Association of longitudinal changes of physical activity on smoking cessation among young daily smokers. Journal of Physical Activity \& Health 2016;13(1):1-5.

\section{Lycett 2011}

Lycett $\mathrm{D}$, Munafò M, Johnstone E, Murphy M, Aveyard P. Associations between weight change over 8 years and baseline 
body mass index in a cohort of continuing and quitting smokers. Addiction 2011;106(1):188-96.

\section{López-Torrecillas 2014}

López-Torrecillas F, Rueda MM, López-Quirantes EM, Santiago JM, Tapioles RR. Adherence to treatment to help quit smoking: effects of task performance and coping with withdrawal symptoms. BMC Public Health 2014;14:1217.

\section{McDermot 2009}

McDermot L, Dobson A, Owen N. Determinants of continuity and change over 10 years in young women's smoking. Addiction 2009;104(3):478-87.

\section{Metheny 1998}

Metheny KB, Weatherman KE. Predictors of smoking cessation and maintenance. Journal of Clinical Psychology 1998;54(2):223-35.

\section{Paavola 2001}

Paavola M, Vartianen E, Puska P. Smoking cessation between teenage years and adulthood. Health Education Research 2001;16(1):49-57.

\section{Pate 1996}

Pate RR, Heath GW, Dowda M, Trost SG. Associations between physical activity and other health behaviors in a representative sample of US adolescents. American Journal of Public Health 1996;86(11):1577-81.

\section{Patten 2003}

Patten CA, Vickers KS, Martin JE, Williams CD. Exercise interventions for smokers with a history of alcoholism: Exercise adherence rates and effect of depression on adherence. Addictive Behaviors 2003;28:657-67.

\section{Patten 2018}

Patten C, Levine J, Pavlidis I, Balls-Berry J, Shah A, Hughes C, et al. Survey of potential receptivity to robotic-assisted exercise coaching in a diverse sample of smokers and nonsmokers. PLOS One 2018;13:e0197090.

\section{Peretti-Watel 2002}

Peretti-Watel P, Beck F, Legleye S. Beyond the U-curve: the relationship between sport and alcohol, cigarette and cannabis use in adolescents. Addiction 2002;97(6):707-16

\section{Picavet 2010}

Picavet HS, Wendel-vos GC, Vreeken HL, Schuit AJ, Verschuren WM. How stable are physical activity habits among adults? The Doetinchem Cohort Study. Medicine and Science in Sports and Exercise 2010;43(1):74-9.

\section{Raw 1998}

Raw M, McNeill A, West R. Smoking cessation guidelines for health professionals: A guide to effective smoking cessation interventions for the health care system. London: HEA, 1998.

\section{Roberts 2012}

Roberts V, Maddison R, Simpson C, Bullen C, Prapavessis H. The acute effects of exercise on cigarette cravings, withdrawal symptoms, affect, and smoking behaviour: systematic review update and meta-analysis. Psychopharmacology (Berl) 2012;222(1):1-15.

\section{Rodriguez 2004}

Rodriguez D, Audrain-McGovern J. Team sport participation and smoking: analysis with general growth mixture modeling. Journal of Pediatric Psychology 2004;29(4):299-308.

\section{Rodriguez 2008}

Rodriguez D, Dunton GF, Tcherne J, Sass J. Physical activity and adolescent smoking: A moderated mediation model. Mental Health and Physical Activity 2008;1:17-25.

\section{Russell 1983}

Russell PO, Epstein LH, Erickson KT. Effects of acute exercise and cigarette smoking on autonomic and neuromuscular responses to a cognitive stressor. Psychological Reports 1983;53(1):199-206.

\section{Schuman 2001}

Schumann A, Hapke U, Rumpf HJ, Meyer C, John U. The association between degree of nicotine dependence and other health behaviours. Findings from a German general population study. European Journal of Public Health 2001;11(4):450-2.

\section{Schünemann 2017}

Schünemann HJ, Oxman AD, Higgins JP, Vist GE, Glasziou P, Akl E, et al. on behalf of the Cochrane GRADEing Methods Group and the Cochrane Statistical Methods Group. Chapter 11: Completing 'Summary of findings' tables and grading the confidence in or quality of the evidence. In: Higgins JP, Churchill R, Chandler J, Cumpston MS, editor(s), Cochrane Handbook for Systematic Reviews of Interventions version 5.2.0 (updated June 2017). The Cochrane Collaboration, 2017. Available from www.training.cochrane.org/handbook.

\section{Scioli 2009}

Scioli ER, Biller H, Rossi J, Riebe D. Personal motivation, exercise, and smoking behaviors among young adults. Behavioral Medicine 2009;35(2):57-64.

\section{Sedgwick 1988}

Sedgwick AW, Davidson AH, Taplin RE, Thomas DW. Effects of physical activity on risk factors for coronary heart disease in previously sedentary women: A five-year longitudinal study. Australian and New Zealand Journal of Medicine 1988;18(4):600-5.

\section{Senti 2001}

Senti M, Elosua R, Tomás M, Sala J, Masiá R, Ordovás JM, et al. Physical activity modulates the combined effect of a common variant of the lipoprotein lipase gene and smoking on serum triglyceride levels and high-density lipoprotein cholesterol in men. Human Genetics 2001;109(4):385-92.

\section{Shinton 1997}

Shinton R. Lifelong exposures and the potential for stroke prevention: The contribution of cigarette smoking, exercise and body fat. Journal of Epidemiology and Community Health 1997;51(2):138-43. 


\section{Siahpush 2019}

Siahpush M, Levan TD, Nguyen MN, Grimm BL, Ramos AK, Michaud TL, et al. Association of physical activity and mortality risk reduction among smokers: results from 1998-2009 national health interview surveys-national death index linkage. Journal of Physical Activity and Health 2019;16(10):865-71.

\section{Spring 2009}

Spring B, Howe D, Berendsen M, McFadden HG, Hitchcock K, Rademaker AW, et al. Behavioral intervention to promote smoking cessation and prevent weight gain: a systematic review and meta-analysis. Addiction 2009;104(9):1472-86.

\section{Steptoe 2006}

Steptoe A, Ussher M. Smoking, cortisol and nicotine. International Journal of Psychophysiology 2006;59(3):228-35.

\section{Swan 2018}

Swan JH, Brooks JM, Amini R, Moore AR, Turner KW. Smoking predicting physical activity in an aging America. Journal of Nutrition, Health and Aging 2018;22(4):476-82.

\section{Takemura 2000}

Takemura Y, Sakurai Y, Inaba Y, Kugai N. A cross-sectional study on the relationship between leisure or recreational physical activity and coronary risk factors. Tohoku Journal of Experimental Medicine 2000;192(3):227-37.

\section{Taylor 2007a}

Taylor AH, Katomeri M. Walking reduces cue-elicited cigarette cravings and withdrawal symptoms, and delays ad libitum smoking. Nicotine \& Tobacco Research 2007;9(11):1183-90.

\section{Taylor 2007b}

Taylor AH, Ussher MH, Faulkner G. The acute effects of exercise on cigarette cravings, withdrawal symptoms, affect and smoking behaviour: A systematic review. Addiction 2007;102(4):534-43.

\section{Taylor 2010}

Taylor AH, Everson-Hock ES, Ussher M. Integrating the promotion of physical activity within a smoking cessation programme: findings from collaborative action research in UK Stop Smoking Services. BMC Health Services Research 2010;10:317.

\section{Teo 2014}

Teo AA, Allen AM, Allen SS, Oncken C. Impact of exercise on changing food cravings in postmenopausal women during smoking cessation. Proceedings of Society for Research on Nicotine and Tobacco Annual Conference, Seattle, USA. 2014.

\section{Vander Weg 2001}

Vander Weg MW, Klesges RC, Eck Clemens LH, Meyers AW, Pascale RW. The relationship between ethnicity, gender, and

\section{CHARACTERISTICS OF STUDIES}

Characteristics of included studies [ordered by study ID] short-term changes in energy balance following smoking cessation. International Journal of Behavioral Medicine 2001;8:163-77.

\section{Verkooijen 2008}

Verkooijen KT, Nielsen GA, Kremers SP. The association between leisure time physical activity and smoking in adolescence: an examination of potential mediating and moderating factors. International Journal of Behavioural Medicine 2008;15(2):157-63.

\section{Vickers 2003}

Vickers KS, Patten CA, Lane K, Clark MM, Croghan IT, Schroeder DR, et al. Depressed versus nondepressed young adult tobacco users: differences in coping style, weight concerns and exercise level. Health Psychology 2003;22(5):498-503.

\section{Ward 2003}

Ward KD, Vander Weg MW, Klesges RC, Kovach KW, Elrod MC, DeBon $\mathrm{M}$, et al. Characteristics of highly physically active smokers in a population of young adult military recruits. Addictive Behaviors 2003;28(8):1405-18.

\section{West 2005}

West R, Hajek P, Stead L, Stapleton J. Outcome criteria in smoking cessation trials: proposal for a common standard. Addiction 2005;100(3):299-303.

\section{Williams 2008}

Williams DM. Increasing fitness is associated with fewer depressive symptoms during successful smoking abstinence among women. International Journal of Fitness 2008;4(1):39-44.

\section{References to other published versions of this review \\ Ussher 2000a}

Ussher MH, Taylor AH, West R, McEwen A. Does exercise aid smoking cessation? A systematic review. Addiction 2000;95(2):199-208.

\section{Ussher 2000b}

Ussher M, West R, Taylor AH, McEwen A. Exercise interventions for smoking cessation. Cochrane Database of Systematic Reviews 2000, Issue 3. [DOI: 10.1002/14651858.CD002295]

\section{Ussher 2005}

Ussher M. Exercise interventions for smoking cessation. Cochrane Database of Systematic Reviews 2005, Issue 1. [DOI: 10.1002/14651858.CD002295.pub2]

* Indicates the major publication for the study 
Abrantes 2014

\begin{tabular}{|c|c|}
\hline Methods & $\begin{array}{l}\text { Country: USA } \\
\text { Randomisation: Computer-generated, using URN procedure }\end{array}$ \\
\hline Participants & 61 participants, $65.6 \%$ female, mean age 47 , mean CPD 20, FTCD score 5.8 , "physically inactive" \\
\hline Interventions & $\begin{array}{l}\text { (a) Intervention: CV equipment: facility, began at } 20 \text { mins per session with weekly gradual increases, } \\
55 \%-69 \% \text { of age-predicted maximal heart rate (once a week for } 12 \text { weeks) + group PA counselling } \\
\text { (once a week for } 12 \text { weeks) + telephoned-based CP (once a week for } 8 \text { weeks), including nicotine patch- } \\
\text { es for } 8 \text { weeks } \\
\text { (b) Control: health education (once a week for } 12 \text { weeks) + CP as (a) } \\
\text { Exercise began before quit date } \\
\text { Both groups received financial incentives to attend }\end{array}$ \\
\hline
\end{tabular}

Outcomes Continuous abstinence

Validation: $\mathrm{CO}<10 \mathrm{ppm}$. Where $\mathrm{CO}$ not available, significant other reports were used for 1 participant at the 6-month follow-up and 1 participant at the 12-month follow-up

Follow-up: end of treatment, 6 months, 12 months

\begin{tabular}{ll}
\hline Notes & Contact time balanced between (a) and (b) \\
& Funding: This work was supported by a National Institute on Drug Abuse-funded grant (K23 DA019950) \\
awarded to Dr. AMA \\
Conflict of interest: None declared
\end{tabular}

\section{Risk of bias}

\begin{tabular}{|c|c|c|}
\hline Bias & Authors' judgement & Support for judgement \\
\hline $\begin{array}{l}\text { Random sequence genera- } \\
\text { tion (selection bias) }\end{array}$ & Low risk & Computer-generated \\
\hline $\begin{array}{l}\text { Allocation concealment } \\
\text { (selection bias) }\end{array}$ & Unclear risk & No information \\
\hline $\begin{array}{l}\text { Blinding of outcome as- } \\
\text { sessment (detection bias) } \\
\text { All outcomes }\end{array}$ & Low risk & $\begin{array}{l}\text { Details of blinding not specified. However as self-reports of smoking were vali- } \\
\text { dated objectively by expired CO risk is considered as low }\end{array}$ \\
\hline $\begin{array}{l}\text { Incomplete outcome data } \\
\text { (attrition bias) } \\
\text { All outcomes }\end{array}$ & Low risk & $\begin{array}{l}\text { ITT analysis. Number of missing self-reports counted as smoking is not stated. } \\
\text { Only } 5 \text { lost to follow-up }\end{array}$ \\
\hline $\begin{array}{l}\text { Selective reporting (re- } \\
\text { porting bias) }\end{array}$ & Low risk & Smoking outcomes reported as stated in Methods \\
\hline
\end{tabular}

Bernard 2015

$\begin{array}{ll}\text { Methods } & \text { Country: France } \\ & \text { Randomisation: Computer-generated }\end{array}$


Bernard 2015 (Continued)

Participants
70 participants, 59\% female, mean age 48, mean CPD 21, mean FTND score 6.4, engaged in physical activity for $<3$ days a week for $\geq 20$ mins, current depressive symptoms defined as a score of $>8$ on the depression subscale of the Hospital Anxiety and Depression Scale, $7 \%$ diagnosed with a major depressive disorder, 39\% with dysthymia (persistent mild depression)
Interventions (a) Exercise intervention: 40 mins group-based at facility, supervised cycle ergometry at $60 \%$ - $85 \%$ maximum heart rate, twice a week for 2 weeks, then once a week for 6 weeks plus home-based exercise once a week, plus 40 mins physical activity counselling alternative weeks + CP ( 1 brief initial brief counselling session, then 40 mins smoking cessation counselling alternative weeks for 8 weeks, plus 12 weeks of NRT or varenicline)

(b) Control: health education (group-based and matched for contact time with (a)) +1 brief initial brief counselling session and 12 weeks of NRT or varenicline

Notes
Control group balanced with exercise group for contact time. Limitations: small sample size, the exer-
only received 1 brief session of cessation counselling, low follow-up rate, no record of exercise outside
of supervised exercise, over $2 / 3$ of participants were taking antidepressant medication, limiting the po-
tential of the exercise intervention influence depression
Funding: This work was supported by the University Hospital of Montpellier (AOI 2009) and French
Committee against Respiratory Diseases.
Declared COIs: Pr Quantin received research funds and served on the scientific board of Lilly, Bohringer,
Roche, and Pfizer. Pr Courtet has received grants and served as consultant or speaker for the follow-
ing entities: AstraZeneca, Roche, Servier, Bristol-Myers Squibb, Janssen-Cilag, Lundbeck, Otsuka,
Pfizer, Sanofi- Aventis, and Servier. Dr. Guillaume has received compensation as a consultant for As-
traZeneca, Bristol-Myers Squibb, Lundbeck, Otsuka, Servier, and Janssen Cilag. These companies man-
ufacture and/or distribute some antidepressant, mood stabilizer, and/or antipsychotic medications.
Drs. Bernard, Cyprien, and Georgescu have no conflict of interest. Pr Ninot and Taylor have no conflict
of interest.

\section{Risk of bias}

\begin{tabular}{lll}
\hline Bias & Authors' judgement & Support for judgement \\
\hline $\begin{array}{l}\text { Random sequence genera- } \\
\text { tion (selection bias) }\end{array}$ & Low risk & Computer-generated \\
\hline $\begin{array}{l}\text { Allocation concealment } \\
\text { (selection bias) }\end{array}$ & Low risk & $\begin{array}{l}\text { Allocation to treatment conditions was unknown to the study staff or investi- } \\
\text { gators prior to assignments }\end{array}$ \\
\hline $\begin{array}{l}\text { Blinding of outcome as- } \\
\text { sessment (detection bias) } \\
\text { All outcomes }\end{array}$ & Low risk & $\begin{array}{l}\text { Researchers conducting the follow-ups were aware of group allocation but low } \\
\text { risk of bias as self-reports were validated objectively by expired CO }\end{array}$ \\
\hline $\begin{array}{l}\text { Incomplete outcome data } \\
\text { (attrition bias) } \\
\text { All outcomes }\end{array}$ & High risk & $\begin{array}{l}\text { Less than half (42\%) of those randomised were followed up at 52 weeks. ITT } \\
\text { approach. Not clear whether missing data were classified as smoking }\end{array}$ \\
\hline $\begin{array}{l}\text { Selective reporting (re- } \\
\text { porting bias) }\end{array}$ & Low risk & All outcomes stated in Methods were reported \\
\hline
\end{tabular}


Bize 2010

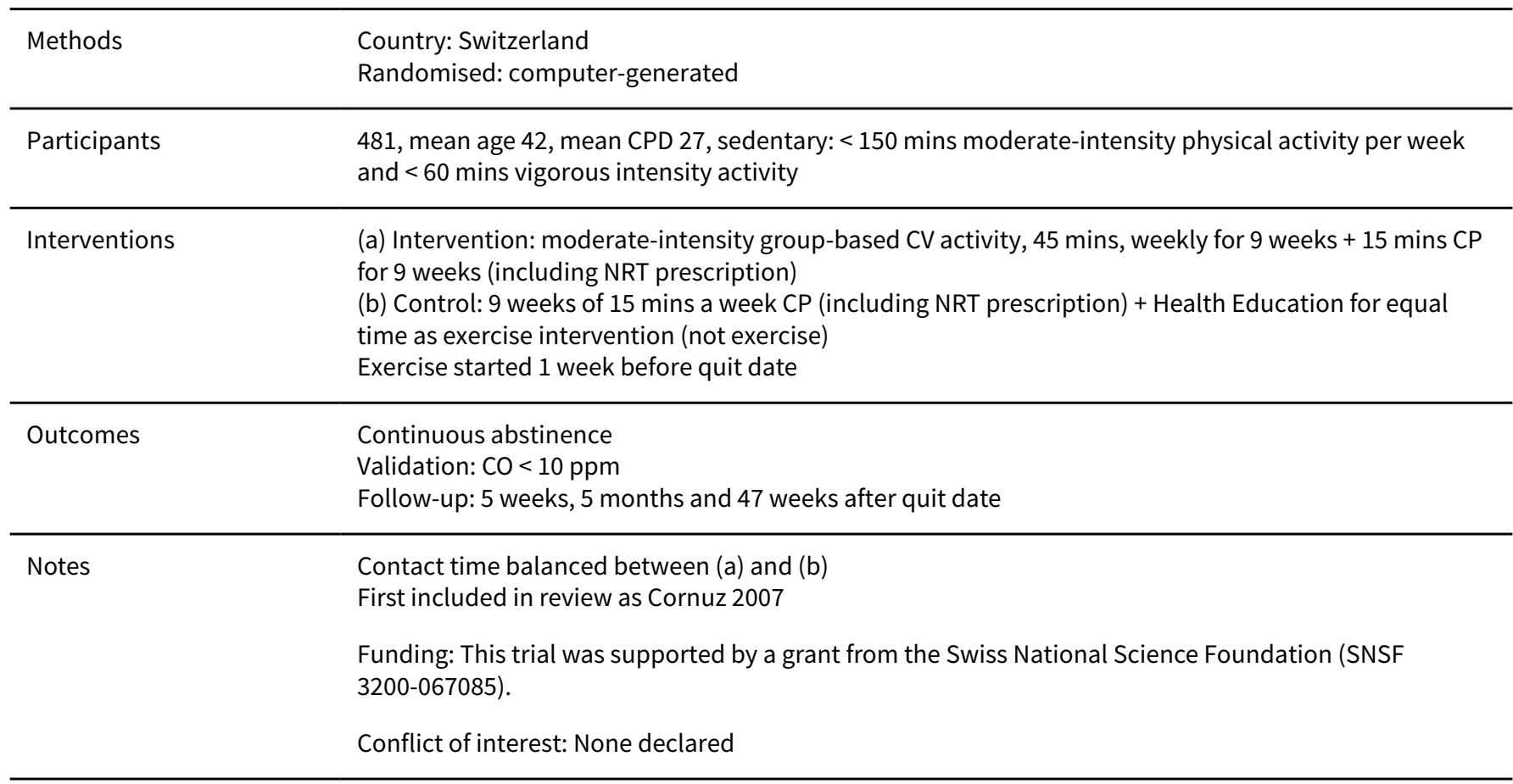

\section{Risk of bias}

\begin{tabular}{|c|c|c|}
\hline Bias & Authors' judgement & Support for judgement \\
\hline $\begin{array}{l}\text { Random sequence genera- } \\
\text { tion (selection bias) }\end{array}$ & Low risk & Quote: "Remotely and randomly generated by a computer", block size 50 \\
\hline $\begin{array}{l}\text { Allocation concealment } \\
\text { (selection bias) }\end{array}$ & Low risk & $\begin{array}{l}\text { Quote: "Concealment of allocation was secured by means of sealed en- } \\
\text { velopes." }\end{array}$ \\
\hline & & $\begin{array}{l}\text { Comment: Not stated whether those delivering the intervention were aware of } \\
\text { the possible treatment allocations }\end{array}$ \\
\hline $\begin{array}{l}\text { Blinding of outcome as- } \\
\text { sessment (detection bias) } \\
\text { All outcomes }\end{array}$ & Low risk & $\begin{array}{l}\text { Outcome assessment was not blinded, but as self-reports of smoking were val- } \\
\text { idated objectively by expired CO risk is considered as low }\end{array}$ \\
\hline $\begin{array}{l}\text { Incomplete outcome data } \\
\text { (attrition bias) } \\
\text { All outcomes }\end{array}$ & High risk & $\begin{array}{l}62 \text { post-randomisation exclusions: } 11 \text { Int and } 2 \text { Cont did not attend first group } \\
\text { session, } 1 \text { Cont pregnant, } 20 \text { Int and } 28 \text { Cont regular exercisers, or marijuana } \\
\text { users. } 45 \% \text { Int and } 38 \% \text { Cont lost to follow-up at } 1 \text { year, included as smokers in } \\
\text { analysis }\end{array}$ \\
\hline $\begin{array}{l}\text { Selective reporting (re- } \\
\text { porting bias) }\end{array}$ & Low risk & Smoking outcomes reported as stated in Methods \\
\hline
\end{tabular}

\section{Ciccolo 2011}

\begin{tabular}{ll}
\hline Methods & Country: USA \\
& Randomisation: computer-generated list of numbers
\end{tabular}

Participants $\quad 26,52 \%$ female, mean age 37 (36.5), mean CPD 18, exercise $\leq 60$ mins/week


Ciccolo 2011 (Continued)

Interventions

(a) Resistance training with equipment: alone, facility, 60 mins, 2 times/week for 12 weeks, 10 exercises, 65\% - 75\% est max, 10 reps, weeks 1 - 3: 1 set, weeks 4 - 12: 2 sets, + CP (single 1 - 20-min counselling + nicotine patches, received prior to randomisation)

(b) CP as (a), + health education video, 25 mins, twice/week for 12 weeks

Exercise began on the quit day

\begin{tabular}{|c|c|}
\hline Outcomes & $\begin{array}{l}\text { 7-day PPA, prolonged abstinence (allowing 2-week grace period after quitting) } \\
\text { Validation: } \mathrm{CO}<10 \mathrm{ppm} \\
\text { Follow-up: } 3,6 \text { months }\end{array}$ \\
\hline \multirow[t]{4}{*}{ Notes } & Number of contacts balanced between (a) and (b) but contact time was not \\
\hline & $\begin{array}{l}\text { Following } 4 \times 30 \text {-min pre-randomisation sessions (orientation, consent and baseline questionnaires), } \\
\text { over a 2-week run-in period, } 147 \text { were excluded }\end{array}$ \\
\hline & Funding: National Cancer Institute (R03 CA132475 to JTC) \\
\hline & Conflict of interest: None declared \\
\hline
\end{tabular}

\section{Risk of bias}

\begin{tabular}{lll}
\hline Bias & Authors' judgement & Support for judgement \\
\hline $\begin{array}{l}\text { Random sequence genera- } \\
\text { tion (selection bias) }\end{array}$ & Low risk & Randomly generated by a computer \\
\hline $\begin{array}{l}\text { Allocation concealment } \\
\text { (selection bias) }\end{array}$ & Unclear risk & No detail given \\
\hline $\begin{array}{l}\text { Blinding of outcome as- } \\
\text { sessment (detection bias) } \\
\text { All outcomes }\end{array}$ & Low risk & $\begin{array}{l}\text { Details of blinding not specified, but as self-reports of smoking were validated } \\
\text { objectively by expired CO risk is considered as low }\end{array}$ \\
\hline $\begin{array}{l}\text { Incomplete outcome data } \\
\text { (attrition bias) } \\
\text { All outcomes }\end{array}$ & Low risk & $\begin{array}{l}1 \text { post-randomisation exclusion: developed lung cancer } \\
8 \% \text { Int and 15\% Cont lost to follow-up at 3 months, 38\% Int and 54\% Cont lost } \\
\text { to follow-up at 6 months; all included as smokers in analysis }\end{array}$ \\
\hline $\begin{array}{l}\text { Selective reporting (re- } \\
\text { porting bias) }\end{array}$ & Low risk & Smoking outcomes reported as stated in Methods \\
\hline
\end{tabular}

Hassandra 2017

\begin{tabular}{ll}
\hline Methods & $\begin{array}{l}\text { Country: Finland } \\
\text { Randomisation: online randomisation tool }\end{array}$ \\
\hline Participants & 44 participants, $43 \%$ female, mean age 39, smoking $>10 \mathrm{CPD}$, mean BMI $26 \mathrm{~kg} / \mathrm{m}^{2}$ \\
\hline Interventions & $\begin{array}{l}\text { All participants received } 3 \text { weekly, group smoking-cessation counselling sessions before setting a quit } \\
\text { date and before being randomised to intervention or control. Those who missed a group session were } \\
\text { offered an individual session. Within } 3 \text { to } 7 \text { days after their quit day, all participants had a } 4 \text { th session of } \\
\text { group training on relapse prevention and formed action plans to cope with cravings. In addition the in- } \\
\text { tervention group downloaded an app to their mobile phone and were given instructions on how to use } \\
\text { it. The app gave messages about which physical activities to do to help them reduce cravings and how } \\
\text { to do the activities. The app also gave general messages about smoking cessation } \\
\text { Cessation programme began before quit date. Exercise began after quit date }\end{array}$
\end{tabular}


Hassandra 2017 (Continued)

Outcomes

7-day PP self-reported abstinence at 3 days and 1, 2, 3, 4, 12, and 24 weeks ( 6 months after starting cessation programme) after the quit date

Notes

Small sample, as feasibility study. Low usage of app. The intervention group had more smoking cessation support than the control, as the app included general messages about smoking cessation and motivation, as well as messages about exercise. Self-reports of abstinence were not validated

Funding: The study was funded by the Finnish National Institute for Health and Welfare (Terveyden ja Hyvinvoinnin Laitos)

Conflict of interest: None declared

\section{Risk of bias}

\begin{tabular}{lll}
\hline Bias & Authors' judgement & Support for judgement \\
\hline $\begin{array}{l}\text { Random sequence genera- } \\
\text { tion (selection bias) }\end{array}$ & Low risk & Online randomisation tool \\
\hline $\begin{array}{l}\text { Allocation concealment } \\
\text { (selection bias) }\end{array}$ & Low risk & $\begin{array}{l}\text { Allocation to treatment conditions was unknown to the study staff or investi- } \\
\text { gators prior to assignments }\end{array}$ \\
\hline $\begin{array}{l}\text { Blinding of outcome as- } \\
\text { sessment (detection bias) } \\
\text { All outcomes }\end{array}$ & Low risk & $\begin{array}{l}\text { Follow-ups were conducted by online questionnaire, risk of differential misre- } \\
\text { port judged to be low }\end{array}$ \\
\hline $\begin{array}{l}\text { Incomplete outcome data } \\
\text { (attrition bias) } \\
\text { All outcomes }\end{array}$ & Low risk & $\begin{array}{l}77 \% \text { of those randomised were followed up at } 6 \text { months. Used an ITT ap- } \\
\text { proach, with those lost to follow-up counted as having relapsed to smoking }\end{array}$ \\
\hline $\begin{array}{l}\text { Selective reporting (re- } \\
\text { porting bias) }\end{array}$ & Low risk & Outcomes stated in protocol were reported \\
\hline
\end{tabular}

Hill 1985

\begin{tabular}{ll}
\hline Methods & $\begin{array}{l}\text { Country: Canada } \\
\text { Randomised }\end{array}$ \\
\hline Participants & 26 women, 10 men, mean age 40, mean CPD 32 \\
\hline Interventions & $\begin{array}{l}\text { (a) Intervention: CV activity: various, group, facility, 30 mins, twice weekly for } 5 \text { weeks + home activity + } \\
\text { CP twice weekly for } 5 \text { weeks } \\
\text { (b) Control, CP alone } \\
\text { Exercise began on quit date }\end{array}$ \\
\hline Outcomes & $\begin{array}{l}\text { 7-day PPA } \\
\text { Validation: CO } \\
\text { Follow-up: 1, 3, } 6 \text { months }\end{array}$ \\
\hline Cotes & Contact time not balanced \\
& Funding: Information not provided. \\
Conflict of interest: Information not provided
\end{tabular}

\section{Risk of bias}

Exercise interventions for smoking cessation (Review) 
Hill 1985 (Continued)

\begin{tabular}{lll} 
Bias & Authors' judgement & Support for judgement \\
\hline $\begin{array}{l}\text { Random sequence genera- } \\
\text { tion (selection bias) }\end{array}$ & Unclear risk & Method not stated \\
\hline $\begin{array}{l}\text { Allocation concealment } \\
\text { (selection bias) }\end{array}$ & Unclear risk & No details given \\
\hline $\begin{array}{l}\text { Blinding of outcome as- } \\
\text { sessment (detection bias) } \\
\text { All outcomes }\end{array}$ & High risk & Self-reported smoking status was not validated objectively \\
\hline $\begin{array}{l}\text { Incomplete outcome data } \\
\text { (attrition bias) } \\
\text { All outcomes }\end{array}$ & Low risk & 1 participant not attending follow-ups was counted as a smoker \\
\hline $\begin{array}{l}\text { Selective reporting (re- } \\
\text { porting bias) }\end{array}$ & Low risk & Smoking outcomes reported as stated in Methods \\
\hline
\end{tabular}

Hill 1993

$\begin{array}{ll}\text { Methods } & \text { Country: USA } \\ & \text { Recruitment: community volunteers, smoking at least } 30 \text { yrs, not currently walking for exercise } \\ & \text { Randomisation: in blocks of } 8 \text { to } 12, \text { method not described }\end{array}$

Randomisation: in blocks of 8 to 12 , method not described

\begin{tabular}{ll}
\hline Participants & 82 (43 women, 39 men), mean age 59, mean CPD 28, ir \\
\hline Interventions & $\begin{array}{l}\text { (a) Intervention 1: Walk: group/individual, facility/hom } \\
\text { times/week for } 12 \text { weeks }(\mathrm{n}=20) \\
\text { (b) Intervention 2: as (a) }+ \text { CP } 1-4 \text { times/week for } 12 \text { w } \\
\text { (c) Intervention 3: CP as (b) + nicotine gum ( }=22) \\
\text { (d) Control: CP alone ( } \mathrm{n}=22) \\
\text { Exercise began before quit date }\end{array}$ \\
\hline Outcomes & 5-day PPA \\
Validation: CO $<10$ ppm \\
Follow-up: $1,4,9$ months \\
(b) compared to (d) for effect of exercise programme \\
Funding: Information not provided \\
Conflict of interest: Information not provided
\end{tabular}

\section{Risk of bias}

\begin{tabular}{lll}
\hline Bias & Authors' judgement & Support for judgement \\
\hline $\begin{array}{l}\text { Random sequence genera- } \\
\text { tion (selection bias) }\end{array}$ & Unclear risk & Method not stated \\
\hline $\begin{array}{l}\text { Allocation concealment } \\
\text { (selection bias) }\end{array}$ & Low risk & No details given \\
\hline $\begin{array}{l}\text { Blinding of outcome as- } \\
\text { sessment (detection bias) }\end{array}$ & Low risk & $\begin{array}{l}\text { Details of blinding not specified, but as self-reports of smoking were validated } \\
\text { objectively by expired CO risk is considered as low }\end{array}$ \\
\hline
\end{tabular}


Hill 1993 (Continued)

All outcomes

\begin{tabular}{|c|c|c|}
\hline $\begin{array}{l}\text { Incomplete outcome data } \\
\text { (attrition bias) }\end{array}$ & Low risk & $\begin{array}{l}4 \text { individuals dropped out and were excluded from the analysis. The main find- } \\
\text { ings were the same with or without the } 4 \text { dropouts }\end{array}$ \\
\hline
\end{tabular}

All outcomes

ings were the same with or without the 4 dropouts

Selective reporting (re- Low risk Smoking outcomes reported as stated in Methods
porting bias)

porting bias)

Kinnunen 2008

\begin{tabular}{|c|c|}
\hline Methods & $\begin{array}{l}\text { Country: USA } \\
\text { Randomisation: Method not stated }\end{array}$ \\
\hline Participants & 263 women, mean age 39, mean CPD 19, exercise $<3$ times a week \\
\hline Interventions & $\begin{array}{l}\text { (a) Intervention 1: CV equipment, individual, facility, } 40 \text { mins, } 60 \%-80 \% \text { HR max (twice a week for } 5 \\
\text { weeks, then once a week for } 14 \text { weeks) +CP (once a week for } 19 \text { weeks) + nicotine gum } \\
\text { (b) Intervention 2: CP and nicotine gum as (a) + health education for same number of sessions as for ex- } \\
\text { ercise in (a) } \\
\text { (c) Control: CP and nicotine gum as (a) }\end{array}$ \\
\hline
\end{tabular}

Outcomes

Prolonged abstinence

Validation: $\mathrm{CO}$, cotinine

Follow-up: 1 week, 1, 4, 12 months

\section{Notes}

Contact time balanced between (a) and (b). (b) used as control condition in forest plot (total of 221 women randomised to groups (a) and (b)). 2/34 quit in control (c)

Funding: Support was provided by NIH/NIDA-12503 grant to Taru Kinnunen and by grants from the Academy of Finland $(200075,103650)$ to Tellervo Korhonen

Conflict of interest: Information not provided

\section{Risk of bias}

\begin{tabular}{|c|c|c|}
\hline Bias & Authors' judgement & Support for judgement \\
\hline $\begin{array}{l}\text { Random sequence genera- } \\
\text { tion (selection bias) }\end{array}$ & Unclear risk & $\begin{array}{l}\text { Randomised at baseline visit, method not stated. Recruitment to condition (c) } \\
\text { discontinued during trial due to poor early outcomes. Availability of facilities } \\
\text { allowed for a greater number of participants to be randomised into the exer- } \\
\text { cise intervention than into the equal-contact condition }\end{array}$ \\
\hline $\begin{array}{l}\text { Allocation concealment } \\
\text { (selection bias) }\end{array}$ & Unclear risk & No details reported \\
\hline $\begin{array}{l}\text { Blinding of outcome as- } \\
\text { sessment (detection bias) } \\
\text { All outcomes }\end{array}$ & Low risk & $\begin{array}{l}\text { Details of blinding not specified, but as self-reports of smoking were validated } \\
\text { objectively by expired CO risk is considered as low }\end{array}$ \\
\hline $\begin{array}{l}\text { Incomplete outcome data } \\
\text { (attrition bias) } \\
\text { All outcomes }\end{array}$ & High risk & $\begin{array}{l}\text { Total of only } 25 \text { participants followed up in groups (a) and (b) } \\
\text { Not an ITT analysis, as } 263 \text { women were randomised in groups (a) and (b), but } \\
\text { only those considered to have made a quit attempt (92/125 in (a), 56/96 in (b), } \\
34 / 42 \text { in (c)) were included in the analysis }\end{array}$ \\
\hline
\end{tabular}


Kinnunen 2008 (Continued)

Selective reporting (re- Low risk Smoking outcomes reported as stated in Methods porting bias)

Maddison 2014

\begin{tabular}{|c|c|}
\hline Methods & $\begin{array}{l}\text { Country: New Zealand } \\
\text { Randomisation: Computer-generated }\end{array}$ \\
\hline Participants & 906 participants, $54 \%$ female, mean age 38 , mean CPD 20 , FTCD score $7,<150$ mins of MVPA per week. \\
\hline Interventions & $\begin{array}{l}\text { (a) Intervention: PA counselling, } 1 \text { face-to-face and } 9 \text { telephoned-based sessions over } 6 \text { months) + tele- } \\
\text { phoned-based CP for } 3 \text { months, with } 8 \text { weeks of subsidised nicotine replacement therapy (patches, } \\
\text { gum, or lozenge) } \\
\text { (b) Control: CP only as (a) }\end{array}$ \\
\hline & Exercise began after quit date \\
\hline
\end{tabular}

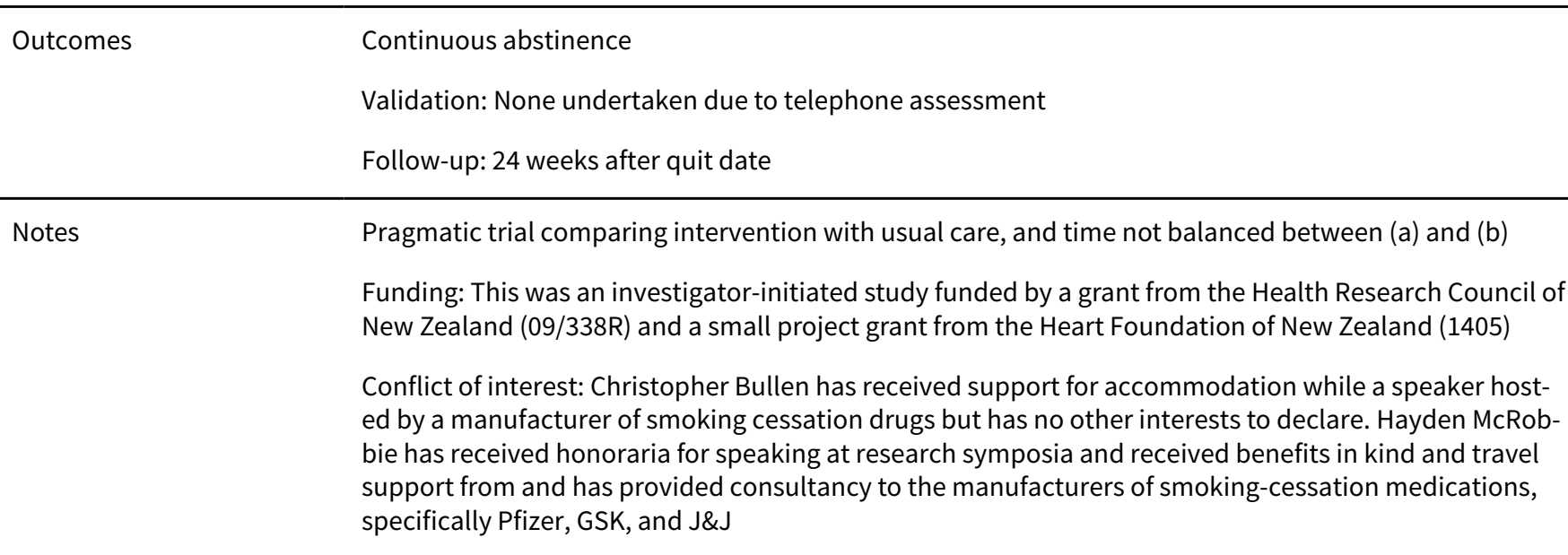

\section{Risk of bias}

\begin{tabular}{|c|c|c|}
\hline Bias & Authors' judgement & Support for judgement \\
\hline $\begin{array}{l}\text { Random sequence genera- } \\
\text { tion (selection bias) }\end{array}$ & Low risk & Computer-generated \\
\hline \multirow[t]{2}{*}{$\begin{array}{l}\text { Allocation concealment } \\
\text { (selection bias) }\end{array}$} & Low risk & $\begin{array}{l}\text { Concealment of allocation was ensured by means of a central computerised } \\
\text { service up to the point of randomisation. }\end{array}$ \\
\hline & & $\begin{array}{l}\text { Study researchers conducting assessments were not blinded to treatment allo- } \\
\text { cation }\end{array}$ \\
\hline $\begin{array}{l}\text { Blinding of outcome as- } \\
\text { sessment (detection bias) } \\
\text { All outcomes }\end{array}$ & High risk & $\begin{array}{l}\text { Study researchers conducting these assessments were not blinded to treat- } \\
\text { ment allocation and primary outcome of self-reported smoking status was not } \\
\text { validated objectively }\end{array}$ \\
\hline $\begin{array}{l}\text { Incomplete outcome data } \\
\text { (attrition bias) }\end{array}$ & Low risk & ITT analysis \\
\hline All outcomes & & Follow-up rate lower in intervention group (89\%) than in control group (96\%) \\
\hline
\end{tabular}


Maddison 2014 (Continued)

Selective reporting (re- Low risk Smoking outcomes reported as stated in Methods porting bias)

Marcus 1991

\begin{tabular}{ll}
\hline Methods & $\begin{array}{l}\text { Country: USA } \\
\text { Randomisation: Method not stated }\end{array}$ \\
\hline Participants & 20 women, mean age 39, mean CPD 28, exercise < once a week \\
\hline Interventions & $\begin{array}{l}\text { (a) CV equipment: group, facility } 30-45 \text { mins, 70\% - 85\% HR max, } 3 \text { times/week for } 15 \text { weeks + CP (twice } \\
\text { a week for 4 weeks) } \\
\text { (b) CP only (twice a week for } 4 \text { weeks) } \\
\text { Exercise began before quit date }\end{array}$ \\
\hline Outcomes & $\begin{array}{l}\text { 7-day PPA } \\
\text { Validation: saliva cotinine }<10 \mathrm{ng} / \mathrm{ml}\end{array}$ \\
Follow-up: $1,3,12$ months \\
\hline Contact time not balanced \\
Funding: not reported \\
Conflcts of interest: Not reported
\end{tabular}

\section{Risk of bias}

\begin{tabular}{|c|c|c|}
\hline Bias & Authors' judgement & Support for judgement \\
\hline $\begin{array}{l}\text { Random sequence genera- } \\
\text { tion (selection bias) }\end{array}$ & Unclear risk & Method not stated \\
\hline $\begin{array}{l}\text { Allocation concealment } \\
\text { (selection bias) }\end{array}$ & Unclear risk & Not stated \\
\hline $\begin{array}{l}\text { Blinding of outcome as- } \\
\text { sessment (detection bias) } \\
\text { All outcomes }\end{array}$ & Low risk & $\begin{array}{l}\text { Blinding of smoking assessments not stated, but as self-reports of smoking } \\
\text { were validated objectively by expired } \mathrm{CO} \text { and saliva cotinine risk is considered } \\
\text { as low }\end{array}$ \\
\hline $\begin{array}{l}\text { Incomplete outcome data } \\
\text { (attrition bias) } \\
\text { All outcomes }\end{array}$ & Low risk & 1 participant did not attend follow-ups and was counted as a smoker \\
\hline $\begin{array}{l}\text { Selective reporting (re- } \\
\text { porting bias) }\end{array}$ & Low risk & All smoking outcomes were reported as stated in Methods \\
\hline
\end{tabular}

Marcus 1995

$\begin{array}{ll}\text { Methods } & \text { Country: USA } \\ & \text { Randomisation: Method not stated }\end{array}$

Participants 20 women, mean age 38, mean CPD 23, exercise < once a week 
Marcus 1995 (Continued)

Interventions (a) CV equipment: group, facility, 30 - 40 mins, 60\% - 85\% HR reserve, (3 times/week for 15 weeks) + CP

(once a week for 12 weeks)

(b) CP as (a) + health education 3 times/week for 15 weeks

Exercise began before quit date

\begin{tabular}{ll}
\hline Outcomes & $\begin{array}{l}\text { 7-day PPA } \\
\text { Validation: saliva cotinine }<10 \mathrm{ng} / \mathrm{ml} \\
\text { Follow-up: } 1,3,12 \text { months }\end{array}$ \\
\hline Notes & Contact time balanced between (a) and (b) \\
& Funding: not reported \\
& Conflcts of interest: Not reported
\end{tabular}

\section{Risk of bias}

\begin{tabular}{lll}
\hline Bias & Authors' judgement & Support for judgement \\
\hline $\begin{array}{l}\text { Random sequence genera- } \\
\text { tion (selection bias) }\end{array}$ & Unclear risk & Not stated \\
\hline $\begin{array}{l}\text { Allocation concealment } \\
\text { (selection bias) }\end{array}$ & Unclear risk & Not stated \\
\hline $\begin{array}{l}\text { Blinding of outcome as- } \\
\text { sessment (detection bias) } \\
\text { All outcomes }\end{array}$ & Low risk & $\begin{array}{l}\text { Blinding of smoking assessments not stated, but as self-reports of smoking } \\
\text { were validated objectively by expired CO and saliva cotinine risk is considered } \\
\text { as low }\end{array}$ \\
\hline $\begin{array}{l}\text { Incomplete outcome data } \\
\text { (attrition bias) } \\
\begin{array}{l}\text { All outcomes } \\
\text { Selective reporting (re- }\end{array}\end{array}$ & Low risk & $\begin{array}{l}\text { All participants were followed up and included in the analysis for the primary } \\
\text { outcome }\end{array}$ \\
\hline \begin{tabular}{l} 
porting bias) \\
\hline
\end{tabular} & & Smoking outcomes reported as described in Methods \\
\hline
\end{tabular}

\section{Marcus 1999}

\begin{tabular}{ll}
\hline Methods & $\begin{array}{l}\text { Country: USA } \\
\text { Randomisation: Computer-generated }\end{array}$ \\
\hline Participants & 281 women, mean age 40, mean CPD 22, exercise < twice a week \\
\hline Interventions & $\begin{array}{l}\text { (a) Intervention: CV equipment: group, facility, } 30 \text { - } 40 \text { mins, } 60 \%-85 \% \text { HR reserve, (3 times/week for } 12 \\
\text { weeks) }+ \text { CP (once a week for } 12 \text { weeks) } \\
\text { (b) Control: CP as (a) once/week for } 12 \text { weeks + health education } 3 \text { times/week for } 12 \text { weeks } \\
\text { Exercise began before quit date }\end{array}$ \\
\hline Outcomes & $\begin{array}{l}\text { Validation: saliva cotinine }<10 \text { ng/ml, CO < } 8 \text { ppm. } \\
\text { Follow-up: } 3,12 \text { months }\end{array}$ \\
\hline Notes & $\begin{array}{l}\text { Contact time balanced between (a) and (b) } \\
\text { Funding: This project was supported in part through grants K07CA01757 and R29CA59660 from the Na- } \\
\text { tional Cancer Institute, Bethesda, Md, and an R29CA59660 supplementary grant from the Office of Re- } \\
\text { search on Women's Health,National Institutes of Health, Bethesda, Md (Dr Marcus). }\end{array}$ \\
\hline
\end{tabular}


Marcus 1999 (Continued)

Conflcts of interest: Not reported

\section{Risk of bias}

\begin{tabular}{|c|c|c|}
\hline Bias & Authors' judgement & Support for judgement \\
\hline $\begin{array}{l}\text { Random sequence genera- } \\
\text { tion (selection bias) }\end{array}$ & Low risk & $\begin{array}{l}\text { Quote: "The randomisation code for group assignment was generated by a } \\
\text { computer program" }\end{array}$ \\
\hline $\begin{array}{l}\text { Allocation concealment } \\
\text { (selection bias) }\end{array}$ & Unclear risk & Not stated \\
\hline $\begin{array}{l}\text { Blinding of outcome as- } \\
\text { sessment (detection bias) } \\
\text { All outcomes }\end{array}$ & Unclear risk & $\begin{array}{l}\text { Blinding of smoking assessments not stated, but as self-reports of smoking } \\
\text { were validated objectively by expired CO and saliva cotinine risk is considered } \\
\text { as low }\end{array}$ \\
\hline $\begin{array}{l}\text { Incomplete outcome data } \\
\text { (attrition bias) } \\
\text { All outcomes }\end{array}$ & Low risk & $44 \%$ of (a) and $50 \%$ of (b) lost at 12 months, included as smokers \\
\hline $\begin{array}{l}\text { Selective reporting (re- } \\
\text { porting bias) }\end{array}$ & Low risk & Smoking outcomes reported as described in Methods \\
\hline Other bias & Low risk & $\begin{array}{l}\text { The average weight at baseline was significantly higher in the exercise group } \\
\text { than in the control group. Research suggests that women who weigh more are } \\
\text { more concerned about their weight and thus may be less motivated to quit } \\
\text { smoking }\end{array}$ \\
\hline
\end{tabular}

Marcus 2005

\begin{tabular}{ll} 
Methods & $\begin{array}{l}\text { Country: USA } \\
\text { Randomisation: Computer-generated }\end{array}$ \\
\hline Participants & 217 women, mean age 43, mean CPD 21; exercise $\leq 90$ mins/wk \\
\hline Interventions & $\begin{array}{l}\text { (a) Intervention: CV various: group/individual, home/facility, } 45 \text { mins, } 45 \%-59 \% \text { HR reserve, (facili- } \\
\text { ty: once/week for } 8 \text { weeks, goal: } 165 \text { mins/week) + CP (once a week for } 8 \text { weeks), with offer of nicotine } \\
\text { patch } \\
\text { (b) Control: CP as (a) once/week for } 8 \text { weeks + health education once/week for } 8 \text { weeks } \\
\text { Exercise began before quit date }\end{array}$
\end{tabular}

\begin{tabular}{ll}
\hline Outcomes & Continuous abstinence \\
& Validation: saliva cotinine $<10 \mathrm{ng} / \mathrm{ml}, \mathrm{CO}<8 \mathrm{ppm}$. \\
& Follow-up: 3,12 months
\end{tabular}

Notes Contact time balanced between (a) and (b)

Funding: This project was supported in part through grants from the National Cancer Institute (CA77249) and the National Heart, Lung, and Blood Institute (HL64342, HL68422)

Conflcts of interest: Not reported

\section{Risk of bias}

\section{Bias}

Authors' judgement Support for judgement 
Marcus 2005 (Continued)

Random sequence genera- Low risk Quote: "Group assignment was based on a randomisation code generated by tion (selection bias) a computer software program and was stratified based on participant's patch usage decision"

\begin{tabular}{|c|c|c|}
\hline $\begin{array}{l}\text { Allocation concealment } \\
\text { (selection bias) }\end{array}$ & Unclear risk & Not stated \\
\hline $\begin{array}{l}\text { Blinding of outcome as- } \\
\text { sessment (detection bias) } \\
\text { All outcomes }\end{array}$ & Low risk & $\begin{array}{l}\text { Blinding of smoking assessments not stated, but as self-reports of smoking } \\
\text { were validated objectively by expired CO and saliva cotinine risk is considered } \\
\text { as low }\end{array}$ \\
\hline $\begin{array}{l}\text { Incomplete outcome data } \\
\text { (attrition bias) } \\
\text { All outcomes }\end{array}$ & High risk & $\begin{array}{l}\text { ITT analysis, } 75 \% \text { (a) and } 68 \% \text { (b) did not attend 12-month follow-up session, } \\
\text { counted as smokers }\end{array}$ \\
\hline $\begin{array}{l}\text { Selective reporting (re- } \\
\text { porting bias) }\end{array}$ & Low risk & $\begin{array}{l}\text { 1- and 6-month follow-up data for smoking behavioural outcomes (in proto- } \\
\text { col) are not reported, but the end of treatment, 3- and 12-months' are reported }\end{array}$ \\
\hline
\end{tabular}

Martin 1997

\begin{tabular}{|c|c|}
\hline Methods & $\begin{array}{l}\text { Country: USA } \\
\text { Randomisation: method not stated }\end{array}$ \\
\hline Participants & 92 women, 113 men, problem drinkers, mean age 42, mean CPD 27 , exercise < once a week \\
\hline Interventions & $\begin{array}{l}\text { (a) Intervention 1: CV activity: various, group/individual, facility/home, } 15 \text { - } 45 \text { mins, } 60 \%-75 \% \text { HR max, } \\
\text { (once/week for } 4 \text { weeks) + CP: (once/week for } 12 \text { weeks) } \\
\text { (b) Intervention 2: CP as (a) + nicotine gum (does not contribute to this review) } \\
\text { (c) Control: Different CP (once/week for } 8 \text { weeks) and Nicotine Anonymous meetings ( } 3 \text { times/week for } \\
4 \text { weeks) } \\
\text { Exercise began on quit date }\end{array}$ \\
\hline Outcomes & $\begin{array}{l}\text { 7-day PPA } \\
\text { Validation: } \mathrm{CO}<10 \mathrm{ppm} \\
\text { Follow-up: } 7 \text { days, } 6,12 \text { months }\end{array}$ \\
\hline Notes & $\begin{array}{l}\text { Contact time not matched, different cessation programmes } \\
\text { Funding: not reported }\end{array}$ \\
\hline & Conflict of interest: not reported \\
\hline
\end{tabular}

\section{Risk of bias}

\begin{tabular}{lll}
\hline Bias & Authors' judgement & Support for judgement \\
\hline $\begin{array}{l}\text { Random sequence genera- } \\
\text { tion (selection bias) }\end{array}$ & Unclear risk & Randomised, method not stated \\
\hline $\begin{array}{l}\text { Allocation concealment } \\
\text { (selection bias) }\end{array}$ & Unclear risk & No details reported \\
\hline $\begin{array}{l}\text { Blinding of outcome as- } \\
\text { sessment (detection bias) } \\
\text { All outcomes }\end{array}$ & Low risk & $\begin{array}{l}\text { Details of blinding not specified, but as self-reports of smoking were validated } \\
\text { objectively by expired CO risk is considered as low }\end{array}$ \\
\hline
\end{tabular}


Martin 1997 (Continued)

Incomplete outcome data Unclear risk Numbers lost to follow-up not reported, but all participants included in de(attrition bias) nominators

All outcomes

Selective reporting (re- Low risk Smoking outcomes reported as stated in Methods. porting bias)

\begin{tabular}{ll} 
McKay 2008 & \\
\hline Methods & $\begin{array}{l}\text { Country: USA } \\
\text { Randomisation: Computer-generated online }\end{array}$ \\
\hline
\end{tabular}

Participants $2318,78 \% \geq 30$ years of age, $83 \%>10$ CPD

(a) Web-based, multi-step programme designed to encourage physical activity with a motivational
component (e.g. exploring benefits and barriers) and a behavioural action plan (e.g. weekly schedules),
plus access to a peer support forum
(b) Web-based, multi-step programme introducing users to the key concepts and strategies of a behav-
ioural quit-smoking programme, including a peer support forum and 'ask the expert' tool
Did not state when exercise began relative to the quit date

\begin{tabular}{ll}
\hline Outcomes & 7-day PPA \\
& Validation: No biochemical validation as outcomes reported online or by telephone \\
& Follow-up: 3, 6 months
\end{tabular}

Notes Exercise condition (a) intended to be an attention placebo control condition

Funding: This research was supported by grant R01-CA79946 from the National Cancer Institute

Conflict of interest: None declared

\section{Risk of bias}

\begin{tabular}{lll}
\hline Bias & Authors' judgement & Support for judgement \\
\hline $\begin{array}{l}\text { Random sequence genera- } \\
\text { tion (selection bias) }\end{array}$ & Low risk & Randomly generated by a computer through the Internet \\
\hline $\begin{array}{l}\text { Allocation concealment } \\
\text { (selection bias) }\end{array}$ & Unclear risk & No detail given \\
\hline $\begin{array}{l}\text { Blinding of outcome as- } \\
\text { sessment (detection bias) } \\
\text { All outcomes }\end{array}$ & High risk & $\begin{array}{l}\text { Not stated if researchers conducting assessments (by telephone) were aware } \\
\text { of treatment allocation and self-reports of smoking status were not validated } \\
\text { objectively }\end{array}$ \\
\hline $\begin{array}{l}\text { Incomplete outcome data } \\
\text { (attrition bias) } \\
\text { All outcomes }\end{array}$ & High risk & $\begin{array}{l}\text { 60.2\% Int and 61.3\% Cont lost to follow-up at 6 months, counted as smokers in } \\
\text { analysis }\end{array}$ \\
\hline $\begin{array}{l}\text { Selective reporting (re- } \\
\text { porting bias) }\end{array}$ & Low risk & Smoking outcomes reported as stated in Methods \\
\hline
\end{tabular}


Patten 2017

\begin{tabular}{ll}
\hline Methods & Country: USA \\
& Randomisation: Method not stated \\
\hline Participants & 30 women, mean age $38,90 \%$ white ethnicity, smoking $\geq 10$ CPD for at least the past year, FTCD score \\
& $\begin{array}{l}\text { v.5, not currently achieving moderate-intensity exercise for at least } 30 \text { mins on at least } 5 \text { days/week or } \\
\text { vigorous exercise for at least } 20 \text { mins on at least } 3 \text { days/week, currently moderate-severe depressed de- } \\
\text { fined by a clinical cut-off score of }>16 \text { on } 10 \text {-item Center for Epidemiological Studies Depression Scale, } \\
37 \%(11 / 30) \text { had a current psychiatric diagnosis }\end{array}$
\end{tabular}

Interventions

(a) Exercise intervention: 30 - 40 mins supervised moderate-vigorous intensity exercise, thrice weekly for 12 weeks (gradual progression from moderate to vigorous exercise across weeks, individually-based at facility, various CV exercise equipment) + CP (15- 20 mins, once a week for 12 weeks, including 8 weeks nicotine patches)

(b) Control: health education (individually-based, 30 - 40 mins thrice weekly for 12 weeks) + CP (as for (a))

Exercise and $\mathrm{CP}$ began before quit date. The target quit date was the first session of week 3

$\begin{array}{ll}\text { Outcomes } & \text { 7-day PPA } \\ \text { Validation: saliva cotinine }<10 \mathrm{ng} / \mathrm{ml} \\ \text { Follow-up: end of treatment, and } 6 \text { months after quit date }\end{array}$

Notes

Control group balanced with exercise group for contact time. To save time, the exercise counselling was delivered while the participant was exercising. Limitations: no record of exercise outside of supervised exercise, over half of participants were taking antidepressant medication limiting the potential of the exercise intervention to aid cessation. Overly conservative cut-off for the depression scale (Center for Epidemiological Studies Depression Scale-10)?

Funding: Study was supported by CTSA grant number UL1 TR000135 from the National Center for Advancing Translational Sciences (NCATS), a component of the National Institutes of Health (NIH). Its contents are solely the responsibility of the authors and do not necessarily represent the official view of NIH. Funding for this study was also provided by a Mayo Clinic NIH-relief award, and a small grant award from the Department of Psychiatry and Psychology

Declared COIs: None declared

\section{Risk of bias}

\begin{tabular}{lll}
\hline Bias & Authors' judgement & Support for judgement \\
\hline $\begin{array}{l}\text { Random sequence genera- } \\
\text { tion (selection bias) }\end{array}$ & Unclear risk & Not reported \\
\hline $\begin{array}{l}\text { Allocation concealment } \\
\text { (selection bias) }\end{array}$ & Low risk & $\begin{array}{l}\text { Allocation to treatment conditions was unknown to the study staff or investi- } \\
\text { gators prior to assignments }\end{array}$ \\
\hline $\begin{array}{l}\text { Blinding of outcome as- } \\
\text { sessment (detection bias) } \\
\text { All outcomes }\end{array}$ & Low risk & $\begin{array}{l}\text { Study co-ordinator blinded to allocation group conducted all follow-ups; bio- } \\
\text { chemical validation used }\end{array}$ \\
\hline $\begin{array}{l}\text { Incomplete outcome data } \\
\text { (attrition bias) } \\
\text { All outcomes }\end{array}$ & Low risk & $\begin{array}{l}87 \% \text { were followed up at } 6 \text { months (same rate in 2 groups). Using an ITT ap- } \\
\text { proach, missing data were classified as smoking }\end{array}$ \\
\hline $\begin{array}{l}\text { Selective reporting (re- } \\
\text { porting bias) }\end{array}$ & Low risk & All outcomes stated in Methods were reported \\
\hline \hline
\end{tabular}


Prapavessis 2007

\begin{tabular}{ll} 
Methods & $\begin{array}{l}\text { Country: New Zealand } \\
\text { Randomisation: Computer-generated }\end{array}$ \\
\hline Participants & $\begin{array}{l}142 \text { women, mean age 38, exercise < twice a week. (following preliminary programme, } 21 \text { pretreatment } \\
\text { dropouts) }\end{array}$ \\
\hline Interventions & Phase 1 (6 weeks): 142 randomised supervised exercise programme or a supervised cognitive behav- \\
& Phase 2 (12 weeks): 121 who made a quit attempt re-randomised to 1 of 4 conditions: \\
(a) Intervention 1: CV activity: various, group/facility, 45 mins, $60 \%$ - $75 \%$ HR reserve, (3 times/week for \\
12 weeks) + CP (3 times/week for 12 weeks) \\
(b) Intervention 2: exercise as (a) plus nicotine patches \\
(c) Intervention 3: Cognitive behavioural cessation programme 3 times/week for 12 weeks \\
(d) Intervention 4: as (c) plus nicotine patches \\
Exercise began before quit date
\end{tabular}

\begin{tabular}{ll}
\hline Outcomes & Continuous abstinence \\
& Validation: saliva cotinine $<10 \mathrm{ng} / \mathrm{ml}, \mathrm{CO}<10 \mathrm{ppm}$ \\
& Follow-up: 6 weeks, 3,12 months
\end{tabular}

Notes Contact time balanced between $\mathrm{a}, \mathrm{b}, \mathrm{c}$ and $\mathrm{d}$

Funding: National Heart Foundation of New Zealand funded this project (Project \# 905) and GlaxoSmithKlein (GSK) provided the transdermal nicotine patches for the study

Conflict of interest: Not reported

\section{Risk of bias}

\begin{tabular}{lll}
\hline Bias & Authors' judgement & Support for judgement \\
\hline $\begin{array}{l}\text { Random sequence genera- } \\
\text { tion (selection bias) }\end{array}$ & Low risk & Computer-generated randomisation. \\
\hline $\begin{array}{l}\text { Allocation concealment } \\
\text { (selection bias) }\end{array}$ & Unclear risk & Not stated \\
\hline $\begin{array}{l}\text { Blinding of outcome as- } \\
\text { sessment (detection bias) } \\
\text { All outcomes }\end{array}$ & Low risk & $\begin{array}{l}\text { Details of blinding not specified, but as self-reports of smoking were validated } \\
\text { objectively by expired CO and saliva cotinine, risk is considered as low }\end{array}$ \\
\hline $\begin{array}{l}\text { Incomplete outcome data } \\
\text { (attrition bias) } \\
\text { All outcomes }\end{array}$ & High risk & $\begin{array}{l}21 \text { pretreatment dropouts excluded from analysis. Loss to follow-up higher in } \\
\text { (a)+(b), 40\%, than in (c) +(d), 23\% (P = 0.05). Not stated whether those lost to } \\
\text { follow-up were counted as smokers }\end{array}$ \\
\hline $\begin{array}{l}\text { Selective reporting (re- } \\
\text { porting bias) }\end{array}$ & Low risk & \begin{tabular}{l} 
Smoking outcomes reported as stated in Methods \\
\hline
\end{tabular} \\
\hline
\end{tabular}

Prapavessis 2016

\begin{tabular}{ll}
\hline Methods & Country: Canada \\
& Randomisation: Computer-generated
\end{tabular}

Exercise interventions for smoking cessation (Review)

Copyright $\odot 2019$ The Cochrane Collaboration. Published by John Wiley \& Sons, Ltd. 
Prapavessis 2016 (Continued)

Participants

413 women, average age 42.31, 16.76 CPD at baseline, FTCD score 5.4, engaged in $\leq 2 \times 30$-min bouts of moderate or vigorous physical activity a week over the past 6 months

Interventions

All participants completed a 14-week structured exercise programme with NRT. Supervised group exercise; 3 sessions/wk (45 mins duration) for 8 weeks, 2 sessions weeks 9 - 11 and 1 session during weeks 12 - 14. Workload progressively increased to $70 \%-75 \%$ maximum HR over the 14 weeks. NRT started after 4 weeks of exercising. Then randomised to 1 of 4 conditions (a) exercise maintenance + smoking cessation maintenance, b) exercise maintenance + contact control, (c) smoking cessation maintenance + contact control, or (d) contact control

(a) and (c): Received Forever Free booklets at end of 14 weeks

(a) and (b): $5 \times 25$-min weekly CBT sessions in a group format teaching self-regulatory skills for exercise maintenance. After 14 weeks, received $7 \times 15$-min bi-weekly (for the first month, monthly (for next 2 months) and then bi-monthly (for last 8 months) telephone counselling sessions

(c) and (d): Messages reinforcing women's health issues were communicated. After week 14, messages reinforcing the Forever Free booklets (c) and/or women's health issues (d) were communicated.

Exercise began 4 weeks before quit date; NRT began on quit date; relapse prevention support began following randomisation and after 14-week exercise programme

$\begin{array}{ll}\text { Outcomes } & \begin{array}{l}\text { Continuous abstinence } \\ \text { Validation: } \mathrm{CO}<6 \mathrm{ppm}\end{array} \\ \text { Follow-up: end of treatment, 26, 56 weeks }\end{array}$

Notes
Relapse prevention intervention with randomisation after 14 weeks. Change in physical activity or fitness not reported between baseline and week 14 (end of supervised exercise). High loss to end-of-intervention assessments of smoking status. The trial did not have sufficient power to detect a significant difference in cessation rates at 14 and 26 weeks. Smoking status consistently related to adherence across trial. Staying involved with the exercise, NRT and maintenance components of the intervention was associated with improved cessation rates.

Funding: This was an investigator-initiated study funded by a grant from the Canadian Cancer Society (\#019876-PI-HP). The Exercise and Health Psychology Lab (www.ehpl.uwo.ca) where this work was conducted is supported by a Canadian Foundation Innovationinfrastructure grant (\#312466) award to the $\mathrm{PI}-\mathrm{HP}$

Conflct of interest: None declared

\section{Risk of bias}

\begin{tabular}{lll}
\hline Bias & Authors' judgement & Support for judgement \\
\hline $\begin{array}{l}\text { Random sequence genera- } \\
\text { tion (selection bias) }\end{array}$ & Low risk & Computer-generated \\
\hline $\begin{array}{l}\text { Allocation concealment } \\
\text { (selection bias) }\end{array}$ & Low risk & $\begin{array}{l}\text { The project manager used numbered containers to implement the random al- } \\
\text { location sequence, and the sequence was concealed until interventions were } \\
\text { assigned }\end{array}$ \\
\hline $\begin{array}{l}\text { Blinding of outcome as- } \\
\text { sessment (detection bias) } \\
\text { All outcomes }\end{array}$ & Low risk & $\begin{array}{l}\text { Research assistants not blinded to treatment allocation, but low risk of bias as } \\
\text { self-reports of smoking abstinence were validated with expired CO }\end{array}$ \\
\hline $\begin{array}{l}\text { Incomplete outcome data } \\
\text { (attrition bias) } \\
\text { All outcomes }\end{array}$ & High risk & $\begin{array}{l}\text { ITT reported with participants not reporting end-point data treated as smok- } \\
\text { ers. High risk as only 46\% (189/413) completed follow-up at 12 months post- } \\
\text { treatment }\end{array}$ \\
\hline
\end{tabular}


Prapavessis 2016 (Continued)

Selective reporting (re- Low risk Outcomes fully reported as stated in protocol porting bias)

Russell 1988

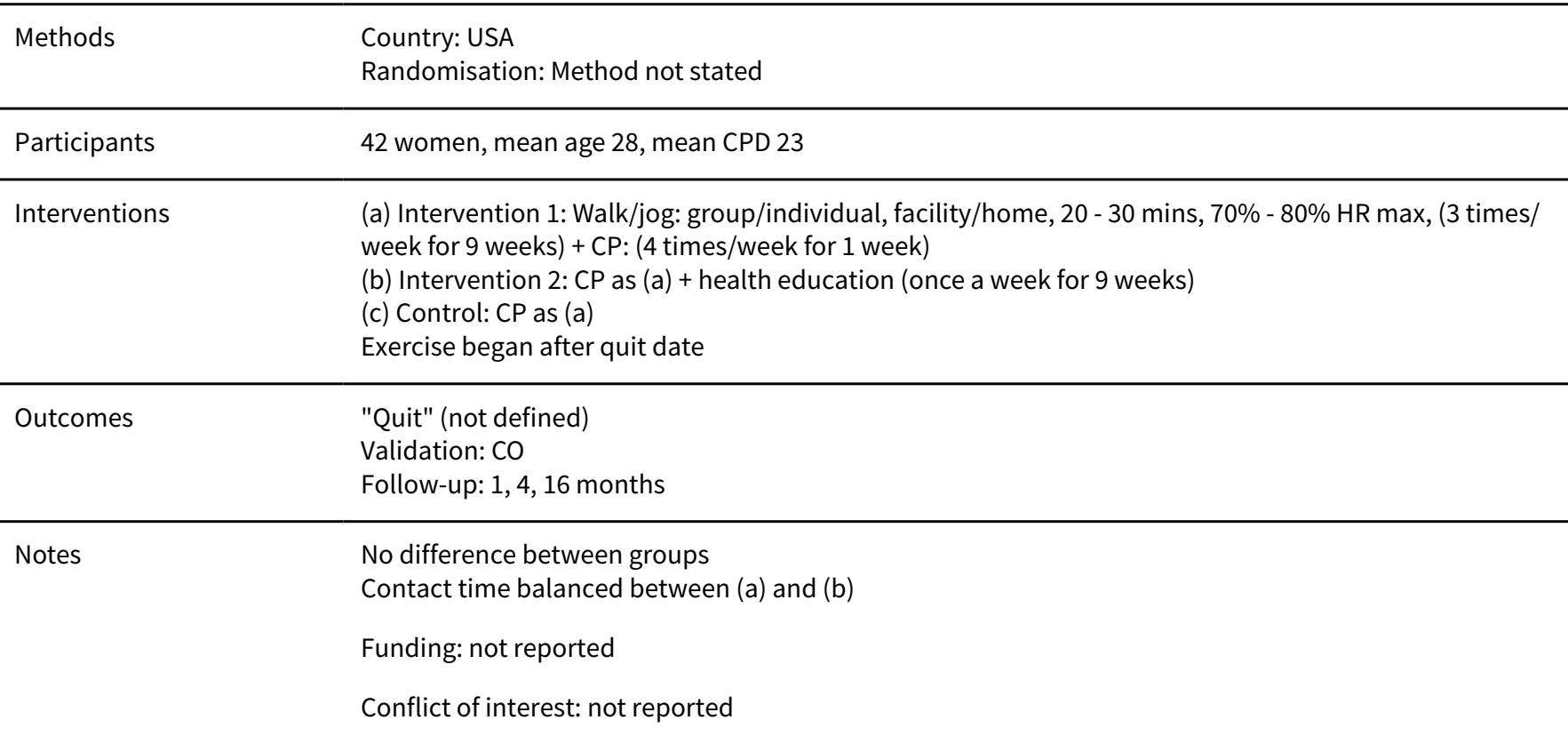

\section{Risk of bias}

\begin{tabular}{lll}
\hline Bias & Authors' judgement & Support for judgement \\
\hline $\begin{array}{l}\text { Random sequence genera- } \\
\text { tion (selection bias) }\end{array}$ & Unclear risk & Not stated \\
\hline $\begin{array}{l}\text { Allocation concealment } \\
\text { (selection bias) }\end{array}$ & Unclear risk & Not stated \\
\hline $\begin{array}{l}\text { Blinding of outcome as- } \\
\text { sessment (detection bias) }\end{array}$ & Low risk & $\begin{array}{l}\text { Details of blinding not stated, but as self-reports of smoking were validated } \\
\text { objectively by expired CO risk is considered low }\end{array}$ \\
\hline $\begin{array}{l}\text { Incomplete outcome data } \\
\text { (attrition bias) } \\
\text { All outcomes }\end{array}$ & Unclear risk & \begin{tabular}{l} 
Not stated \\
\hline $\begin{array}{l}\text { Selective reporting (re- } \\
\text { porting bias) }\end{array}$
\end{tabular} \\
\hline
\end{tabular}

Smits 2016

$\begin{array}{ll}\text { Methods } & \text { Country: USA } \\ \text { Randomisation: generated by study statistician and placed in sealed envelopes }\end{array}$


Smits 2016 (Continued)

Participants

136 participants, $52 \%$ female, $74 \%$ white ethnicity, mean age 44, at least 1 year of smoking at least 10 CPD, mean CPD 17, mean FTND score 5.4, sedentary (moderate-intensity exercise $<$ twice a week for 30 mins or less), elevated anxiety sensitivity (prescreen score of $\geq 20$ on the 16-item Anxiety Sensitivity Inventory; ASI-16) (a) Exercise intervention: 35 mins of supervised moderate-vigorous intensity exercise (at $77 \%$ - $85 \%$ max HR by week 4), thrice-weekly for 15 weeks (individually-based at facility using treadmills) + CP (60 mins CBT weekly for 7 weeks, optional nicotine patches for up to 8 weeks)

(b) Control: wellness education (individually-based, 30 - 40 mins thrice-weekly for 15 weeks) + CP as for (a)

Exercise and CP began before quit date, target quit date in week 6

\section{Risk of bias}

\begin{tabular}{lll}
\hline Bias & Authors' judgement & Support for judgement \\
\hline $\begin{array}{l}\text { Random sequence genera- } \\
\text { tion (selection bias) }\end{array}$ & Low risk & $\begin{array}{l}\text { Randomisation was generated by the study statistician and placed in sealed } \\
\text { envelopes }\end{array}$ \\
\hline $\begin{array}{l}\text { Allocation concealment } \\
\text { (selection bias) }\end{array}$ & Low risk & $\begin{array}{l}\text { At treatment inception, the therapist opened the envelope corresponding to } \\
\text { the cohort number. Allocation unknown before assignment }\end{array}$ \\
\hline $\begin{array}{l}\text { Blinding of outcome as- } \\
\text { sessment (detection bias) }\end{array}$ & Low risk & $\begin{array}{l}\text { An assessment team blind to study condition conducted exercise assessments } \\
\text { (from protocol). Blinding of smoking assessments not stated but this is not a } \\
\text { high risk as the primary outcome included objective assessment of smoking } \\
\text { status }\end{array}$ \\
\hline $\begin{array}{l}\text { Incomplete outcome data } \\
\text { (attrition bias) } \\
\text { All outcomes }\end{array}$ & High risk & $\begin{array}{l}\text { Using an ITT approach, missing data were classified as missing rather than } \\
\text { computing missing data or counting those missing as smokers (generally rec- } \\
\text { ommended approach). Only 49\% were followed up at } 6 \text { months }\end{array}$ \\
\hline $\begin{array}{l}\text { Selective reporting (re- } \\
\text { porting bias) }\end{array}$ & Low risk & \begin{tabular}{l} 
Outcomes stated in Methods were reported \\
\hline
\end{tabular}
\end{tabular}

Taylor 1988

Methods Country: USA


Taylor 1988 (Continued)

Randomisation: Method not stated

\begin{tabular}{ll}
\hline Participants & 68 men, post-acute myocardial infarction \\
\hline Interventions & $\begin{array}{l}\text { (a) Intervention 1: CV activity: various, group, facility, } 30-40 \text { mins, } 70 \%-85 \% \text { HR max, (i) }(3,23) \text { (ii) }(3,8) \\
+ \text { CP } 1 \text { session; } \\
\text { (b) Intervention 2: (i, ii) as (a) home: } 20 \text { mins, } \times 5 / \text { wk } \\
\text { (c) Control: Fitness test at end of treatment only } \\
\text { (d) Intervention 3: Fitness test at baseline and end of treatment, cessation programme as (a) }\end{array}$ \\
\hline Outcomes & Validation: plasma thiocyanate \\
\hline Notes & Collow-up: 23 weeks \\
Funding: not reported & Conflicts of interest: not reported
\end{tabular}

\section{Risk of bias}

\section{Bias}

Authors' judgement Support for judgement

\begin{tabular}{l}
$\begin{array}{l}\text { Random sequence genera- } \\
\text { tion (selection bias) }\end{array}$ \\
\hline
\end{tabular}

tion (selection bias)

\begin{tabular}{lll}
\hline $\begin{array}{l}\text { Allocation concealment } \\
\text { (selection bias) }\end{array}$ & Unclear risk & Not stated
\end{tabular}

\begin{tabular}{|c|c|c|}
\hline $\begin{array}{l}\text { Blinding of outcome as- } \\
\text { sessment (detection bias) }\end{array}$ & Unclear risk & $\begin{array}{l}\text { Details of blinding not stated. Self-reports of smoking were validated objec- } \\
\text { tively by plasma thiocyanate risk only in a sub-sample }\end{array}$ \\
\hline
\end{tabular}

All outcomes

\begin{tabular}{lll}
$\begin{array}{l}\text { Incomplete outcome data } \\
\text { (attrition bias) } \\
\text { All outcomes }\end{array}$ & Unclear risk & Not stated \\
\hline $\begin{array}{l}\text { Selective reporting (re- } \\
\text { porting bias) }\end{array}$ & Low risk & Smoking outcomes reported as described in Methods \\
\hline
\end{tabular}

\begin{tabular}{ll} 
Ussher 2003 & $\begin{array}{l}\text { Country: UK } \\
\text { Randomisation: Computer-generated }\end{array}$ \\
\hline Participants & $\begin{array}{l}188 \text { women, } 111 \text { men, mean age: } 43 \text {, mean CPD: } 22 ;<5 \text { days of } 30 \text { mins moderate-intensity exercise a } \\
\text { week }\end{array}$ \\
\hline Interventions & $\begin{array}{l}\text { (a) Intervention: Exercise counselling (once a week for } 7 \text { weeks) + CP (once a week for } 7 \text { weeks) } \\
\text { (b) Control: Cessation programme as (a) once/week for } 7 \text { weeks + brief health education once/week for } \\
7 \text { weeks } \\
\text { Exercise began before quit date }\end{array}$ \\
\hline Outcomes & $\begin{array}{l}\text { Continuous abstinence } \\
\text { Validation: CO }<10 \text { ppm } \\
\text { Follow-up: } 6 \text { weeks, } 12 \text { months }\end{array}$ \\
\hline
\end{tabular}


Ussher 2003 (Continued)

Notes Contact time balanced between $(a)$ and (b)

Funding: This study was supported through grant CE1198/0101from the Cancer Research Campaign (now Cancer Research UK) to the authors

Conflicts of interest: Not reported

\section{Risk of bias}

\begin{tabular}{|c|c|c|}
\hline Bias & Authors' judgement & Support for judgement \\
\hline $\begin{array}{l}\text { Random sequence genera- } \\
\text { tion (selection bias) }\end{array}$ & Low risk & Computer-generated \\
\hline $\begin{array}{l}\text { Allocation concealment } \\
\text { (selection bias) }\end{array}$ & High risk & Personnel used a list of random numbers \\
\hline $\begin{array}{l}\text { Blinding of outcome as- } \\
\text { sessment (detection bias) } \\
\text { All outcomes }\end{array}$ & Low risk & $\begin{array}{l}\text { Researchers conducting assessments were aware of treatment allocation. As } \\
\text { self-reports of smoking were validated objectively by expired CO, risk is con- } \\
\text { sidered low }\end{array}$ \\
\hline $\begin{array}{l}\text { Incomplete outcome data } \\
\text { (attrition bias) } \\
\text { All outcomes }\end{array}$ & Low risk & $\begin{array}{l}27 \text { participants could not be contacted at the } 12 \text {-month follow-up and were } \\
\text { counted as smokers, with similar follow-up for the } 2 \text { groups }\end{array}$ \\
\hline $\begin{array}{l}\text { Selective reporting (re- } \\
\text { porting bias) }\end{array}$ & Low risk & Smoking outcomes reported as described in Methods \\
\hline
\end{tabular}

\section{Ussher 2015}

$\begin{array}{ll}\text { Methods } & \text { Country: UK } \\ \text { Randomisation: Computer-generated }\end{array}$

$\begin{array}{ll}\text { Participants } & 789 \text { pregnant women, mean age } 28, \text { white ethnicity } 78 \% \text {, median CPD before pregnancy } 20 \text {, median } \\ \text { CPD at randomisation } 10 \text {, median FTCD score } 4,70 \% \text { self-report } \geq 150 \text { mins/week of moderate-vigorous } \\ \text { physical activity }\end{array}$
physical activity

Interventions (a) Exercise intervention: Up to 30 mins of supervised moderate-intensity exercise 14 sessions over 8
weeks, twice a week for 6 weeks, then weekly for 2 weeks + CP weekly for 6 weeks

(b) Control: $\mathrm{CP}$ as (a)

Exercise and CP began 1 week before quit date

\begin{tabular}{ll}
\hline Outcomes & Continuous abstinence \\
& Validation: saliva cotinine $<10 \mathrm{ng} / \mathrm{ml}$ or $\mathrm{CO}<8 \mathrm{ppm}$ or both \\
& Follow-up: to end of pregnancy (variable), and 6 months postpartum \\
\hline Notes & $\begin{array}{l}\text { Funding: This study was funded by the NIHR health technology assessment programme (grant } \\
07.01 .14) .\end{array}$ \\
Conflicts of interest: All authors have completed the ICMJE uniform disclosure form at www.icm- \\
je.org/coi_disclosure.pdf (available on request from the corresponding author) and declare: no support \\
from any organisation for the submitted work; in the past three years PA has done one day of consul- \\
tancy for Pfizer concerning general smoking cessation advice and not about particular products, and
\end{tabular}


Ussher 2015 (Continued)

RW has undertaken research and consultancy for companies (Pfizer and GlaxoSmithKline) that develop and manufacture smoking cessation drugs in the past three years; in the past three years TC has been paid for speaking at two educational events that were part or wholly sponsored by a company (Pierre Fabre Laboratories, France) that manufactures nicotine replacement therapy; RW is an unpaid trustee of the stop smoking charity QUIT and an unpaid director of the National Centre for Smoking Cessation and Training; no other relationships or activities that could appear to have influenced the submitted work

\section{Risk of bias}

\begin{tabular}{lll}
\hline Bias & Authors' judgement & Support for judgement \\
\hline $\begin{array}{l}\text { Random sequence genera- } \\
\text { tion (selection bias) }\end{array}$ & Low risk & Computer-generated \\
\hline $\begin{array}{l}\text { Allocation concealment } \\
\text { (selection bias) }\end{array}$ & Low risk & $\begin{array}{l}\text { Allocation to treatment conditions was unknown to the study staff or investi- } \\
\text { gators prior to assignments }\end{array}$ \\
\hline $\begin{array}{l}\text { Blinding of outcome as- } \\
\text { sessment (detection bias) }\end{array}$ & Low risk & $\begin{array}{l}\text { Researcher blinded to allocation group conducted all follow-ups, but not al- } \\
\text { ways possible. As the primary outcome, at end of pregnancy, was based on ob- } \\
\text { jective assessment using expired co or saliva cotinine or both, we considered } \\
\text { there was low risk of the results being altered }\end{array}$ \\
\hline $\begin{array}{l}\text { Incomplete outcome data } \\
\text { (attrition bias) } \\
\text { All outcomes }\end{array}$ & Low risk & $\begin{array}{l}\text { 89\% of those randomised were followed up at end of pregnancy and the fol- } \\
\text { low-up rate was similar for the 2 groups. Using an ITT approach, missing data } \\
\text { were classified as smoking }\end{array}$ \\
\hline $\begin{array}{l}\text { Selective reporting (re- } \\
\text { porting bias) }\end{array}$ & Low risk & \begin{tabular}{l} 
All outcomes stated in protocol were reported \\
\hline
\end{tabular}
\end{tabular}

Whiteley 2012

\begin{tabular}{ll}
\hline Methods & $\begin{array}{l}\text { Country: USA } \\
\text { Randomisation: Computer-generated }\end{array}$ \\
\hline Participants & 330 women, mean age 44, mean CPD 17, FTND score $5.0,<20$ mins of vigorous activity twice a week \\
\hline Interventions & $\begin{array}{l}\text { (a) Intervention: } 12 \text { weeks YMCA membership, } 4 \text { individual personal training sessions over } 12 \text { weeks } \\
\text { (aerobic and resistance exercise) plus group-based CP (once a week for } 12 \text { weeks) }\end{array}$ \\
& (b) Control: 4 wellness sessions over 12 weeks) plus CP as (a) \\
& Interventions began before quit date \\
\hline Outcomes & Continuous abstinence \\
Validation: Saliva cotinine $<10$ mg $/ \mathrm{mL}$ \\
Follow-up: end of treatment, and 3, 6 months and 12 months post-treatment \\
Contact time balanced between (a) and (b) \\
Funding: This research was supported by the National Institute on Drug Abuse at the NIH (Grant \\
DA021729) \\
Conflicts of interest: None declared
\end{tabular}


Whiteley 2012 (Continued)

Risk of bias

\begin{tabular}{lll}
\hline Bias & Authors' judgement & Support for judgement \\
\hline $\begin{array}{l}\text { Random sequence genera- } \\
\text { tion (selection bias) }\end{array}$ & Low risk & Computer-generated \\
\hline $\begin{array}{l}\text { Allocation concealment } \\
\text { (selection bias) }\end{array}$ & Unclear risk & Not specified \\
\hline $\begin{array}{l}\text { Blinding of outcome as- } \\
\text { sessment (detection bias) } \\
\text { All outcomes }\end{array}$ & Low risk & $\begin{array}{l}\text { Details of blinding not specified, but as self-reports of smoking were validated } \\
\text { objectively by expired CO and saliva cotinine risk is considered as low }\end{array}$ \\
\hline $\begin{array}{l}\text { Incomplete outcome data } \\
\text { (attrition bias) }\end{array}$ & Low risk & ITT analysis \\
All outcomes & $78.5 \%$ followed up at 12 months, with similar follow-up in the 2 groups \\
\hline $\begin{array}{l}\text { Selective reporting (re- } \\
\text { porting bias) }\end{array}$ & Low risk & Smoking outcomes reported as described in Methods \\
\hline
\end{tabular}

BMI: body mass index; CBT: cognitive behavioural therapy; CO: carbon monoxide; CONT: control; CP: cessation programme; CPD: cigarettes per day; CV: cardiovascular; FTCD: Fagerström Test for Cigarette Dependence; FTND: Fagerström Test for Nicotine Dependence; FTQ: Fagerström Tolerance Questionnaire; HR: heart rate; INT: intervention; ITT: intention to treat; MVPA: moderate to vigorous physical activity; NRT: nicotine replacement therapy; $\mathrm{PP}(\mathrm{A})$ : point prevalence (abstinence); ppm: parts per million

Characteristics of excluded studies [ordered by study ID]

\begin{tabular}{|c|c|}
\hline Study & Reason for exclusion \\
\hline Abrantes 2017 & Acute study \\
\hline Abrantes 2018 & Acute study \\
\hline Aggarwal 2017 & Multiple component yoga intervention \\
\hline Al-Chalabi 2008 & $\begin{array}{l}\text { Follow-up less than } 6 \text { months and combined isometric exercise and body-scanning interventions; it } \\
\text { was not possible to assess the specific effects of exercise }\end{array}$ \\
\hline Al-Eisa 2016 & Non-randomised study \\
\hline Allen 2018a & Quit attempts rather than cessation as outcome \\
\hline Allen $2018 b$ & Acute study \\
\hline Angeli 2018 & Acute study \\
\hline Arbour-Nicitopoulos 2011 & Acute study. \\
\hline Audrain-McGovern 2015 & Acute study \\
\hline Bernard 2013 & Did not assess smoking abstinence. \\
\hline Blank 2017 & Follow-up less than 6 months \\
\hline
\end{tabular}




\begin{tabular}{|c|c|}
\hline Study & Reason for exclusion \\
\hline Bock 2012 & Multiple component yoga programme \\
\hline Caliani 2004 & $\begin{array}{l}\text { Included an exercise programme as part of a multiple-component smoking-cessation programme. } \\
\text { It was therefore not possible to examine the specific effects of exercise }\end{array}$ \\
\hline Chaney 2008 & Follow-up was less than 6 months \\
\hline Cinciripini 1996 & $\begin{array}{l}\text { Included an exercise programme as part of a multiple-component smoking-cessation programme. } \\
\text { It was therefore not possible to examine the specific effects of exercise }\end{array}$ \\
\hline Clark 2005 & A non-exercise control group was not included \\
\hline Conklin 2017 & Acute study \\
\hline Cooke 2016 & Acute study. \\
\hline Copeland 2006 & $\begin{array}{l}\text { Included an exercise programme as part of a multiple-component smoking-cessation programme. } \\
\text { It was therefore not possible to examine the specific effects of exercise }\end{array}$ \\
\hline Daley 2004 & Acute study \\
\hline Daniel 2004 & Acute study \\
\hline Daniel 2006 & Acute study \\
\hline Daniel 2007 & Acute study \\
\hline De Jesus 2014 & Acute study \\
\hline De Jesus 2018a & Acute study \\
\hline De Jesus 2018b & Follow-up was less than 6 months \\
\hline Elibero 2011 & Acute study. \\
\hline Everson 2006 & Acute study \\
\hline Everson 2008 & Acute study \\
\hline Faulkner 2010 & Acute study \\
\hline Fong 2014 & Acute study \\
\hline Fortmann 1995 & $\begin{array}{l}\text { Included an exercise programme as part of a multiple-component smoking-cessation programme. } \\
\text { It was therefore not possible to examine the specific effects of exercise }\end{array}$ \\
\hline Garcia 2019 & Multi-component intervention \\
\hline Gorini 2012 & Not all participants wished to quit \\
\hline Grove 1993 & The outcome was withdrawal symptoms rather than smoking abstinence \\
\hline Grove 2006 & Had sleep disturbance as the main outcome, rather than smoking abstinence \\
\hline Haasova 2011 & Acute study \\
\hline
\end{tabular}




\begin{tabular}{|c|c|}
\hline Study & Reason for exclusion \\
\hline Harper 2012 & Acute study \\
\hline Harper 2013 & Acute study \\
\hline Hassandra 2012 & Lack of a control group \\
\hline Hatzigeorgiadis 2016 & Acute study \\
\hline Ho 2014 & Acute study \\
\hline Horn 2011 & Included smokers not wishing to quit \\
\hline Hurt 1994 & $\begin{array}{l}\text { Included an exercise programme as part of a multiple-component smoking-cessation programme. } \\
\text { It was therefore not possible to examine the specific effects of exercise }\end{array}$ \\
\hline Hwang 2012 & A non-exercise control group was not included. Also follow-up was less than 6 months. \\
\hline Janse van Rensburg 2008 & Acute study \\
\hline Janse van Rensburg 2009a & Acute study \\
\hline Janse van Rensburg 2009b & Acute study \\
\hline Janse van Rensburg 2010 & Acute study \\
\hline Janse van Rensburg 2012 & Acute study \\
\hline Janse van Rensburg 2013 & Acute study \\
\hline Jones 2001 & $\begin{array}{l}\text { Included an exercise programme in a self-help manual as part of a multiple-component pro- } \\
\text { gramme. It was therefore not possible to examine the specific effects of exercise }\end{array}$ \\
\hline
\end{tabular}

Jonsdottir $2001 \quad \begin{aligned} & \text { A quasi-experimental study comparing a smoking cessation programme plus weekly group exer- } \\ & \text { cise with the smoking cessation programme only. Participants were not randomly allocated to the } \\ & \text { groups }\end{aligned}$

\begin{tabular}{ll}
\hline Katomeri 2007 & Acute study \\
\hline Kinnunen 2013 & Did not include a non-exercise condition \\
\hline Kovelis 2012 & Did not assess smoking abstinence. \\
\hline Kurti 2014a & Acute study \\
\hline Kurti 2014b & Acute study \\
\hline Leelarungrayub 2010 & Did not include smoking abstinence as an outcome \\
\hline Linke 2012 & Assessment of smoking abstinence less than 6 months \\
\hline Loprinzi 2015 & Cohort study \\
\hline Luo 2019 & Cohort study \\
\hline Mantoani 2014 & Lack of a control group \\
\hline
\end{tabular}




\begin{tabular}{|c|c|}
\hline Study & Reason for exclusion \\
\hline McClure 2009 & $\begin{array}{l}\text { Included exercise counselling as part of a multiple-component smoking-cessation programme. It } \\
\text { was therefore not possible to examine the specific effects of exercise }\end{array}$ \\
\hline McClure 2011 & $\begin{array}{l}\text { Included exercise counselling as part of a multiple risk factor intervention. It was therefore not pos- } \\
\text { sible to examine the specific effects of exercise on smoking cessation. }\end{array}$ \\
\hline Mclver 2004 & There was no control group \\
\hline Mikhail 1983 & Acute study \\
\hline Nair 2017 & Follow-up was less than 6 months \\
\hline Nguyen 2012 & $\begin{array}{l}\text { Included an exercise programme as part of a multiple-component smoking-cessation programme. } \\
\text { It was therefore not possible to examine the specific effects of exercise }\end{array}$ \\
\hline Oenema 2008 & $\begin{array}{l}\text { Included an exercise programme as part of a multiple-component smoking-cessation programme. } \\
\text { It was therefore not possible to examine the specific effects of exercise }\end{array}$ \\
\hline Oh 2014 & Acute study \\
\hline Ortega Sanchez-Pinilla 2006 & Retrospective study \\
\hline Pomerleau 1987 & Acute study \\
\hline Prapavessis 2014 & Acute study \\
\hline Priebe 2017 & Not an RCT \\
\hline Prochaska 2008 & $\begin{array}{l}\text { Included exercise counselling as part of a multiple-component relapse-prevention programme. It } \\
\text { was therefore not possible to examine the specific effects of exercise. Also, follow-up was less than } \\
6 \text { months }\end{array}$ \\
\hline
\end{tabular}

\begin{tabular}{ll}
\hline Ramsay 2004 & $\begin{array}{l}\text { Included an exercise programme as part of a multiple-component smoking-cessation programme. } \\
\text { It was therefore not possible to examine the specific effects of exercise }\end{array}$ \\
\hline Reeser 1983 & Acute study \\
\hline Reid 2014 & $\begin{array}{l}\text { Included an exercise programme as part of a multiple-component smoking-cessation programme. } \\
\text { It was therefore not possible to examine the specific effects of exercise }\end{array}$ \\
\hline Roberts 2015 & Acute study \\
\hline Saltychev 2012 & $\begin{array}{l}\text { Included an exercise programme as part of a multiple-component smoking-cessation programme. } \\
\text { It was therefore not possible to examine the specific effects of exercise }\end{array}$ \\
\hline Scerbo 2010 & Acute study \\
\hline Schneider 2015 & Acute study \\
\hline Spring 2004 & $\begin{array}{l}\text { Combined an exercise programme with a dietary intervention. It was therefore not possible to ex- } \\
\text { amine the specific effects of exercise }\end{array}$ \\
\hline Taylor 2005 & Acute study \\
\hline Taylor $2006 a$ & Acute study \\
\hline
\end{tabular}




\begin{tabular}{|c|c|}
\hline Study & Reason for exclusion \\
\hline Taylor 2006b & Acute study \\
\hline Taylor 2014 & Assessment of smoking abstinence less than 6 months. \\
\hline Thayer 1993 & Acute study \\
\hline Toobert 2011 & $\begin{array}{l}\text { Included an exercise programme as part of a multiple-component smoking-cessation programme. } \\
\text { It was therefore not possible to examine the specific effects of exercise }\end{array}$ \\
\hline Treviño 2014 & Not an RCT \\
\hline Trigwell 2014 & Non-randomised study \\
\hline Tritter 2015 & Acute study \\
\hline Ussher 2001 & Acute study \\
\hline Ussher 2006 & Acute study \\
\hline Ussher 2008 & Did not include a control group \\
\hline Ussher 2009 & Acute study \\
\hline Vander Weg 2008 & $\begin{array}{l}\text { Included an exercise programme as part of a multiple-component programme for smoking cessa- } \\
\text { tion and management of weight and blood pressure. It was therefore not possible to examine the } \\
\text { specific effects of exercise }\end{array}$ \\
\hline Vickers 2005 & The follow-up was less than 6 months \\
\hline Vickers 2009 & Follow-up was less than 6 months. \\
\hline Whiteley 2007 & Did not include a control group \\
\hline Williams 2010 & Follow-up was less than 6 months. \\
\hline Williams 2011 & Acute study \\
\hline Ybarra 2013 & Assessment of smoking abstinence less than 6 months \\
\hline Zwick 2006 & Unable to obtain details of study from authors \\
\hline
\end{tabular}

Characteristics of ongoing studies [ordered by study ID]

Ciccolo 2014

\begin{tabular}{ll}
\hline Trial name or title & Resistance training as an aid to smoking cessation treatment \\
\hline Methods & $\mathrm{RCT}$ \\
\hline Participants & $\mathrm{N}=206$ \\
\hline Interventions & Resistance training vs contact control \\
\hline
\end{tabular}


Ciccolo 2014 (Continued)

Outcomes

Smoking cessation, Follow-up assessments will occur at the end of the 12-weeks intervention, and at a 6-month and 12-month (post-randomisation) visit

Starting date

Study start date: 2013; estimated study completion date: March 2019

Contact information

Dr Joe Ciccolo, ciccolo@tc.columbia.edu

Notes

ClinicalTrials.gov Identifier: NCT01951456

NCT00921388

\begin{tabular}{ll}
\hline Trial name or title & Exercise for smoking cessation in postmenopausal women \\
\hline Methods & RCT \\
\hline Participants & $\mathrm{N}=364$ \\
\hline Interventions & $\begin{array}{l}\text { All participants receive smoking cessation counselling and varenicline, plus either (i) } 1 \text {-hour exer- } \\
\text { cise sessions twice a week for } 8 \text { weeks, then once a week for } 8 \text { weeks, then once every other week } \\
\text { for } 4 \text { weeks, or (ii) participants in the control group receive a relaxation programme that controls } \\
\text { for contact time }\end{array}$ \\
\hline
\end{tabular}

Outcomes Smoking abstinence at weeks 12 and 64

\begin{tabular}{ll}
\hline Starting date & Start date: March 2009; study completion Aug 2017; publication in preparation \\
\hline Contact information & Cheryl A Oncken \\
\hline Notes & ClinicalTrials.gov Identifier: NCT00921388 \\
\hline
\end{tabular}

\section{NCT02086149}

\begin{tabular}{ll}
\hline Trial name or title & Exercise for depressed smokers \\
\hline Methods & $\mathrm{RCT}$ \\
\hline Participants & $\mathrm{N}=250$ \\
\hline Interventions & $\begin{array}{l}\text { (a) } 12 \text {-week moderate-intensity behavioural exercise intervention. Weekly sessions with an exer- } \\
\text { cise physiologist who will also assign weekly exercise goals. 2-month course of the nicotine patch } \\
\text { initiated during week } 5\end{array}$ \\
\hline $\begin{array}{l}\text { (b) } 12 \text {-week health education control. Weekly sessions about 12 different topics related to the } \\
\text { health effects of smoking, led by an expert in smoking cessation }\end{array}$ \\
\hline Smoking cessation at 12 months, verified biochemically (saliva cotinine) \\
\hline Starting date & February 2014, estimated completion date: Feb 2019 \\
\hline Contact information & Dr Ana Abrantes, ana_abrantes@brown.edu \\
\hline
\end{tabular}


Pavey 2015

\section{Trial name or title}

Assessing the effectiveness of High Intensity Interval Training (HIIT) for smoking cessation in women

\begin{tabular}{ll}
\hline Methods & RCT \\
\hline Participants & Women aged 18 - 55 years who smoke $\geq 5$ CPD, and want to quit smoking \\
\hline Interventions & $\begin{array}{l}\text { All participants will receive usual care for quitting smoking. } \\
\text { Group } 1 \text { will complete } 2 \text { gym-based supervised HIIT sessions/week and } 1 \text { home-based HIIT ses- } \\
\text { sion/week. At each training session participants will be asked to complete } 4 \times 4 \text {-min intervals at ap- } \\
\text { proximately } 90 \% \text { of maximum heart rate interspersed with 3-min recovery periods } \\
\text { Group } 2 \text { participants will receive a resource pack and pedometer, and will be asked to use the } \\
\text { 10,000 steps log book to record steps and other physical activities. The aim will be to increase daily } \\
\text { steps to } 10,000 \text { steps/day }\end{array}$ \\
\hline Outcomes & $\begin{array}{l}\text { Identified using the Russell standard, self-reported abstinence (previous } 2 \text { weeks) and CO concen- } \\
\text { tration }<10 \text { ppm } 13 \text { and } 26 \text { weeks after randomisation }\end{array}$ \\
\hline Secondary outcome: CPD
\end{tabular}

\title{
Smits 2019
}

\section{Trial name or title}

YMCA exercise intervention to augment smoking cessation treatment in adults with high anxiety sensitivity: study protocol for a randomised controlled trial

\section{Methods}
"Building upon emerging evidence supporting the efficacy of exercise as an aid for smoking ces- sation in adults with high AS, we are conducting a trial to examine the efficacy and feasibility of this clinical application when implemented in a community setting. Partnering with the YMCA, this study aims to enroll 150 adults in a standard smoking cessation protocol (i.e. counselling and nico- tine replacement therapy) and randomly assign them to either 15 weeks of programmed vigor- ous-intensity or low-intensity exercise. Smoking abstinence data will be collected up to 6 months following the quit attempt."

\section{Participants}

\author{
Interventions
}

\section{Outcomes}

\section{Starting date}

Contact information Smits JAJ

\section{Notes}


Tai-Hing 2016

\begin{tabular}{ll}
\hline Trial name or title & Short-bout Handgrip Exercise for Smoking Cessation (SHESC) \\
\hline Methods & $\begin{array}{l}\text { All the participants will be randomised to one of the RCT groups by using sequentially numbered, } \\
\text { opaque sealed envelope method. Participants from both groups will be helped to install a phone } \\
\text { application (App) in their smart phone which can send reminders of doing exercise or healthy diet. } \\
\text { Also, the participants will enter their smoking and craving data by the App by answering the auto- } \\
\text { matic daily questionnaire. Telephone follow-up will be conducted at 2, } 6 \text { and } 12 \text { months }\end{array}$ \\
\hline Participants & $\begin{array}{l}\text { Adults who enrolled in smoking cessation service, smoke 10 CPD+ and interested in participating in } \\
\text { an exercise/diet programme for smoking cessation }\end{array}$ \\
\hline Interventions & Short-bout exercise (intervention) and healthy diet (control) \\
\hline Outcomes & Primary outcome measures: \\
4-week self-reported tobacco abstinence at 6-month follow-up \\
Telephone follow-up will be conducted at 2, 6 and 12 months \\
\hline Starting date & October 2016 \\
\hline Notes & Tai Hing Lam \\
\hline
\end{tabular}

\section{Vander Weg 2018}

$\begin{array}{ll}\text { Trial name or title } & \begin{array}{l}\text { Community-based physical activity as adjunctive smoking cessation treatment: Rationale, design, } \\ \text { and baseline data for the Lifestyle Enhancement Program (LEAP) randomized controlled trial }\end{array}\end{array}$

\begin{tabular}{ll}
\hline Methods & $\begin{array}{l}\text { 2-group, randomised controlled trial. Adult smokers were randomly assigned to treatment condi- } \\
\text { tions }\end{array}$ \\
\hline Participants & $\begin{array}{l}\text { Participants consist of } 392 \text { sedentary smokers (mean (standard deviation) age }=44.6 \text { (10.2) years; } \\
62 \% \text { female; 31\% African-American). }\end{array}$ \\
\hline Interventions & $\begin{array}{l}\text { Treatment conditions consisted of an individualised physical activity intervention delivered by } \\
\text { health fitness instructors in community-based exercise facilities or an equal contact wellness con- } \\
\text { trol. All participants received standard cognitive behavioural smoking cessation counselling com- } \\
\text { bined with nicotine replacement therapy }\end{array}$ \\
\hline Outcomes & $\begin{array}{l}\text { The primary outcomes are 7-day PPA at 7 weeks, } 6 \text { and } 12 \text { months. } \\
\text { Secondary outcomes include self-reported physical activity, dietary intake, BMI, waist circumfer- } \\
\text { ence, percent body fat, and nicotine withdrawal symptoms }\end{array}$ \\
\hline Starting date & \\
\hline Notes & \\
\hline
\end{tabular}

BMI: body mass index; CPD: cigarettes per day; ppm: parts per million 


\section{DATA AND ANALYSES}

\section{Comparison 1. Exercise component versus smoking cessation programme only}

\begin{tabular}{|c|c|c|c|c|}
\hline Outcome or subgroup title & $\begin{array}{l}\text { No. of } \\
\text { studies }\end{array}$ & $\begin{array}{l}\text { No. of } \\
\text { partici- } \\
\text { pants }\end{array}$ & Statistical method & Effect size \\
\hline $\begin{array}{l}1 \text { Smoking abstinence at longest } \\
\text { follow-up, subgroup by exercise } \\
\text { type }\end{array}$ & 21 & 6607 & Risk Ratio (M-H, Random, 95\% Cl) & $1.08[0.96,1.22]$ \\
\hline 1.1 Cardiovascular exercise & 17 & 3635 & Risk Ratio (M-H, Random, 95\% Cl) & $1.08[0.94,1.24]$ \\
\hline 1.2 Resistance training & 1 & 25 & Risk Ratio (M-H, Random, 95\% Cl) & $1.85[0.19,17.84]$ \\
\hline 1.3 Cardiovascular and resistance & 1 & 330 & Risk Ratio (M-H, Random, 95\% Cl) & $1.81[0.69,4.78]$ \\
\hline 1.4 Not specified & 2 & 2617 & Risk Ratio (M-H, Random, 95\% Cl) & $1.05[0.84,1.32]$ \\
\hline $\begin{array}{l}2 \text { Relapse prevention at longest } \\
\text { follow-up }\end{array}$ & 2 & 453 & Risk Ratio (M-H, Random, 95\% Cl) & $0.98[0.65,1.47]$ \\
\hline
\end{tabular}

Analysis 1.1. Comparison 1 Exercise component versus smoking cessation programme only, Outcome 1 Smoking abstinence at longest follow-up, subgroup by exercise type.

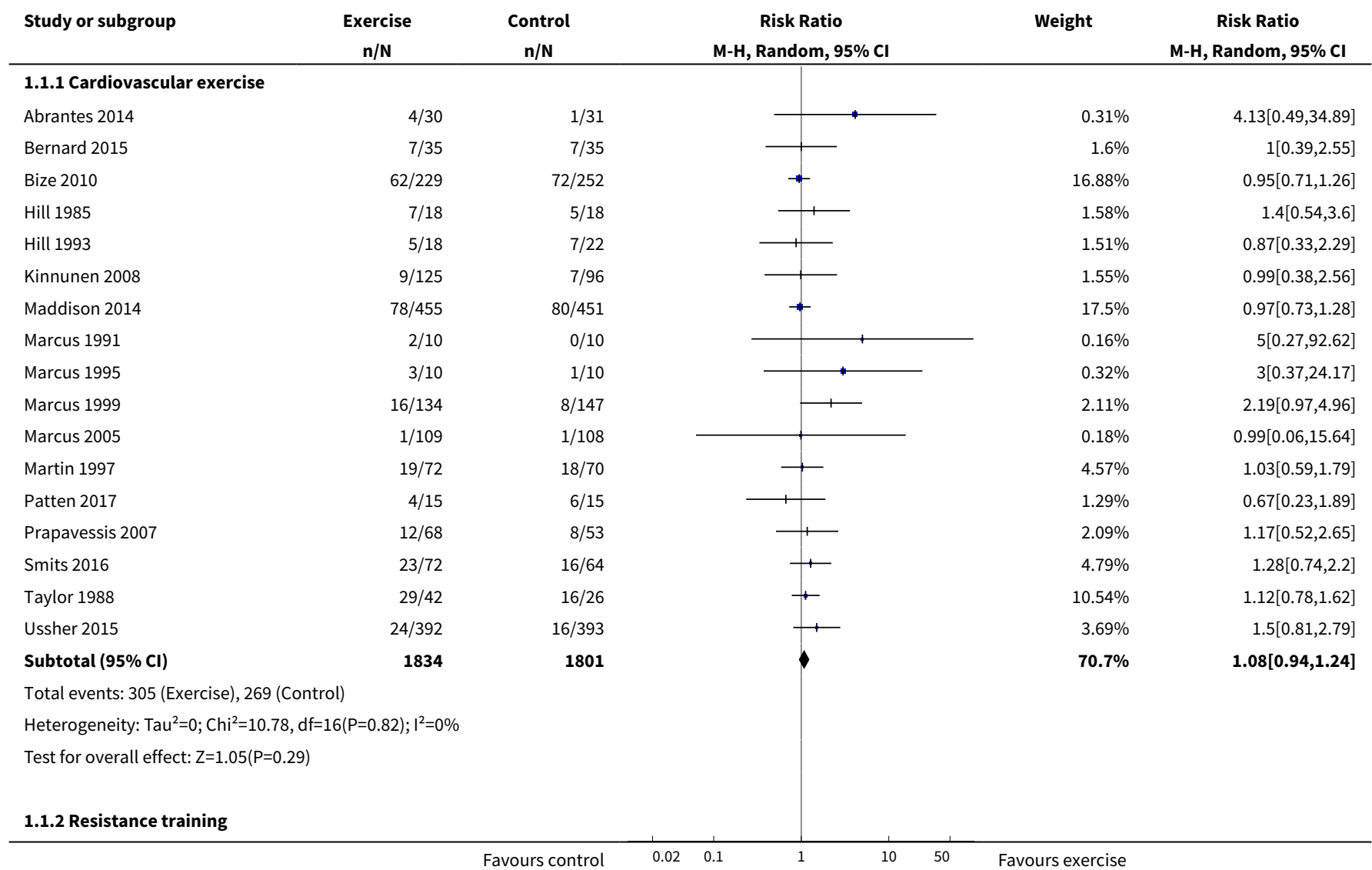




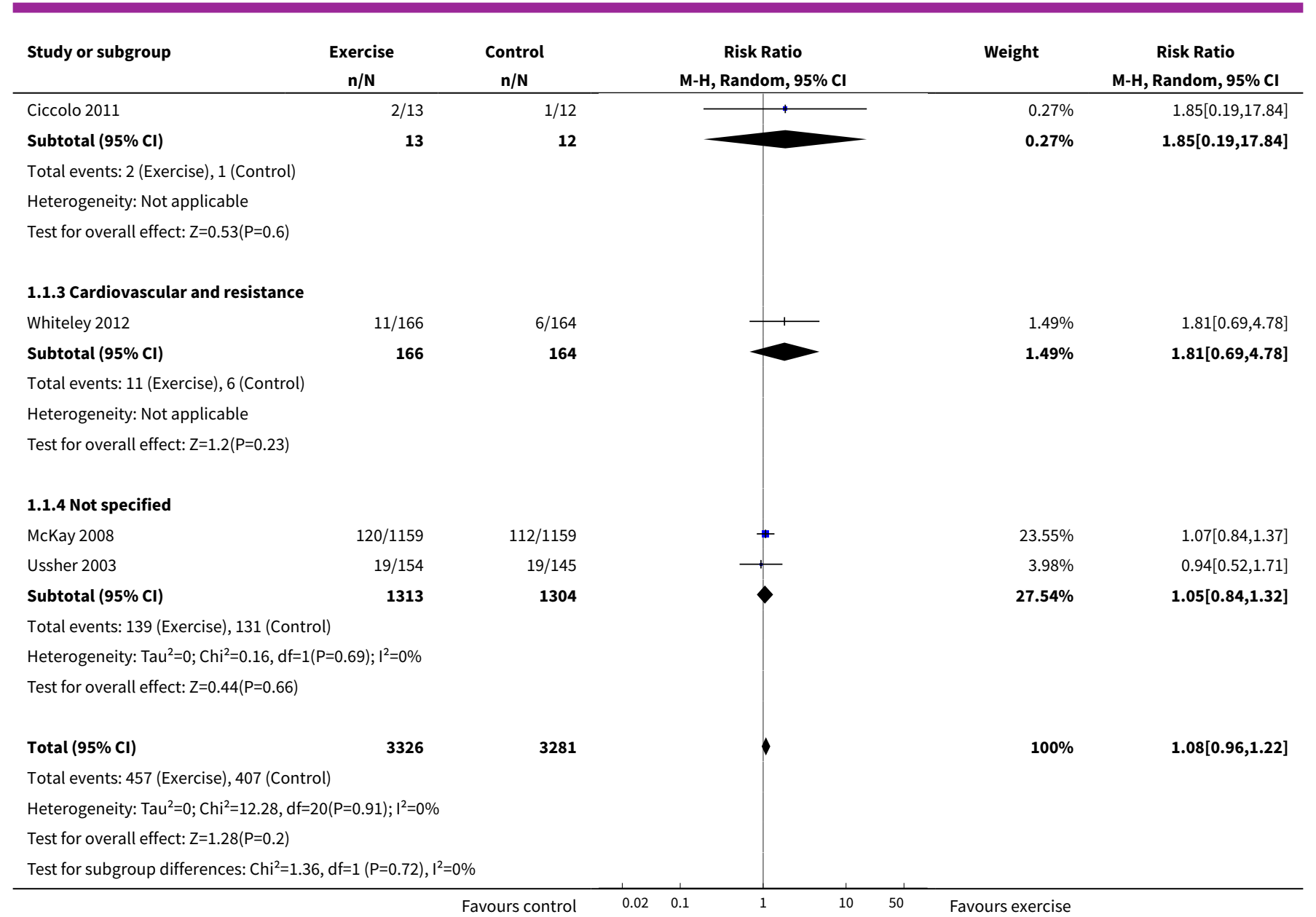

Analysis 1.2. Comparison 1 Exercise component versus smoking cessation programme only, Outcome 2 Relapse prevention at longest follow-up.

\begin{tabular}{|c|c|c|c|c|c|}
\hline Study or subgroup & $\begin{array}{c}\text { Exercise } \\
\mathrm{n} / \mathrm{N}\end{array}$ & $\begin{array}{c}\text { Control } \\
n / N\end{array}$ & $\begin{array}{c}\text { Risk Ratio } \\
\text { M-H, Random, } 95 \% \mathrm{Cl}\end{array}$ & Weight & $\begin{array}{c}\text { Risk Ratio } \\
\text { M-H, Random, } 95 \% \mathrm{Cl}\end{array}$ \\
\hline Hassandra 2017 & $9 / 25$ & $7 / 19$ & $\longrightarrow$ & $26.86 \%$ & $0.98[0.44,2.15]$ \\
\hline Prapavessis 2016 & $30 / 214$ & $28 / 195$ & & $73.14 \%$ & $0.98[0.61,1.57]$ \\
\hline Total $(95 \% \mathrm{Cl})$ & 239 & 214 & & $100 \%$ & $0.98[0.65,1.47]$ \\
\hline \multicolumn{6}{|c|}{ Total events: 39 (Exercise), 35 (Control) } \\
\hline Test for overall effect & & & & & \\
\hline
\end{tabular}

WHAT'S NEW

\begin{tabular}{lll}
\hline Date & Event & Description \\
\hline 8 June 2019 & New search has been performed & $\begin{array}{l}6 \text { new studies added, several excluded studies added, all of main } \\
\text { text updated, 'Risk of bias' table updated, meta-analysis added. }\end{array}$ \\
\hline
\end{tabular}




\begin{tabular}{lll}
\hline Date & Event & Description \\
\hline & $\begin{array}{l}\text { We have removed the table of acute studies, and instead provide } \\
\text { a narrative summary }\end{array}$ \\
\hline 8 June 2019 & $\begin{array}{l}\text { New citation required but conclusions } \\
\text { have not changed }\end{array}$ & No change to conclusions \\
\hline
\end{tabular}

\section{HISTORY}

Review first published: Issue 3, 2000

\begin{tabular}{lll}
\hline Date & Event & Description \\
\hline 30 November 2011 & $\begin{array}{l}\text { New citation required but conclusions } \\
\text { have not changed }\end{array}$ & New citation for update \\
\hline 26 September 2011 & New search has been performed & $\begin{array}{l}\text { Two new studies added, several excluded studies added, all of } \\
\text { main text updated, several studies added to appendix of acute } \\
\text { studies. }\end{array}$ \\
\hline
\end{tabular}

\begin{tabular}{lll}
\hline 21 July 2008 & New search has been performed & $\begin{array}{l}\text { Two new studies included, several excluded studies added, back- } \\
\text { ground updated, table of acute studies added. }\end{array}$ \\
\hline 21 July 2008 & $\begin{array}{l}\text { New citation required but conclusions } \\
\text { have not changed }\end{array}$ & Change of authorship \\
\hline 1 July 2008 & Amended & Converted to new review format. \\
\hline 22 May 2005 & New search has been performed & Three new studies, no change to conclusions. \\
\hline 19 May 2002 & New search has been performed & Search updated, no new studies. \\
\hline
\end{tabular}

\section{CONTRIBUTIONS OFAUTHORS}

The original review was conceived, extracted and written by Michael Ussher (MU), Adrian Taylor (AT), Robert West (RW) and Andrew McEwen (AM).

The idea for the review was conceived by MU, AT and RW. MU was responsible for co-ordinating the review and undertook the search process and data management, including screening search results and retrieved papers, abstracting data from the papers and contacting study authors for additional information.

All review authors made a contribution to the design, search strategy and interpretation of data. The writing of the original review was led by MU with assistance from RW, AT and AM.

The 2005 update was conducted solely by MU.

We updated the 2008 review to include a table of studies examining the acute effects of exercise on cravings and withdrawal symptoms. AT and Guy Faulkner (GF) synthesised this evidence, in both 2008 and 2011.

In both the 2008 and 2011 reviews MU added studies to the main review and these details were checked by GF. In both 2008 and 2011 , except for the section 'Acute effect of exercise on tobacco withdrawal and cravings' (which was updated by AT), MU updated the text and other review authors checked it.

In the 2014 review MU added studies to the main review and to the table of acute studies, and revised the text. In 2014 we added a table of studies (Appendix 2) assessing the effect of exercise interventions on cigarette consumption. AT or GF checked all the revisions and additions against the original papers. Both AT and GF checked all the revisions to the main text. 
In 2019 Jonathan Livingstone-Banks searched the Cochrane Tobacco Addiction Group register and KA conducted the rest of the searches. MU, AT, GF and KA were involved with independently checking titles, abstracts and full texts for relevant studies, with two review authors checking all the titles retrieved from the searches. MU, AT, GF and KA were involved with extracting study data and a second review author checked the entries. Two review authors independently conducted risk assessments for each study and discussed and resolved any differences. MU and Jamie Hartmann-Boyce (JHB) revised the text, and all review authors checked and commented on the revisions.

\section{DECLARATIONS OF INTEREST}

MU: was involved in the conduct of four of the included studies (Ciccolo 2011; Patten 2017; Ussher 2003; Ussher 2015).

AT: was involved with three of the included trials (Bernard 2015; Ussher 2003; Ussher 2015).

GF: was involved with one of the included trials (Prapavessis 2016).

JHB: none declared.

KA: none declared.

\section{SOURCES OF SUPPORT}

\section{Internal sources}

- St George's, University of London, UK.

- University of Exeter, UK.

- University of Toronto, Canada.

- University of Stirling, UK.

\section{External sources}

- National Institute for Health Research (NIHR) Cochrane Incentive Award, UK.

\section{DIFFERENCES BETWEEN PROTOCOLAND REVIEW}

For the 2019 review we removed the table of studies assessing the acute effect of exercise on tobacco withdrawal and cravings, as these studies are not central to the review and are presented in other reviews.

\section{INDEX TERMS}

\section{Medical Subject Headings (MeSH)}

Cognitive Behavioral Therapy; Exercise; Randomized Controlled Trials as Topic; Recurrence; Smoking [psychology] [therapy]; Smoking Cessation [ ${ }^{*}$ methods]; Weight Gain

\section{MeSH check words}

Humans 